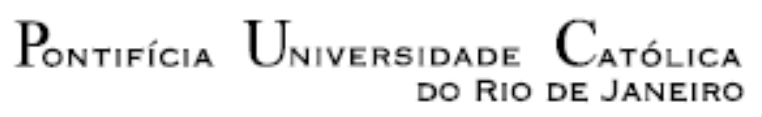

Patricia Isabel Pontón Bravo

Co-precipitation synthesis of Y2W3012 and Al2W3012 submicronic powders and their application in polymer matrix composites

Tese de Doutorado

Thesis presented to the Programa de PósGraduação em Engenharia de Materiais e de Processos Químicos e Metalúrgicos of PUC-Rio in partial fulfillment of the requirements for the degree of Doutor em Ciências - Engenharia de Materiais e de Processos Químicos e Metalúrgicos.

Advisor: Prof. Bojan Marinkovic

Rio de Janeiro

January 2017 


\section{Co-precipitation synthesis of Y2W3012 and Al2W3012 submicronic powders and their application in polymer matrix composites}

Thesis presented to the Programa de Pós-graduação em Engenharia de Materiais e de Processos Químicos e Metalúrgicos of PUC-Rio in partial fulfillment of the requirements for the degree of Doutor em Ciências Engenharia de Materiais e de Processos Químicos e Metalúrgicos. Approved by the undersigned Examination Committee.

Prof. Bojan Marinkovic Advisor Departamento de Engenharia Química e de Materiais - PUC-Rio

Profa. Ivani de Souza Bott Departamento de Engenharia Química e de Materiais - PUC-Rio

Profa. Sonia Letichevsky Departamento de Engenharia Química e de Materiais - PUC-Rio

Profa. Paula Mendes Jardim UFRJ

Prof. Roberto De Oliveira Magnago UniFOA

Prof. Márcio da Silveira Carvalho

Vice Dean of Graduate Studies Centro Técnico Científico - PUC-Rio

Rio de Janeiro, January 31st, 2017. 
All rights reserved.

\section{Patricia Isabel Pontón Bravo}

Majored in Chemical Engineering at Escuela Politécnica Nacional (Quito-Ecuador, 2009). She obtained her Master's degree in 2013 at PUC-Rio. She had experience in the synthesis of titanate-based nanostructures, materials with low positive, negative and near zero thermal expansion, as well as, in manufacturing of polymer matrix composites.

Bibliographic data

Pontón Bravo, Patricia Isabel

Co-precipitation synthesis of $\mathrm{Y} 2 \mathrm{~W} 3 \mathrm{O} 12$ and Al2W3O12 submicronic powders and their application in polymer matrix composites / Patricia Isabel Pontón Bravo; advisor: Bojan Marinkovic. - 2017.

119 f. : il. color. ; $30 \mathrm{~cm}$

Tese (doutorado)-Pontifícia Universidade Católica do Rio de Janeiro, Departamento de Engenharia Química e de Materiais, 2017. Inclui bibliografia

1. Engenharia de Materiais - Teses. 2. Engenharia Química - Teses. 3. Expansão térmica negativa. 4. Coprecipitação. 5. Aglomeração. 6. Compósitos de matriz polimérica. I. Marinkovic, Bojan. II. Pontifícia Universidade Católica do Rio de Janeiro. Departamento de Engenharia Química e de Materiais. III. Título. 
A mi abuelita Isabel, a mis amados padres Livia y Elicio, a mi hermano David, a mi amado esposo Marco. 


\section{Acknowledgments}

I would like to express my sincere gratitude to my advisor Prof. Bojan Marinkovic for his guidance, his patience, encouragement and continuous support during these past four years. I am also thankful for the confidence in my abilities and for the excellent example he has provided as a successful researcher and professor.

I have had the opportunity to work with the best lab-mates and friends: Margarita Habran, Juliana Viol, Juliana Resende, Gabriella Faro, Rafaela Carvalho, Anja Dosen and Luciana Prisco. The overall atmosphere in Photocatalysis Lab created by all of them has made my stay at PUC pleasant and enjoyable. I would like to express my sincere appreciation especially to Luciana Prisco for the friendship, time, ideas, enlightening discussions and teamwork during the last four years.

I would also like to thank everyone who contributes to the performing of different analyses and characterization techniques: Yuri Nascimento, Henrique Chayin, Carlos Queiroz, Antonio Mario Costa, Antonio Gutierrez, Marco Antonio S. Abreu, Edisson Morgado, Prof. Ricardo Queiroz Aucélio, Prof. Omar Pandoli, Prof. Daniella Mulinari and Prof. Sonia Letichevsky.

I would like to thank my friends of Fatigue Lab: Julián, Giancarlo, Jorge, Victor, Jesús, Felipe and prof. José L. Freire, as well as, my friends from PUCRio: Lilia, Maria Isabel, Daniel and Khrissy. I am especially indebted to my friends from Ecuador: Salito, Gaby, Evelyn, Sofy, Dorita for all the encouraging messages. Thanks Gaby for keeping in touch during the last six years, for demonstrating me that true friendship is stronger than the barriers of time and distance.

I gratefully acknowledge the funding sources that made this work possible. I would like to thank CNPq and FAPERJ for the scholarships, as well as, to U. S. Army for the financial support of my research.

Lastly, I would like to thank my family for all their love and encouragement. My mother Livia, my father Elicio, my brother David and my aunt Luz taught me that true love never gives up and overcomes all the barriers of 
distance. Most of all I would like to thank my loving, supportive, inspiring and patient husband Marco, whose smile makes my day wonderful despite the obstacles. I would like to thank God for the joy of being alive and for allowing me to share my life with the people I love most 


\section{Abstract}

Pontón Bravo, Patricia Isabel; Marinkovic, Bojan (Advisor). Coprecipitation synthesis of Y2W3O12 and Al2W3O12 submicronic powders and their application in polymer matrix composites. Rio de Janeiro, 2017. 119p. Tese de Doutorado - Departamento de Engenharia Química e de Materiais, Pontifícia Universidade Católica do Rio de Janeiro.

The aim of this work was to synthesize $\mathrm{Al}_{2} \mathrm{~W}_{3} \mathrm{O}_{12}$ and $\mathrm{Y}_{2} \mathrm{~W}_{3} \mathrm{O}_{12}$ submicronic powders and study the effect of incorporation of these fillers on thermal expansion coefficient (CTE) and mechanical properties of high density polyethylene (HDPE) composites. $\mathrm{Y}_{2} \mathrm{~W}_{3} \mathrm{O}_{12}$ was synthesized via co-precipitation by mixing reactants and modified reverse strike co-precipitation, to assess the influence of the method on agglomeration degree of powders. Both methods produced $\mathrm{Y}_{2} \mathrm{~W}_{3} \mathrm{O}_{12}$ submicronic powders $(0.60-0.70 \mu \mathrm{m})$, with similar primary particle sizes and agglomeration degrees, as verified by different characterization techniques. $\mathrm{Al}_{2} \mathrm{~W}_{3} \mathrm{O}_{12}$ was synthesized via co-precipitation by mixing reactants and normal strike method, using two distinct tungsten sources and the assynthesized precursors were microwave dryied. The effects of synthesis $\mathrm{pH}$ (4.2 and 6.0) on final agglomeration state of the as-synthesized powders were assessed. $\mathrm{Al}_{2} \mathrm{~W}_{3} \mathrm{O}_{12}$ submicronic powders $(0.22-0.87 \mu \mathrm{m})$ were synthesized by these routes. Co-precipitation by mixing reactants at $\mathrm{pH}=4.2$ led to $\mathrm{Al}_{2} \mathrm{~W}_{3} \mathrm{O}_{12}$ powders with smaller agglomerate sizes $(\sim 0.22 \mu \mathrm{m})$. HDPE composites were manufactured by micro-compounding, using $\mathrm{Al}_{2} \mathrm{~W}_{3} \mathrm{O}_{12}$ and $\mathrm{Y}_{2} \mathrm{~W}_{3} \mathrm{O}_{12}$ powders with similar particle sizes $(\sim 0.70 \mu \mathrm{m})$, at volume fractions in the range of $0.001-0.011$. $\mathrm{HDPE} / \mathrm{Y}_{2} \mathrm{~W}_{3} \mathrm{O}_{12}$ composites presented CTE reductions of 20-25\% compared to neat $\mathrm{HDPE}$, in the temperature range of $25-70{ }^{\circ} \mathrm{C}$, while $\mathrm{HDPE} / \mathrm{Al}_{2} \mathrm{~W}_{3} \mathrm{O}_{12}$ composites displayed reductions on CTE of 7-8\%. Young's moduli of composites were increased 11-32\% and 8-21\% when filled with $\mathrm{Y}_{2} \mathrm{~W}_{3} \mathrm{O}_{12}$ and $\mathrm{Al}_{2} \mathrm{~W}_{3} \mathrm{O}_{12}$, respectively, whilst thermal stability of HDPE was preserved for all composites.

\section{Keywords}

Negative Thermal Expansion; Co-precipitation; Agglomeration; Polymer matrix composites. 


\section{Resumo}

Pontón Bravo, Patricia Isabel; Marinkovic, Bojan. Síntese de pós submicrônicos de Y2W3O12 e Al2W3012 pelo método de coprecipitação e a sua aplicação em compósitos de matriz polimérica. Rio de Janeiro, 2017. 119p. Tese de Doutorado - Departamento de Engenharia Química e de Materiais, Pontifícia Universidade Católica do Rio de Janeiro.

$\mathrm{O}$ objetivo deste trabalho foi sintetizar pós submicrônicos de $\mathrm{Y}_{2} \mathrm{~W}_{3} \mathrm{O}_{12} \mathrm{e}$ $\mathrm{Al}_{2} \mathrm{~W}_{3} \mathrm{O}_{12}$ visando estudar o efeito da incorporação destas cargas no coeficiente de expansão térmica (CET) e nas propriedades mecânicas de compósitos de polietileno de alta densidade (PEAD). As partículas de $\mathrm{Y}_{2} \mathrm{~W}_{3} \mathrm{O}_{12}$ foram obtidas pelos métodos de coprecipitação por mistura de reagentes e coprecipitação reversa modificada, com o intuito de avaliar a influência destas rotas no grau de aglomeração dos pós preparados. Ambos os métodos permitiram obter pós submicrônicos de $\mathrm{Y}_{2} \mathrm{~W}_{3} \mathrm{O}_{12}(0.6-0.7 \mu \mathrm{m})$ com tamanhos de partículas primárias e graus de aglomeração semelhantes, conforme verificado por diversas técnicas de caracterização. As partículas de $\mathrm{Al}_{2} \mathrm{~W}_{3} \mathrm{O}_{12}$ foram sintetizadas pelos métodos de coprecipitação por mistura de reagentes e coprecipitação normal, utilizando duas fontes de tungstênio e os precursores obtidos foram secos no micro-ondas. Os efeitos do pH da síntese (4.2 e 6.0) no estado de aglomeração dos pós sintetizados foram avaliados. Pós submicrônicos de $\mathrm{Al}_{2} \mathrm{~W}_{3} \mathrm{O}_{12}(0.22-0.87 \mu \mathrm{m})$ foram produzidos utilizando estas rotas. A coprecipitação pela mistura de reagentes em $\mathrm{pH}=4.2$ permitiram obter pós com aglomerados de menor tamanho $(\sim 0.22 \mu \mathrm{m})$. Os compósitos de PEAD foram fabricados por microextrusão-microinjeção, com partículas de $\mathrm{Al}_{2} \mathrm{~W}_{3} \mathrm{O}_{12}$ e $\mathrm{Y}_{2} \mathrm{~W}_{3} \mathrm{O}_{12}(\sim 0.70 \mu \mathrm{m})$ em frações volumétricas na faixa de 0.001-0.011. Os compósitos $\mathrm{PEAD} / \mathrm{Y}_{2} \mathrm{~W}_{3} \mathrm{O}_{12}$ exibiram reduções no CET de 20-25\% quando comparados ao PEAD na faixa de $25-70{ }^{\circ} \mathrm{C}$, enquanto os compósitos $\mathrm{PEAD} / \mathrm{Al}_{2} \mathrm{~W}_{3} \mathrm{O}_{12}$ mostraram reduções no CET de 7-8 \%. O módulo de Young aumentou 11-32\% e 8-21\% para os compósitos reforçados com $\mathrm{Y}_{2} \mathrm{~W}_{3} \mathrm{O}_{12}$ e $\mathrm{Al}_{2} \mathrm{~W}_{3} \mathrm{O}_{12}$, respectivamente, enquanto a estabilidade térmica do PEAD foi preservada para todos os compósitos.

\section{Palavras-chave}

Expansão térmica negativa; coprecipitação; aglomeração; compósitos de matriz polimérica. 


\section{Table of contents}

$\begin{array}{lr}\text { 1. Introduction } & 19\end{array}$

2. Literature review 21

2.1. Fundamentals of thermal expansion 21

2.2. NTE arising from transverse vibrations 22

2.3. Families of thermomiotics applied in polymer-based composites 24

2.4. Synthesis of thermomiotics by co-precipitation 26

2.4.1. Basic principles of co-precipitation 27

2.4.2. Types of co-precipitation method 29

2.5. State of agglomeration of ceramic powders 31

2.5.1. Factors influencing the agglomeration state of ceramic powders 34

2.5.2. Drying techniques of precursors 37

2.6. Polymer-based composites 39

2.6.1. Applications of thermomiotics in polymer matrix composites 39

2.6.2. Micromechanical models for prediction of CTE of polymerbased composites

3. Objectives 45

3.1. General objective 45

3.2. Specific objectives 45

4. A study of co-precipitation methods for the synthesis of $\mathrm{Y}_{2} \mathrm{~W}_{3} \mathrm{O}_{12}$ submicronic powders $\quad 46$

4.1. Background 46

4.2. Materials and methods 47

4.2.1. Co-precipitation of $\mathrm{Y}_{2} \mathrm{~W}_{3} \mathrm{O}_{12}$ by mixing reactants 47

4.2.2. Co-precipitation of $\mathrm{Y}_{2} \mathrm{~W}_{3} \mathrm{O}_{12}$ by modified reverse strike co- 
precipitation

4.2.3. Characterization of $\mathrm{Y}_{2} \mathrm{~W}_{3} \mathrm{O}_{12}$ amorphous precursors and calcined powders

4.2.4. Characterization of $\mathrm{Y}_{2} \mathrm{~W}_{3} \mathrm{O}_{12}$ bulk ceramic 50

4.3. Results and discussions 50

4.3.1. Co-precipitation of the amorphous precursors and their chemical composition

4.3.2. Crystal system of hydrated $\mathrm{Y}_{2} \mathrm{~W}_{3} \mathrm{O}_{12}$ and the bulk thermal expansions of $\mathrm{Y}_{2} \mathrm{~W}_{3} \mathrm{O}_{12}$ exposed to different drying conditions 55

4.3.3. Effects of co-precipitation methods on agglomeration of calcined $\mathrm{Y}_{2} \mathrm{~W}_{3} \mathrm{O}_{12}$ powders

4.4. Conclusions

5. Effects of the synthesis conditions on the agglomeration state of $\mathrm{Al}_{2} \mathrm{~W}_{3} \mathrm{O}_{12}$ submicronic powders prepared by co-precipitation method

5.1. Background

5.2. Materials and methods

5.2.1. Co-precipitation by mixing reactants 64

5.2.2. Normal strike co-precipitation 65

5.2.3. Characterization of $\mathrm{Al}_{2} \mathrm{~W}_{3} \mathrm{O}_{12}$ precursors and powders 66

5.3. Results and discussions 66

5.3.1. Co-precipitation of $\mathrm{Al}_{2} \mathrm{~W}_{3} \mathrm{O}_{12}$ amorphous precursors using two tungsten sources

5.3.2. Composition of the amorphous precursors 68

5.3.3. Crystallization temperature of as-synthesized precursors $\quad 70$

5.3.4. Effect of synthesis $\mathrm{pH}$ on zeta potential of as-synthesized $\begin{array}{ll}\text { precursors } & 72\end{array}$

5.3.5. Agglomeration state of $\mathrm{Al}_{2} \mathrm{~W}_{3} \mathrm{O}_{12}$ powders 75

5.3.6. Conclusions 79

6. Role of $A_{2} M_{3} \mathrm{O}_{12}$ submicronic fillers in improving thermal expansion behavior and mechanical properties of HDPE-based 
composites

6.1. Background 80

6.2. Materials and methods 80

6.2.1. Synthesis of $A_{2} M_{3} O_{12}$ submicronic fillers 80

6.2.2. Manufacturing of $\mathrm{HDPE} / \mathrm{A}_{2} \mathrm{M}_{3} \mathrm{O}_{12}$ composites 81

6.2.3. Characterization of $\mathrm{HDPE} / \mathrm{A}_{2} \mathrm{M}_{3} \mathrm{O}_{12}$ composites 82

6.3. Results and discussion 82

6.3.1. Thermal expansion behavior of $\mathrm{HDPE} / \mathrm{A}_{2} \mathrm{M}_{3} \mathrm{O}_{12}$ composites 82

6.3.2. Thermal stability of $\mathrm{HDPE} / \mathrm{A}_{2} \mathrm{M}_{3} \mathrm{O}_{12}$ composites 89

6.3.3. Mechanical properties of $\mathrm{HDPE} / \mathrm{A}_{2} \mathrm{M}_{3} \mathrm{O}_{12}$ composites 91

6.4. Conclusions 92

7. Conclusions and future works 94

$\begin{array}{lll}\text { 8. } & \text { References } & 97\end{array}$ 


\section{List of Figures}

Figure 2.1- Graph of potential energy versus interatomic distance, illustrating the increase in interatomic separation with rising temperature. $E_{i}$ is the energy level and $r_{i}$ is the corresponding interatomic distance [9].............................21

Figure 2.2- Longitudinal and transverse vibrations for the $\mathrm{M}-\mathrm{O}_{-} \mathrm{M}$ linkage [8]

Figure 2.3- $\mathrm{Y}_{2} \mathrm{MO}_{3} \mathrm{O}_{12}$ open-framework structure at room temperature, corner-sharing $\mathrm{YO}_{6}$ octahedra and $\mathrm{MO}_{4}$ thetrahedra [11].

Figure 2.4- Schemes of vibrational modes giving rise to NTE: (a) transverse vibrations of an oxygen atom in the $\mathrm{M}-\mathrm{O}-\mathrm{M}$ linkage and (b) cooperative rocking motion of polyhedra responsible for the shrinkage of $\mathrm{M}$----M distance [12].

Figure 2.5- Crystal structure of $\mathrm{ZrW}_{2} \mathrm{O}_{8}$, where $\mathrm{ZrO}_{6}$ octahedra are pale grey and $\mathrm{WO}_{4}$ tetrahedral are grey [14]

Figure 2.6- Differences between types of co-precipitation methods [30].

Figure 2.7- Scheme of different levels of agglomeration of ceramic powders, adapted from [35].

Figure 2.8- Scattering of light from large and small particles [37]. 33

Figure 2.9- Schematic representation of the hydrodynamic diameter of particles (Z-average value from intensity distribution) measured by DLS, adapted from [43].

Figure 2.10- (a) Water washed $\mathrm{Zr}(\mathrm{OH})_{4}$ gels and (b) ethanol-washed zirconia gels [47].

Figure 2.11- (a) Illustration of capillary forces bringing particles close to each other and (b) liquid or gas bridges giving rise to capillary walls [50].

Figure 2.12- Growth of ice inside the precursor gel, pushing primary particles apart [45] 
Figure 2.13- Scheme of an expansion mechanism caused by vapor within wet agglomerates during microwave drying.

Figure 4.1- Schematic representation of the synthesis of $\mathrm{Y}_{2} \mathrm{~W}_{3} \mathrm{O}_{12}$ through co-precipitation by mixing reactants.

Figure 4.2- Schematic representation of the synthesis of $\mathrm{Y}_{2} \mathrm{~W}_{3} \mathrm{O}_{12}$ by modified reverse strike co-precipitation.

Figure 4.3- Variation of the $\mathrm{pH}$ during the modified reverse strike coprecipitation of $\mathrm{Y}_{2} \mathrm{~W}_{3} \mathrm{O}_{12}$ precursor (dripping speed of yttrium nitrate solution: 2-3 $\mathrm{mLmin}^{-1}$ ).

Figure 4.4- DSC curves of the as-prepared $\mathrm{Y}_{2} \mathrm{~W}_{3} \mathrm{O}_{12}$ amorphous precursors in the temperature range of (a) 30 to $900{ }^{\circ} \mathrm{C}$ and (b) 580 to $680{ }^{\circ} \mathrm{C}$. Exothermic peaks are due crystallization of $\mathrm{Y}_{2} \mathrm{~W}_{3} \mathrm{O}_{12}$

Figure 4.5- Room-temperature XRPD patterns and Le Bail fitting of $\mathrm{Y}_{2} \mathrm{~W}_{3} \mathrm{O}_{12}-\mathrm{B} \cdot 2.50 \quad \mathrm{H}_{2} \mathrm{O}$ powder without drying. The experimental pattern is black, the calculated pattern is red and the difference plot is green.

Figure 4.6- Dilatometric curves of bulk specimens consolidated from $\mathrm{Y}_{2} \mathrm{~W}_{3} \mathrm{O}_{12}$-B obtained after oven drying at $170{ }^{\circ} \mathrm{C}$ for (a) 2 days, (b) 5 days, and (c) 10 days and third heating cycle in dilatometer.

Figure 4.7- Particle size distribution in number of the as-prepared $\mathrm{Y}_{2} \mathrm{~W}_{3} \mathrm{O}_{12}$ powders measured by laser diffraction.

Figure 4.8- FEG-SEM images of the calcined $(a-b) \mathrm{Y}_{2} \mathrm{~W}_{3} \mathrm{O}_{12}-\mathrm{A}$ and (c-d) $\mathrm{Y}_{2} \mathrm{~W}_{3} \mathrm{O}_{12}$-B powders.

Figure 5.1- Scheme of the variables defined for the synthesis of $\mathrm{Al}_{2} \mathrm{~W}_{3} \mathrm{O}_{12}$ by co-precipitation.

Figure 5.2- Scheme of the co-precipitation of $\mathrm{Al}_{2} \mathrm{~W}_{3} \mathrm{O}_{12}$ amorphous precursors by mixing reactants, using $\mathrm{Na}_{2} \mathrm{WO}_{4} \cdot 2 \mathrm{H}_{2} \mathrm{O}$ as tungsten source.

Figure 5.3- Scheme of normal strike co-precipitation of $\mathrm{Al}_{2} \mathrm{~W}_{3} \mathrm{O}_{12}$ with $\left(\mathrm{NH}_{4}\right)_{6} \mathrm{~W}_{12} \mathrm{O}_{39} \cdot \mathrm{xH}_{2} \mathrm{O}$ as tungsten source and $\mathrm{AHC}$ as precipitant agent. 
Figure 5.4- Titration curve of the solution formed after mixing aqueous solutions $0.1 \mathrm{M}$ of $\mathrm{Al}\left(\mathrm{NO}_{3}\right)_{3} \cdot 9 \mathrm{H}_{2} \mathrm{O}$ and $\left(\mathrm{NH}_{4}\right)_{6} \mathrm{~W}_{12} \mathrm{O}_{39} \cdot \mathrm{xH}_{2} \mathrm{O}$ up to (a) $\mathrm{pH}=6.0$ and (b) $\mathrm{pH}$ near 8.0. The precipitant was $1.5 \mathrm{M} \mathrm{AHC}$ solution (dripping speed: 2-3 $\mathrm{mLmin}^{-1}$ ).

Figure 5.5- $\mathrm{pH}$ of the aqueous suspension of pAIW-AHC-6 as a function of aging time.

Figure 5.6- XRPD patterns of AIW-4.2-MW sample synthesized by co-precipitation by mixing reactants. The experimental pattern is blue, the calculated pattern is red and the difference plot is black.

Figure 5.7- (a) Zeta potential of $\mathrm{Al}_{2} \mathrm{~W}_{3} \mathrm{O}_{12}$ precursor synthesized via co-precipitation by mixing reactants as a function of $\mathrm{pH}$ during titration with $1 \mathrm{M} \mathrm{NaOH}$ up to $\mathrm{pH} 8$ and (b) schematic representation of precursor particles in reaction medium at $\mathrm{pH}=4.2$ and $\mathrm{pH}=6.0 \ldots \ldots \ldots \ldots \ldots \ldots \ldots \ldots \ldots . . .73$

Figure 5.8- (a) Zeta potential of $\mathrm{Al}_{2} \mathrm{~W}_{3} \mathrm{O}_{12}$ precursor synthesized by normal-strike co-precipitation as a function of $\mathrm{pH}$ during titration with $1.5 \mathrm{M} \mathrm{AHC}$ solution up to $\mathrm{pH} 7.95$ (further increase in $\mathrm{pH}$ was attained through addition of $1 \mathrm{M}$ $\mathrm{NaOH}$ solution) and (b) schematic representation of precursor particles in reaction medium at $\mathrm{pH}=4.2$ and $\mathrm{pH}=6.0$.

Figure 5.9- Particle size distributions in number of $\mathrm{Al}_{2} \mathrm{~W}_{3} \mathrm{O}_{12}$ calcined powders.

Figure 5.10- FEG-SEM images of (a-b) AIW-AHC-4.2-MW and (c-d) AIW-AHC-6.0-MW. .76

Figure 5.11- FEG-SEM images of AIW-6.0-MW sample. 77

Figure 5.12. Scheme of the effects of the studied variables on the agglomeration state of $\mathrm{Al}_{2} \mathrm{~W}_{3} \mathrm{O}_{12}$ submicronic powders .78

Figure 6.1- Dilatometric curves of (a) HDPE and (b) $\mathrm{HDPE} / \mathrm{Y}_{2} \mathrm{~W}_{3} \mathrm{O}_{12^{-}}$ 1.1 composite specimens subjected to three heating cycles. 
Figure 6.2.- Experimental and predicted CTEs of (a) $\mathrm{HDPE} / \mathrm{Al}_{2} \mathrm{~W}_{3} \mathrm{O}_{12}$ and (b) $\mathrm{HDPE} / \mathrm{Y}_{2} \mathrm{~W}_{3} \mathrm{O}_{12}$ composites. Experimental values were measured in the temperature range of $25-70{ }^{\circ} \mathrm{C}$ and during the first heating cycle....................................... 8

Figure 6.3- Young's moduli of (a) $\mathrm{HDPE} / \mathrm{Al}_{2} \mathrm{~W}_{3} \mathrm{O}_{12}$ and (b) $\mathrm{HDPE} / \mathrm{Y}_{2} \mathrm{~W}_{3} \mathrm{O}_{12}$ composites............................................. 91

Figure 6.4- Yield stress of (a) $\mathrm{HDPE} / \mathrm{Al}_{2} \mathrm{~W}_{3} \mathrm{O}_{12}$ and (b)

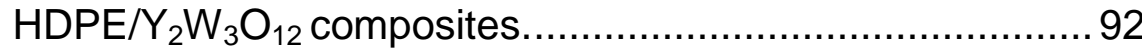

Figure 6.5- Yield strain of (a) $\mathrm{HDPE} / \mathrm{Al}_{2} \mathrm{~W}_{3} \mathrm{O}_{12}$ and (b)

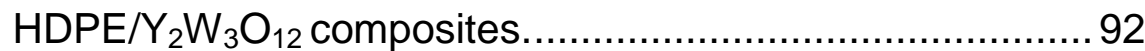




\section{List of Tables}

Table 2.1- Polymer composites filled with particles exhibiting low positive and negative thermal expansion.

Table 2.2- Micromechanical models for prediction of CTE of composites with the corresponding variables and parameters for $\mathrm{HDPE} / \mathrm{Al}_{2} \mathrm{~W}_{3} \mathrm{O}_{12}$ and $\mathrm{HDPE} / \mathrm{Y}_{2} \mathrm{~W}_{3} \mathrm{O}_{12}$ composites.

Table 4.1- CHN results of $\mathrm{Y}_{2} \mathrm{~W}_{3} \mathrm{O}_{12}$ amorphous precursors. ................52

Table 5.1- Nomenclature of $\mathrm{Al}_{2} \mathrm{~W}_{3} \mathrm{O}_{12}$ precursors. .............................66

Table 5.2. $\mathrm{CHN}$ results of $\mathrm{Al}_{2} \mathrm{~W}_{3} \mathrm{O}_{12}$ precursors synthesized by normal strike co-precipitation.

Table 5.3- Crystallization and calcination temperatures of $\mathrm{Al}_{2} \mathrm{~W}_{3} \mathrm{O}_{12}$ as-synthesized precursors.

Table 5.4- $\mathrm{S}_{\mathrm{BET}}, \mathrm{d}_{\mathrm{BET}}$ and $\mathrm{d}_{50}$ parameters of $\mathrm{Al}_{2} \mathrm{~W}_{3} \mathrm{O}_{12}$ powders 76

Table 6.1- Filler loadings used for the preparation of HDPE $/ \mathrm{A}_{2} \mathrm{M}_{3} \mathrm{O}_{12}$ composites and the corresponding composite nomenclature.

Table 6.2- CTEs of HDPE/ $/ \mathrm{Al}_{2} \mathrm{~W}_{3} \mathrm{O}_{12}$ composites for first and second heating cycles in the temperature range of $25-70{ }^{\circ} \mathrm{C}$.

Table 6.3- CTEs of HDPE $/ \mathrm{Y}_{2} \mathrm{~W}_{3} \mathrm{O}_{12}$ composites for first and second heating cycles in the temperature range of $25-70^{\circ} \mathrm{C}$.

Table 6.4- CTEs of HDPE/ $/ \mathrm{Al}_{2} \mathrm{~W}_{3} \mathrm{O}_{12}$ composites for first and second heating cycles in the temperature range of $25-100^{\circ} \mathrm{C}$........84

Table 6.5- CTEs of HDPE $/ \mathrm{Y}_{2} \mathrm{~W}_{3} \mathrm{O}_{12}$ composites for first and second heating cycles in the temperature range of $25-100^{\circ} \mathrm{C}$........84

Table 6.6- Parameters required for application of models for prediction of CTEs of composites. .87

Table 6.7- Thermal properties of $\mathrm{HDPE} / \mathrm{Al}_{2} \mathrm{~W}_{3} \mathrm{O}_{12}$ composites.............90

Table 6.8- Thermal properties of $\mathrm{HDPE} / \mathrm{Y}_{2} \mathrm{~W}_{3} \mathrm{O}_{12}$ composites. 90 


\section{List of abbreviations and symbols}

\begin{tabular}{|c|c|}
\hline$\Delta G^{*}$ & Activation energy for homogeneous nucleation \\
\hline pAIW & $\mathrm{Al}_{2} \mathrm{~W}_{3} \mathrm{O}_{12}$ amorphous precursor \\
\hline APTMS & 3-aminopropyltrimethoxysilane \\
\hline APTES & 3-aminopropyltriethoxysilane \\
\hline $\mathrm{AHC}$ & Ammonium hydrogen carbonate \\
\hline$k$ & Boltzmann's constant \\
\hline BET & Brunauer, Emmett and Teller (BET) method \\
\hline$K_{m}$ & Bulk modulus of matrix \\
\hline$K_{f}$ & Bulk modulus of filler \\
\hline $\mathrm{CHN}$ & Carbon, hydrogen, nitrogen elemental analysis \\
\hline CIPs & Carbonyl iron particles \\
\hline CTE & Coefficient of thermal expansion \\
\hline$\alpha_{c}$ & Coefficient of thermal expansion of composite \\
\hline$\alpha_{m}$ & Coefficient of thermal expansion of matrix \\
\hline$\alpha_{f}$ & Coefficient of thermal expansion of filler \\
\hline$r^{*}$ & Critical radius of embryos \\
\hline$X_{c}$ & Degree of crystallinity \\
\hline$S$ & Degree of supersaturation \\
\hline $\mathrm{d}_{\mathrm{BET}}$ & $\begin{array}{l}\text { Diameter calculated from specific surface area obtained by BET } \\
\text { method }\end{array}$ \\
\hline$d_{50}$ & $\begin{array}{l}\text { Diameter at which } 50 \% \text { of the sample is smaller and } 50 \% \text { is } \\
\text { larger, also called as median diameter. }\end{array}$ \\
\hline DSC & Differential scanning calorimetry \\
\hline DLS & Dynamic light scattering \\
\hline $\mathrm{E}_{\mathrm{i}}$ & Energy level in a potential energy curve \\
\hline$\Delta H$ & Enthalpy change of melting \\
\hline$\Delta H^{*}$ & Enthalpy change of melting for completely crystallized HDPE \\
\hline EDTA & Ethylenediamine tetraacetic acid \\
\hline$b$ & Exponent of equation of growth rate \\
\hline FEG-SEM & Field-emission scanning electron microscopy \\
\hline$K_{g}$ & Growth rate \\
\hline $\mathrm{R}$ & $\begin{array}{l}\text { Hasselman thermal shock resistance figure of merit for severe } \\
\text { heating conditions }\end{array}$ \\
\hline HDPE & High density polyethylene \\
\hline
\end{tabular}




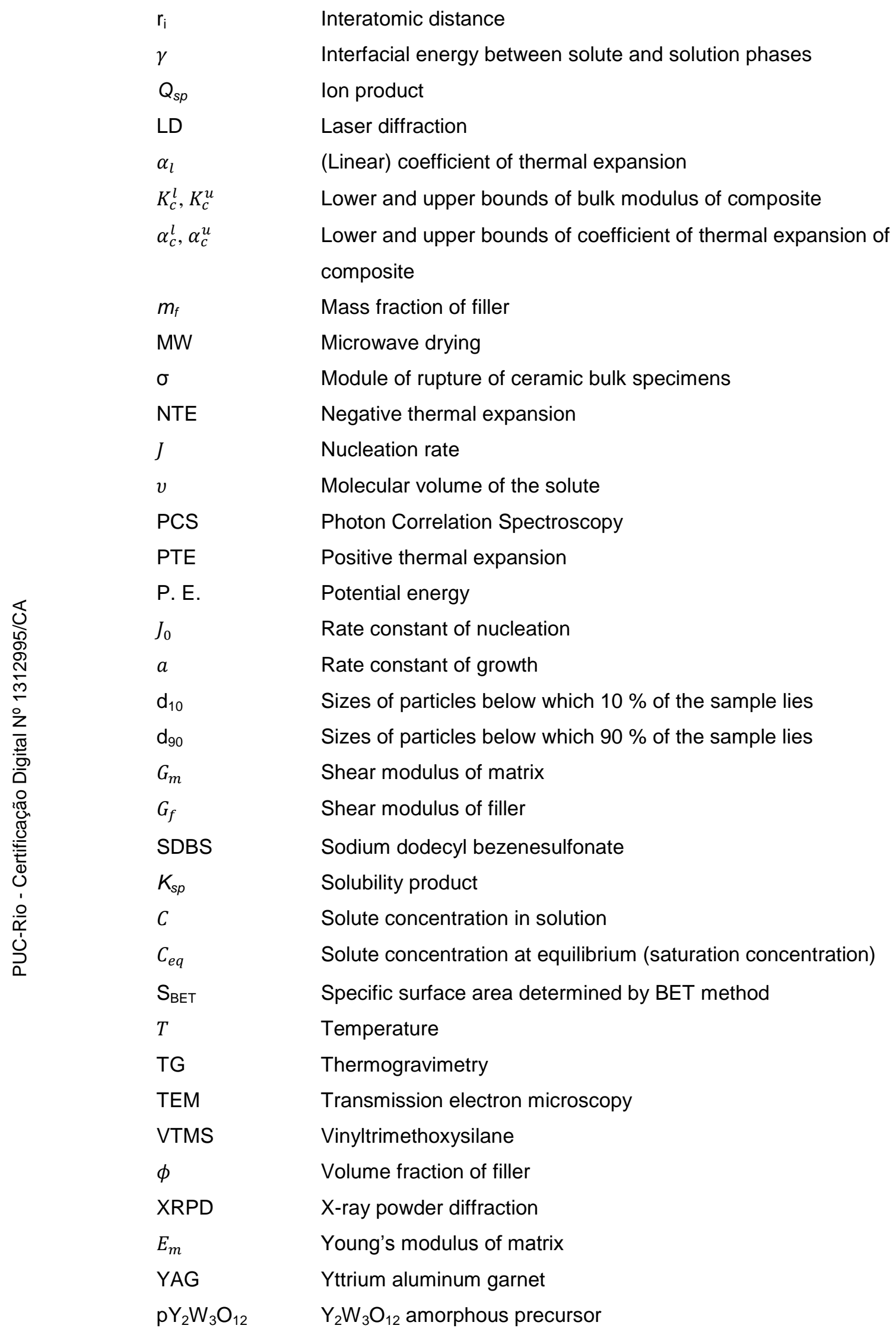


1

\section{Introduction}

One of the major challenges in the field of polymer matrix composites for certain key engineering applications is the fine control of their thermal expansion through the incorporation of dispersed phases, counteracting high CTE of the matrix. Therefore, the addition of inorganic fillers with low-positive, near-zero or negative CTEs might alleviate the shortcomings associated with thermal expansion of polymers at above room service temperatures [1].

In this context, $\mathrm{Al}_{2} \mathrm{~W}_{3} \mathrm{O}_{12}$ and $\mathrm{Y}_{2} \mathrm{~W}_{3} \mathrm{O}_{12}$ are ideal candidates to fulfill the role of fillers for the sake of reducing and controlling thermal expansion of polymer-based composites. $\mathrm{Al}_{2} \mathrm{~W}_{3} \mathrm{O}_{12}$ possesses low thermal expansion $[2,3]$ and remains in the orthorhombic phase in the temperature range from -6 to $1100{ }^{\circ} \mathrm{C}$ $[3,4]$, whilst $\mathrm{Y}_{2} \mathrm{~W}_{3} \mathrm{O}_{12}$ is also orthorhombic and exhibits a negative thermal expansion in the interval of $-258-1100{ }^{\circ} \mathrm{C}[5,6]$. Thus, these materials do not undergo phase transitions in the temperature range of processing polymer matrices $\left(<400{ }^{\circ} \mathrm{C}\right)$.

However, an efficient reduction of thermal expansion of polymer composites without deterioration of mechanical properties can be achieved when deagglomerated fillers are well embedded and dispersed within the matrix. Hence, the development of synthesis routes devoted to prepare nano or submicronic fillers with low agglomeration degree have triggered a lot of research and is one of the motivations of this work.

Thereby, this thesis is intended to study different co-precipitation methods to synthesized $\mathrm{Al}_{2} \mathrm{~W}_{3} \mathrm{O}_{12}$ and $\mathrm{Y}_{2} \mathrm{~W}_{3} \mathrm{O}_{12}$ submicronic powders for application thereof in HDPE-based composites. The thesis is organized as follows:

- Chapter 2: Literature review, which presents the fundamentals of negative thermal expansion in $\mathrm{A}_{2} \mathrm{M}_{3} \mathrm{O}_{12}$ family, the basic principles of coprecipitation and the state of agglomeration of ceramic powders, as well 
as, the trends in polymer-based composites with reduced thermal expansion.

- Chapter 3: Objectives

- Chapter 4: A study of co-precipitation methods for the synthesis of $\mathrm{Y}_{2} \mathrm{~W}_{3} \mathrm{O}_{12}$ submicronic powders.

- Chapter 5: Effects of the synthesis conditions on the agglomeration state of $\mathrm{Al}_{2} \mathrm{~W}_{3} \mathrm{O}_{12}$ submicronic powders prepared by co-precipitation method.

- Chapter 6: Role of $\mathrm{A}_{2} \mathrm{M}_{3} \mathrm{O}_{12}$ submicronic fillers in improving thermal expansion behavior and mechanical properties of HDPE-based composites

- Chapter 7: Conclusions and future works 


\section{2 \\ Literature review}

\section{1.}

\section{Fundamentals of thermal expansion}

Most solid materials expand with increasing temperature, phenomenon that is known as positive thermal expansion (PTE) [7]. From an atomic point of view, PTE is reflected by an increase in the average distance between atoms, which can be better understood taking into account the curve of potential energy (P. E.) as a function of interatomic distance (r), depicted in Figure 2.1 [8]. In this curve, the equilibrium interatomic distance at $0 \mathrm{~K}, \mathrm{r}_{0}$, corresponds to the minimum of the well. Heating to successively higher temperatures $\left(T_{1}, T_{2}, T_{3}\right.$, etc.) increases the vibrational energy from $E_{1}$ to $E_{2}$ to $E_{3}$, and so on. The average vibrational amplitude of an atom is given by the trough width at each temperature, and the average interatomic distance corresponds to the mean position, which increases upon heating from $r_{0}$ to $r_{1}$ to $r_{2}$ and so forth.

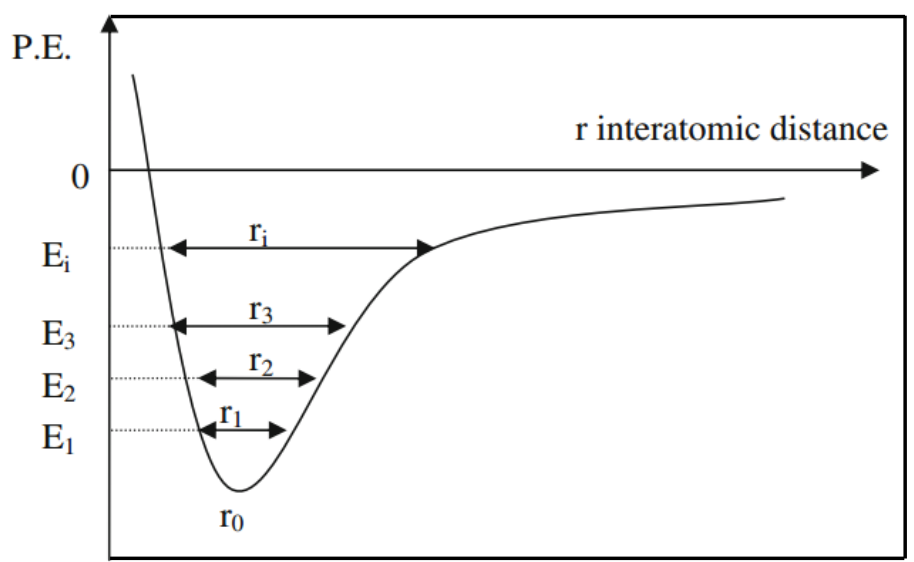

Figure 2.1- Curve of potential energy as a function of the interatomic distance, illustrating the increase in interatomic distance with rising temperature. $E_{i}$ is the energy level and $r_{i}$ is the corresponding interatomic distance [8]. 
As a matter of fact, PTE is due to the asymmetry of the potential energy curve, rather than the increased atomic vibrational amplitudes with rising temperature. If the potential energy curve were symmetric, the interatomic distance would not increase and, therefore, no thermal expansion would exist. Materials with stronger bonds exhibit deeper and narrower potential wells, resulting in a slower rate of increase in interatomic distance and, consequently, a smaller CTE [8].

Bearing in mind the origin of PTE, a low thermal expansion can be expected for several materials, but negative thermal expansion (NTE) cannot be explained based on the behavior of interatomic bonds illustrated by the curve of potential energy. Indeed, this curve considers merely the component of relative longitudinal vibrational motion, which is directed along the line joining the atoms. The NTE generally arises from other mechanisms that can overcome the PTE of interatomic bonds, such as vibrational effects (NTE due to transverse vibrations) or non-vibrational mechanisms, which emerge from ferroelectric or magnetic effects, or phase transitions [9]. It is worthwhile to mention that the term "thermomiotic" introduced by Romao et al. [7], from the Greek "thermo" for heat and "mio" for contraction, is widely used to refer to NTE materials.

\section{2. \\ NTE arising from transverse vibrations}

Phonons are quantized lattice vibrations in a crystal. There are two important phone modes: longitudinal and transverse vibrations [7,8]. A schematic representation of these vibrational modes for the metal-oxygen-metal $(\mathrm{M}-\mathrm{O}-\mathrm{M})$ linkage is shown in Figure 2.2.

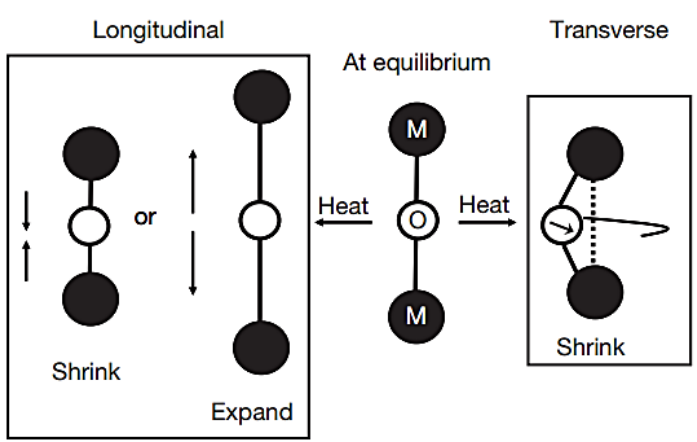

Figure 2.2- Longitudinal and transverse vibrations for the M-O-M linkage [7]. 
The longitudinal vibrations comprise alternating compression and expansion of the $\mathrm{M}-\mathrm{O}-\mathrm{M}$ linkage and because of the asymmetry of the potential energy well, the average effect is PTE. Hence, longitudinal vibration modes tend to increase the $\mathrm{M}-\mathrm{O}$ bond length and, consequently, $\mathrm{M}----\mathrm{M}$ interatomic distance with rising temperature (see Figure 2.2). However, the effective M----M distance can decrease due to transverse vibrations of oxygen in the $\mathrm{M}-\mathrm{O}-\mathrm{M}$ linkage. In this case, the change in $\mathrm{M}-\mathrm{O}-\mathrm{M}$ angle is caused by the increase in amplitude of the oxygen atom's vibration [8].

The response of $\mathrm{M}$----M length depends on the dominating vibrational mode. There are many open-framework structures of metal oxides, where these transverse modes give rise to NTE [8]. These structures are composed by networks of polyhedral structural units (tetrahedra or octahedra) linked at their corners by shared oxygen atoms, which take part in the $\mathrm{M}-\mathrm{O}-\mathrm{M}$ linkage, as shown in Figure 2.3.

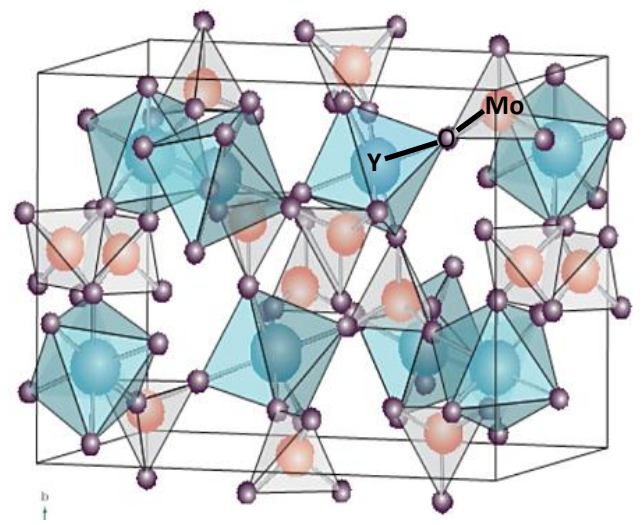

Figure 2.3- $\mathrm{Y}_{2} \mathrm{Mo}_{3} \mathrm{O}_{12}$ open-framework structure at room temperature, corner-sharing $\mathrm{YO}_{6}$ octahedra and $\mathrm{MO}_{4}$ thetrahedra [10].

Owing to the corner-sharing nature of open-frameworks, the polyhedra can be subjected to intensive tilting or rocking motions when transverse vibrations of the corner-sharing oxygen atoms are excited [11], see Figure 2.4. The polyhedra must rotate in a cooperative manner without much destruction of their polyhedral units [7]. This process results in a reduction of $\mathrm{M}----\mathrm{M}$ distances in $\mathrm{M}-\mathrm{O}-\mathrm{M}$ linkage, giving rise to NTE, considering that the $\mathrm{M}-\mathrm{O}$ bonds are strong enough and almost unchanged. The transverse motions of $\mathrm{M}-\mathrm{O}-\mathrm{M}$ linkage are 
coordinated by the overall network, considering polyhedral as rigid or semi-rigid units [7].

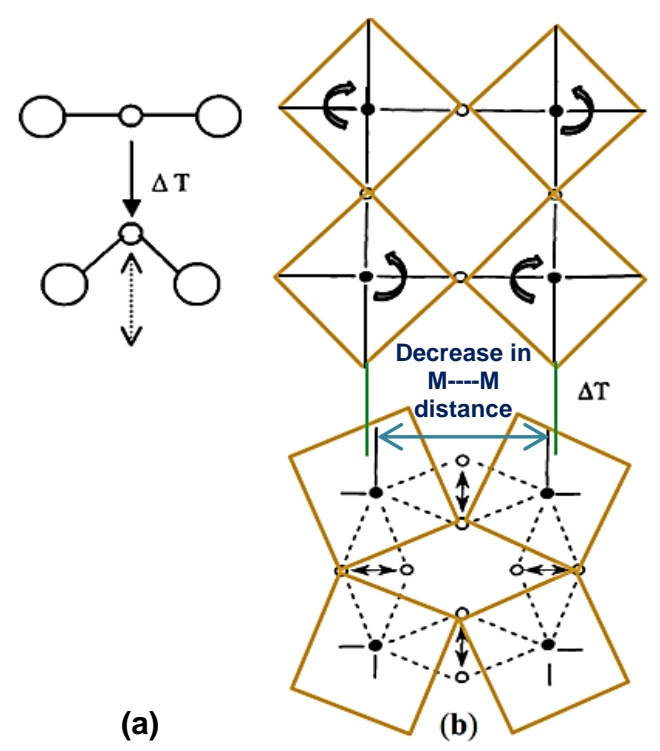

Figure 2.4- Schemes of vibrational modes giving rise to NTE: (a) transverse vibrations of an oxygen atom in the M-O-M linkage and (b) cooperative rocking motion of polyhedra responsible for the shrinkage of $\mathrm{M}----\mathrm{M}$ distance [11].

There are five requirements that must be satisfied for a compound to show low thermal expansion or NTE [12]:

- The existence of strong $\mathrm{M}-\mathrm{O}$ bonds exhibiting inherently low expansion.

- 2 coordinate oxygen to enable transverse vibrations.

- Open-framework structure that can endure low-energy transverse vibrational modes.

- Interstitials sites in framework are empty.

- Absence of phase transitions to lower symmetry or lower volume structures.

\section{3.}

\section{Families of thermomiotics applied in polymer-based composites}

There are six families of metal oxides that display NTE: $\mathrm{AO}_{3}, \mathrm{AM}_{2} \mathrm{O}_{7}$, $\mathrm{AMO}_{5}, \mathrm{M}_{2} \mathrm{O}, \mathrm{AM}_{2} \mathrm{O}_{8}$ and $\mathrm{A}_{2} \mathrm{M}_{3} \mathrm{O}_{12}$. Among them, $\mathrm{AM}_{2} \mathrm{O}_{8}$ and $\mathrm{A}_{2} \mathrm{M}_{3} \mathrm{O}_{12}$ families have been used as dispersed phases in polymer-based composites, specially the first one [7]. 
In $\mathrm{AM}_{2} \mathrm{O}_{8}$ family, $\mathrm{A}$ is a cation capable of assuming octahedral coordination and $\mathrm{M}$ is $\mathrm{W}^{6+}$ or $\mathrm{Mo}^{6+}$. The representative member of this family is $\mathrm{ZrW}_{2} \mathrm{O}_{8}$ and its structure comprises $\mathrm{ZrO}_{6}$ octahedra, which are connected through $\mathrm{WO}_{4}$ tetrahedra via corner-sharing. Each $\mathrm{ZrO}_{6}$ is connected to six $\mathrm{WO}_{4}$ units, while each $\mathrm{WO}_{4}$ tetrahedron is merely bound to three $\mathrm{ZrO}_{6}$ octahedra, leaving one oxygen atom per $\mathrm{WO}_{4}$, as shown in Figure 2.5. Because of this connectivity, $\mathrm{ZrW}_{2} \mathrm{O}_{8}$ presents a highly flexible network [13]. The unit cell of $\mathrm{ZrW}_{2} \mathrm{O}_{8}$ is cubic, consequently, this material exhibits isotropic NTE, with a linear coefficient of thermal expansion $\left(\alpha_{l}\right)$ of $-9 \times 10^{-6}{ }^{\circ} \mathrm{C}^{-1}$ in the temperature range of $-273-777{ }^{\circ} \mathrm{C}$ [13]. This temperature interval includes the processing and service temperatures of polymer matrices.

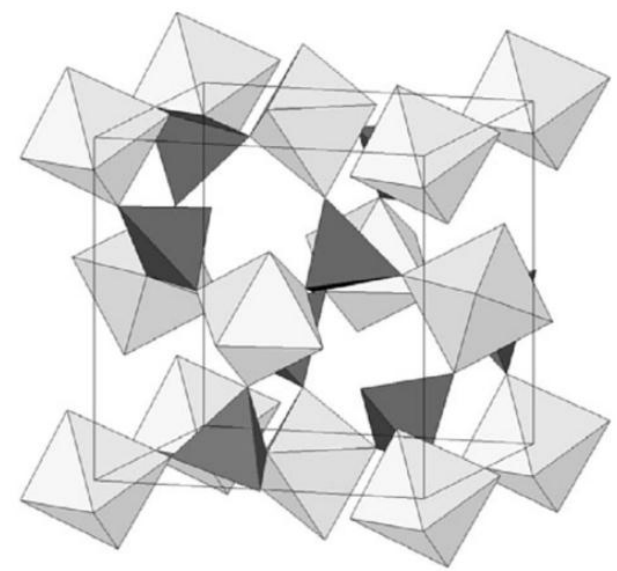

Figure 2.5- Crystal structure of $\mathrm{ZrW}_{2} \mathrm{O}_{8}$, where $\mathrm{ZrO}_{6}$ octahedra are pale grey and $\mathrm{WO}_{4}$ tetrahedral are grey [13].

In $\mathrm{A}_{2} \mathrm{M}_{3} \mathrm{O}_{12}$ family, $\mathrm{A}$ is a trivalent transition metal or a lanthanide from $\mathrm{Lu}$ to Ho, while $\mathrm{M}$ is a hexavalent cation, such as $\mathrm{W}^{+6}$ or $\mathrm{Mo}^{+6}$. These open frameworks built from $\mathrm{AO}_{6}$ octahedra and $\mathrm{MO}_{4}$ tetrahedra are linked through corner connectivity, as depicted in Figure 2.3. This family commonly presents a phase transition from the lower-temperature monoclinic to the higher-temperature orthorhombic crystal system [14]. Transverse thermal vibrations of oxygen anions perpendicular to A-O-M linkages give rise to NTE displayed in the orthorhombic crystal system. The strongest NTE in this family is caused by the presence of large A cations, such as $\mathrm{Y}^{3+}$. Large radii cations cause weakening of attractive forces 
between $\mathrm{A}^{3+}$ and $\mathrm{O}^{2-}$, thus providing higher distortability of $\mathrm{AO}_{6}$ polyhedra, which is the requisite for NTE in this ceramic family [15].

Among $\mathrm{A}_{2} \mathrm{M}_{3} \mathrm{O}_{12}$ family members, only $\mathrm{Al}_{2} \mathrm{Mo}_{3} \mathrm{O}_{12}$ and $\mathrm{Y}_{2} \mathrm{Mo}_{3} \mathrm{O}_{12}$ have been reported in the literature as fillers of polymer-based composites $[1,16]$. However, there is a variety of members belonging to this family with potential for application in this field. Actually, an advantage of $\mathrm{A}_{2} \mathrm{M}_{3} \mathrm{O}_{12}$ compounds is their wide chemical flexibility, which results in a diversity of orthorhombic phases with CTEs ranging from $-12 \times 10^{-6}$ to $2 \times 10^{-6}{ }^{\circ} \mathrm{C}^{-1}$ [10]. Even when these compounds are in the monoclinic phase, as is the case of $\mathrm{Al}_{2} \mathrm{Mo}_{3} \mathrm{O}_{12}$ at room temperature, the magnitude of their CTEs is still low [17]. Contraty to $\mathrm{ZrW}_{2} \mathrm{O}_{8}$ and related compounds, several $\mathrm{A}_{2} \mathrm{M}_{3} \mathrm{O}_{12}$ materials can be synthesized from inexpensive reactants [1].

\section{4.}

\section{Synthesis of thermomiotics by co-precipitation}

Thermomiotics are usually synthesized via two chemical approaches: i) solid-state synthesis at high temperatures and ii) soft (wet)-chemistry routes, such as sol-gel, hydrothermal method, co-precipitation and recently, combustion synthesis and total evaporation route $[7,18,19]$.

Among these methods, co-precipitation is one of the most promising techniques because of the inexpensive reactants, a simple synthesis process and commonly available apparatus. Moreover, this method is especially suitable for preparation of nano or submicronic powders and has the advantage of producing precursors in which elements are mixed at an atomic level [20].

In co-precipitation, high levels of supersaturation are created and homogeneous nucleation of insoluble amorphous precipitates predominates. The nuclei tend to growth and then, the precipitated precursor is recovery from the solution. After washing and drying, the amorphous precursor is calcined at the crystallization temperature required to obtain the desired thermomiotic phase [7].

In spite of the advantages of co-precipitation, only few phases of $\mathrm{A}_{2} \mathrm{M}_{3} \mathrm{O}_{13}$ family have been synthesized by this method, such as: $\mathrm{Al}_{2} \mathrm{~W}_{3} \mathrm{O}_{12}$ [21], $\mathrm{Al}_{2} \mathrm{Mo}_{3} \mathrm{O}_{12}$ [17] and $\mathrm{Al}_{2-\mathrm{x}-\mathrm{y}} \mathrm{In}_{\mathrm{x}} \mathrm{Cr}_{\mathrm{y}} \mathrm{W}_{3} \mathrm{O}_{12}$ [22]. The solid state synthesis is still the most popular route. 


\subsection{1. \\ Basic principles of co-precipitation}

The co-precipitation process from supersaturated liquid solutions involves three major stages: embryo formation, homogeneous nucleation of stable nuclei and their growth. Embryos are formed as a result of the interaction between ions and molecules in the solution and are capable of growth and re-dissolution until a critical size $\left(r^{*}\right)$ is reached. Thus, only embryo (nucleus) equal to or larger than a critical radius may grow as a stable nucleus. This critical nucleus is capable to overcome the activation energy and to result in nucleation and afterwards, growth. The energy barrier $\left(\Delta G^{*}=\right.$ activation energy) depends on the level of supersaturation $(S)$ and decreases with the increase of supersaturation as given by Equation (2.1), while critical nucleus radius follows the same trend [23].

$\Delta G^{*}=\frac{16 \pi v^{2} \gamma^{3}}{3(k T)^{2}(\operatorname{lnS})^{2}}$

where, $v$ represents the molecular volume of the solute, $\gamma$ is the interfacial energy between solute and solution phases, $k$ is the Boltzmann's constant and $T$ is the temperature in Kelvin. The degree of supersaturation $(S)$ is defined by the ratio between the solute concentration in solution $(C)$ and saturation concentration $\left(C_{e q}\right)$, which is the solute concentration at equilibrium, using Equation (2.2) [23]:

$S=\frac{C}{C_{e q}}$

Therefore, supersaturation is the driving force for co-precipitation. Typically, the supersaturation level of the precipitating phase in aqueous solution can be achieved through control of $\mathrm{pH}$ by chemical reactions with or without the aid of a precipitant agent.

The nucleation rate $(J)$ for homogeneous nucleation can be computed by Equation (2.3), while the growth rate $\left(K_{g}\right)$ can be estimated by Equation (2.4) [23,24]: 
$J=J_{0} \exp \left[-\frac{16 \pi v^{2} \gamma^{3}}{3(k T)^{3}(\ln S)^{2}}\right]$

$K_{g}=a\left(c-c_{e q}\right)^{b}$

where $J_{0}$ and $a$ are the rate constants of nucleation and growth, respectively. $C_{e q}$ is approximately zero for most hydroxides and carbonates. The exponent $b$ is usually only $1-2$ and often is close to 1 [24], thus:

$K_{g} \sim a S$

Therefore, high supersaturation levels boost nucleation rather than crystal growth and also the formation of fine precipitates composed by a great number of smaller particles.

Based on the fundamentals of thermodynamics, a solution is supersaturated when the ion product $\left(Q_{s p}\right)$ of the precipitate is higher than its solubility product $\left(K_{s p}\right)$, whereas a saturated solution is formed when $Q_{s p}$ is equal to $K_{s p}$. Actually, $K_{s p}$ is the equilibrium constant of the precipitate in a saturated solution and can be used to compute the $\mathrm{pH}$ to reach the saturation level. Above this $\mathrm{pH}$ value the supersaturation is attained and co-precipitation takes place.

These concepts can be better understood considering, for instance, the precipitation of $\mathrm{Y}(\mathrm{OH})_{3}$, given by the following chemical reaction [20]:

$Y^{3+}(a q)+3 O H^{-}(a q) \rightarrow Y(O H)_{3}(s)$

The value of $K_{s p}$ can be calculated as follows:

$K_{s p}=\left[Y^{3+}\right]_{e q}\left[O H^{-}\right]_{e q}^{3}$

where, $\left[\mathrm{Y}^{3+}\right]_{e q}$ and $\left[\mathrm{OH}^{-}\right]_{e q}$ are the concentrations of $\mathrm{Y}^{3+}$ and $\mathrm{OH}^{-}$at equilibrium. The supersaturation can be also expressed in terms of $K_{s p}$ and $\mathrm{Q}_{\mathrm{sp}}$ by Equation (2.7): 
$S=\frac{Q_{s p}}{K_{s p}}$

The value of $Q_{s p}$ can be computed with Equation (2.8), as follows:

$Q_{s p}=\left[Y^{3+}\right]\left[O H^{-}\right]^{3}$

where, $\left[\mathrm{Y}^{3+}\right]$ and $\left[\mathrm{OH}^{-}\right]$are the actual concentration of $\mathrm{Y}^{3+}$ and $\mathrm{OH}^{-}$.

Thus, the supersaturation can be expressed as a function of $\mathrm{pH}$, since it depends on $\left[\mathrm{OH}^{-}\right]$:

$S=\frac{\left[\mathrm{Y}^{3+}\right]\left[\mathrm{OH}^{-}\right]^{3}}{K_{S p}}$

The last equation demonstrates that high $\mathrm{pH}$ conditions give rise to supersaturation levels much higher than those obtained at low $\mathrm{pH}$ conditions, thus, promoting high nucleation rates. The same trend can be applied to concentrated solutions, which create supersaturation degrees greater than those attained from dilute solutions.

\subsection{2.}

\section{Types of co-precipitation method}

There are three co-precipitation methods widely studied: i) normal strike co-precipitation, ii) reverse strike co-precipitation and ii) co-precipitation by simultaneous mixing of reactants [24]. These methods are depicted in Figure 2.6.

In a normal strike co-precipitation a precipitant solution (basic solution) is dropped into an acidic solution of reactant salts [24]. This synthesis is carried out at low $\mathrm{pH}$ condition, since the initial $\mathrm{pH}$ of the reaction medium is that of the solution of reactant salts [25]. The reactant salts are usually aqueous solutions of nitrates, chlorides or sulfides of the corresponding metals that will be precipitated, while the precipitant agents can be aqueous solutions of sodium hydroxide $(\mathrm{NaOH})$, ammonium hydroxide $\left(\mathrm{NH}_{4} \mathrm{OH}\right)$ or ammonium hydrogen carbonate $\left(\mathrm{AHC}=\mathrm{NH}_{4} \mathrm{HCO}_{3}\right)$. Hence, amorphous hydroxide-based precursors or carbonate- 
based precipitates can be obtained. Sequential precipitation of metal hydroxides or carbonates can occur depending on their corresponding $K_{s p}$ values [24]. In the case of $\mathrm{A}_{2} \mathrm{M}_{3} \mathrm{O}_{12}$ family members, it is described in the literature the synthesis of $\mathrm{Al}_{2} \mathrm{Mo}_{3} \mathrm{O}_{12}$ [17] by normal strike method, adding $1 \mathrm{M}$ aqueous solution of $\mathrm{NaOH}$ into the aqueous solution formed after mixing $0.1 \mathrm{M}$ solutions of $\mathrm{Al}\left(\mathrm{NO}_{3}\right)_{3} \cdot 9 \mathrm{H}_{2} \mathrm{O}$ and $\left(\mathrm{NH}_{4}\right)_{6} \mathrm{Mo}_{7} \mathrm{O}_{24} \cdot 4 \mathrm{H}_{2} \mathrm{O}$.
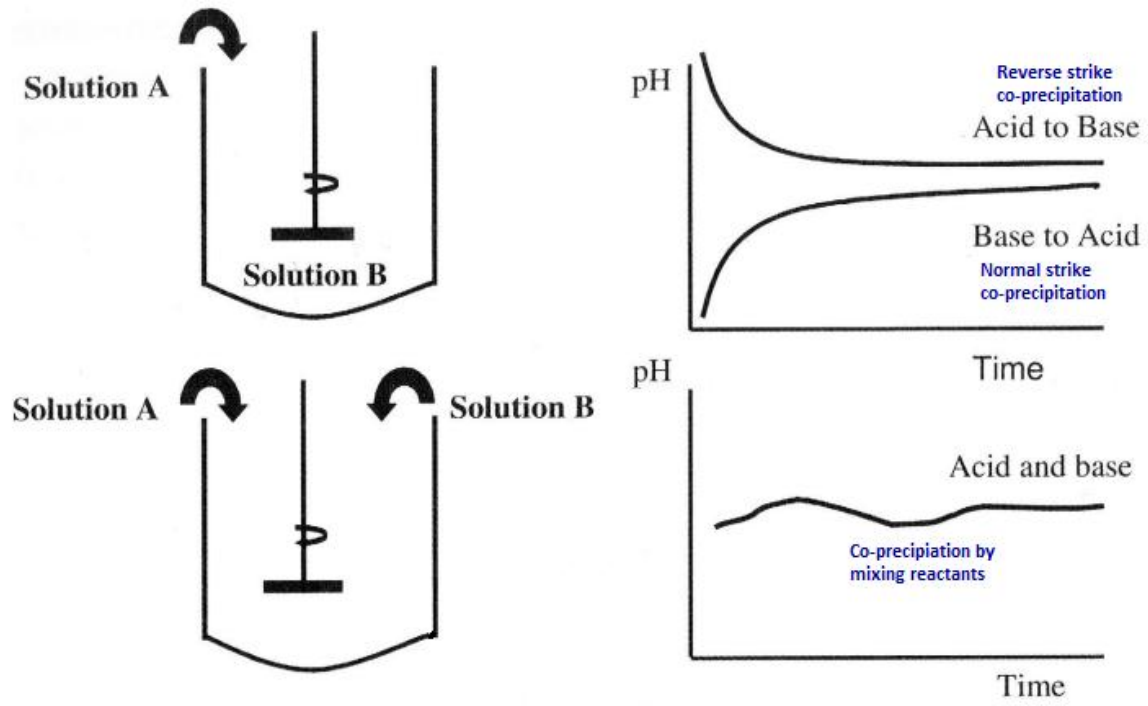

Figure 2.6- Differences between types of co-precipitation methods [24].

On the other hand, in reverse strike co-precipitation the acidic solution of reactant salts is added into a basic solution of the precipitant agent [24]. For reverse strike method or high $\mathrm{pH}$ condition, the supersaturation levels are much higher than those of normal strike co-precipitation, which would promote nucleation, rather than growth, and the formation of precipitates comprising small particles. In addition, high $\mathrm{pH}$ condition of reverse strike assures that the $K_{s p}$ value of the precipitate is always, and highly, exceeded [24,25] and sequential precipitation of metals is not a problem. Reverse strike co-precipitation can be conducted in two different ways: i) at constant $\mathrm{pH}$ (using a large amount of precipitant agent solution and/or adding an extra volume of this precipitant solution as co-precipitation proceeds in order to keep the $\mathrm{pH}$ constant) [26] and ii) at variable $\mathrm{pH}$ ( $\mathrm{pH}$ of the precipitant solution drops as a function of time) [25], as shown in Figure 2.6. 
The third co-precipitation method is carried by using a simultaneous addition of reactants and usually without the aid of a precipitant agent, as reported by Zhecheva et al. [21] for the synthesis of $\mathrm{Al}_{2} \mathrm{~W}_{3} \mathrm{O}_{12}$ through direct mixture of $0.1 \mathrm{M}$ aqueous solution of $\mathrm{Al}\left(\mathrm{NO}_{3}\right)_{3} \cdot 9 \mathrm{H}_{2} \mathrm{O}$ and $\mathrm{Na}_{2} \mathrm{WO}_{4} \cdot 2 \mathrm{H}_{2} \mathrm{O}$.

\section{5 .}

\section{State of agglomeration of ceramic powders}

Ceramic powders are constituted of individual primary particles or their agglomerates. Primary particles, in turn, are composed from one or various crystallites. Since they are the simplest entity of a powder, they cannot be further broken during processing. On the other hand, an agglomerate, named as secondary particle, is defined as an assembly of primary particles forming a network of interconnective pores [27,28]. The difference between primary particles and agglomerates is depicted in Figure 2.7. Depending on the strength of the interaction between primary particles, agglomerates may or may not be broken apart during subsequent processing.

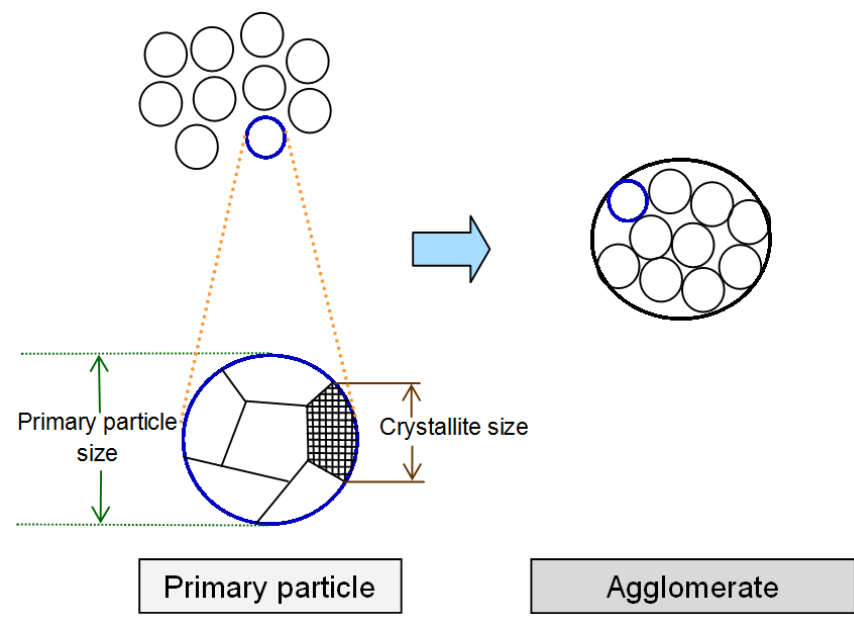

Figure 2.7- Scheme of different levels of agglomeration of ceramic powders, adapted from [29].

Agglomerates of ceramic powders can be classified into two types: i) soft agglomerates, in which nanoparticles are held together by weak van der Waals interactions, and ii) hard agglomerates (often referred as aggregates), where nanoparticles are chemically or physically bonded through strong bridges. 
Therefore, soft agglomerates can be broken easily into primary particles or at least into much smaller agglomerates under slight mechanical forces or ultrasonication. However, hard agglomerates cannot be disintegrated into primary particles and need strong mechanical forces for breaking down into smaller agglomerates [27].

The most important physical properties of ceramic powders are the size of primary particles and their morphology, particle size distribution of agglomerates, as well as, the state of agglomeration [28].

The specific surface area of powders, determined using Brunauer, Emmett and Teller (BET) method, allows calculation of the mean primary particle size $\left(\mathrm{d}_{\mathrm{BET}}\right)$, usually assuming particles with spherical shape [28]. This size can be verified by transmission electron microscopy (TEM) and the morphology of primary particles can be also studied by this technique. The comparison between mean primary particle size and the average size of agglomerates can be considered as a measure of the state of agglomeration of ceramic powders [30]. It is important to point out that crystallite size, measured by the X-ray diffraction line broadening, does not allow making conclusions on the state of agglomeration of powders.

The characterization of powder agglomerate properties is much less standardized. Particle size distributions of agglomerates are commonly measured by laser diffraction (LD) and dynamic light scattering (DLS) [28].

In a typical LD experiment, a collimated laser beam illuminates particles, which cause the light to be scattered in different directions. The particle size distribution is obtained through the measurement of the scattered intensity as a function of the scattered angle. Large particles cause a high scattered intensity at low angles relative to the laser beam, whilst small particles create a low intensity signal at large angles, as depicted in Figure 2.8 [31]. These angular scattering patterns are measured with a proper detector. He-Ne lasers with a wavelength of $633 \mathrm{~nm}$ are normally used as the light source [32]. LD analysis equipments are able to characterize particles ranging from hundreds of nanometers up to several millimeters in size $(0.05-3500 \mu \mathrm{m})$ [33]. This technique provides a volume-based distribution, assuming a volume equivalent sphere model. However, results can be also displayed on surface area or number basis. The conversion from one distribution to another is supplied in the software and it is merely provided for 
comparison to other techniques, such as microscopy, which inherently measures a number distribution of particles [34].

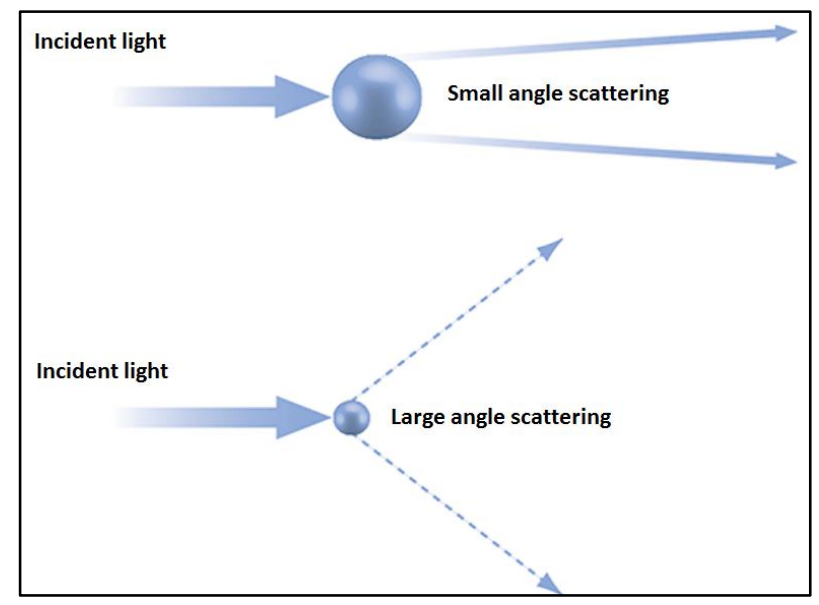

Figure 2.8- Scattering of light from large and small particles [31].

One of the most important parameters that defines a particle size distribution measured by $\mathrm{LD}$ is $\mathrm{d}_{\mathrm{V} 50}$. It represents the size in microns at which $50 \%$ of the sample is smaller and $50 \%$ is larger. This value is also known as the median diameter. The subscript " $V$ " refers to a volume distribution, but it can be replaced by " $S$ " for surface or " $N$ " for number distributions. Other parameters reported from LD results are $d_{10}$ and $d_{90}$ that correspond to the sizes of particles below which $10 \%$ and $90 \%$ of the sample lies, respectively. LD ananlyses can be carried out in wet or dry powder sample dispersion units. In the first case, a liquid (water or another solvent) is used as a dispersant, whereas in dry units a gas stream, usually dry air is the dispersant medium [31].

DLS technique, also called "Photon Correlation Spectroscopy" (PCS), is used to measure the particle size distribution in the range of $2 \mathrm{~nm}$ to $500 \mathrm{~nm}$ [33]. DLS measures the light scattered from a laser passing through a suspension of particles and determines the hydrodynamic size of particles and particle agglomerates analyzing the scattered light intensity as a function of time [35]. Large particles will diffuse slower than small ones. The hydrodynamic diameter is equivalent to that of a sphere that would move with the same translational diffusion coefficient and is the as-called "Z-average value" (see Figure 2.9). This parameter is typically the mean value from the intensity distribution. It is possible 
to convert intensity distribution to volume or number distributions to make comparisons with other techniques [34].

\section{Dry powder}

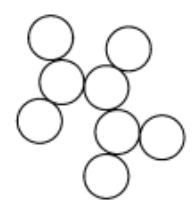

\section{Liquid suspension}

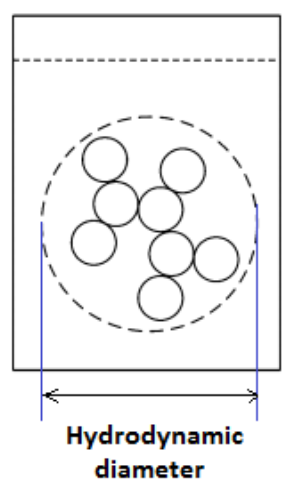

Figure 2.9- Schematic representation of the hydrodynamic diameter of particles (Zaverage value from intensity distribution) measured by DLS, adapted from [36].

\subsection{1.}

\section{Factors influencing the agglomeration state of ceramic powders}

The preparation of thermomiotic powders via co-precipitation involves four main stages: i) synthesis of an amorphous precursor, ii) washing step, iii) drying of the as-prepared precursor and iv) calcination of the precursor to obtain the desired crystalline thermomiotic phase, as briefly mentioned in section 2.4 . The conditions of all these stages can contribute to the final agglomeration state of the thermomiotic powder.

During synthesis of the amorphous precursors the $\mathrm{pH}$, temperature, type of reactant salts and initial concentration, co-precipitation method, type of precipitant agent, its concentration and dripping speed, as well as, aging time are paramount factors to control the agglomeration degree of precursors [37,38]. Depending on the co-precipitation method and precipitant agent, hydroxide or carbonate-based precursors can be formed. Hydroxide precursors are usually highly agglomerated due to the bridging of adjacent precursor particles (rich in $\mathrm{OH}^{-}$groups) with water molecules by hydrogen bond and the huge capillary forces induced during drying [39]. Conversely, when a carbonate precursor is produced, the possibility of 
hydrogen bond formation between adjacent precursor particles could be significantly reduced during drying and, therefore, particle agglomeration.

Another important factor that strongly influences on agglomeration of powders is the washing process. Water molecules, hydrogen-bonded to surface hydroxyl groups, are capable to form bridges between adjacent particles during drying, responsible for agglomeration. On the other hand, ethanol washing can reduce agglomeration, because the ethoxy groups can hydrogen bond to surface $\mathrm{OH}^{-}$groups and reduce the particle-particle interaction [40], as depicted in Figure 2.10. Furthermore, ethoxy groups produce sterically hindered effects to prevent agglomeration of precursor nanoparticles. Ethanol possesses a low surface tension $\left(23 \mathrm{mNm}^{-1}\right.$ at $\left.20{ }^{\circ} \mathrm{C}\right)$ and boiling point $\left(78{ }^{\circ} \mathrm{C}\right)$. Thus, it easily evaporates during drying compared to water (surface tension $=73 \mathrm{mNm}^{-1}$ at $20{ }^{\circ} \mathrm{C}$ ). The lower surface tension of ethanol can also avoid the capillary force during drying, reducing particle agglomeration.

(a)

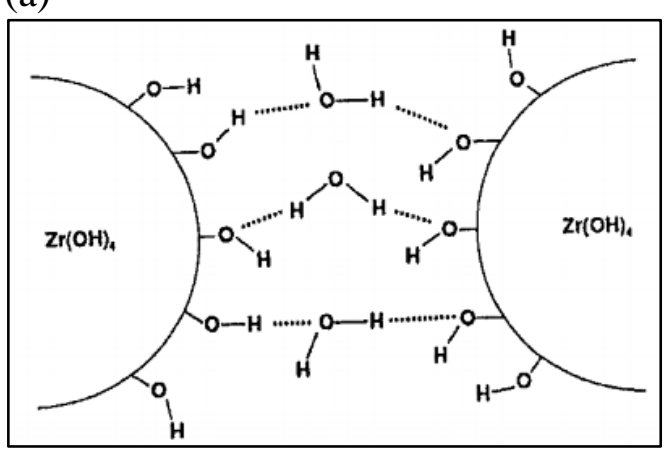

(b)

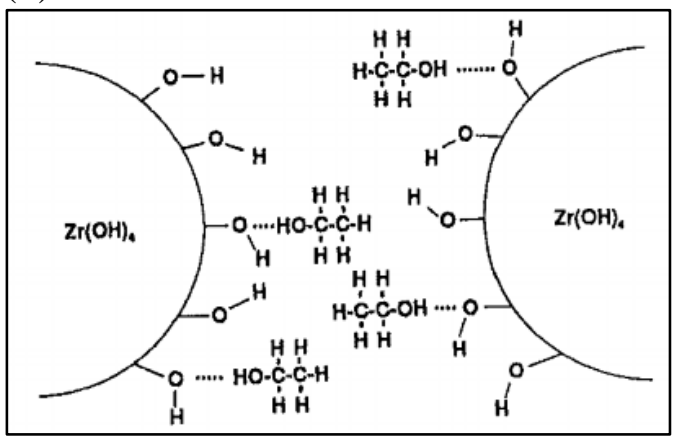

Figure 2.10- (a) Water washed $\mathrm{Zr}(\mathrm{OH})_{4}$ gels and (b) ethanol-washed zirconia gels [40].

During a typical drying process, agglomerates between adjacent particles may be formed when the capillary forces overcome the interparticle repulsive forces and push particles together (see Figure 2.11.a) [41]. These capillary forces can be due to either liquid or gas bridges formed as solvent evaporation proceeds, as depicted in Figure 2.11.b. Therefore, drying techniques intended to reduce the capillary forces can prevent particle agglomeration [42]. 
(a)

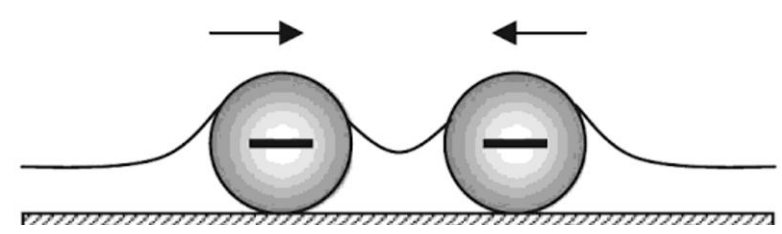

(b)

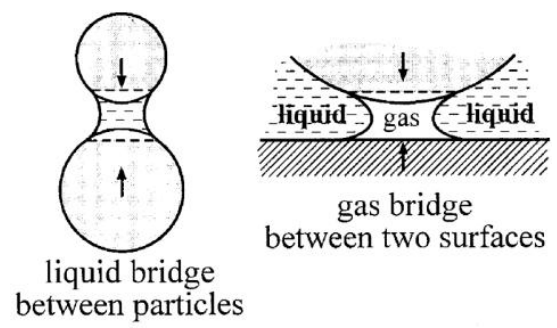

Figure 2.11- (a) Illustration of capillary forces bringing particles close to each other and (b) liquid or gas bridges giving rise to capillary walls [43].

Capillary forces are proportionally to capillary presure $(P)$, which can be expressed by Equation (2.10) [42]:

$P=\frac{2 \sigma \cos \theta}{r_{p}}$

where, $\sigma$ is the liquid/vapor interfacial energy (or surface tension), $\theta$ is the contact angle, and $r_{p}$ is the radius of curvature. Thus, capillarity pressure can be reduced by the following means [42]:

- Reducing surface tension (using freeze-drying and solvent-replacement drying).

- Modifying the wetting angle to approach it to $90^{\circ}$ (surface-modification drying).

- Using ethanol-dehydration technique followed by microwave drying because the surface tension of ethanol is low, while microwave drying allows reducing the drying period and heats precursors evenly [44].

Besides, in the initial stage of conventional oven drying the particles are bound together only by weak van der Waals forces. Nevertheless, for metal oxides the bonds between particles are gradually strengthened via condensation reactions between surface $\mathrm{OH}^{-}$groups and by dissolution-reprecipitation to form necks between particles. This process leads to the development of solid bridges, which can be retained during calcination process [41].

Finally, during calcination of precursors, the temperature, time, rate of heating and atmosphere can also have a great influence on the agglomeration state of thermomiotic powders. 


\subsection{2.}

\section{Drying techniques of precursors}

One of the most promissory techniques for decreasing particle agglomeration of precursors is freeze-drying. In this technique an aqueous suspension of particles is frozen and subsequently, ice is allowed to sublime under vacuum. Water undergoes some volume expansion when freezing, which can separate adjacent particles when water transforms into ice (see Figure 2.12) [42,45]. Moreover, high-energy liquid/vapor interfaces are replaced by low energy solid/vapor interfaces. Thus, agglomeration of adjacent particles induced by capillary forces can be mitigated in theory. However, capillary problems could appear when residual water remains in particle pores as a result of incomplete freezing or when temperature increases too early at the end of the drying process [45].

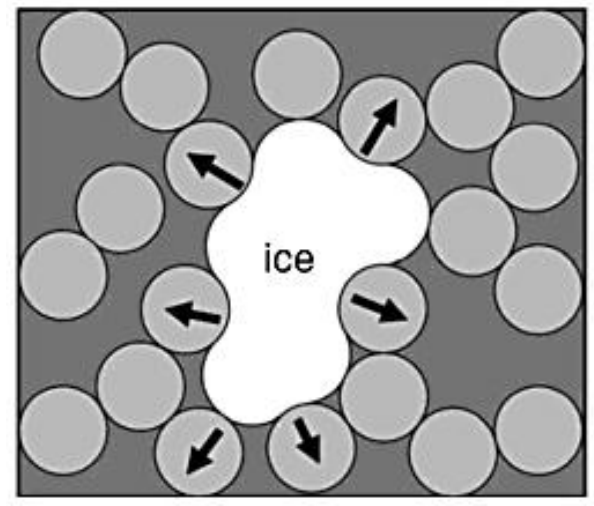

Figure 2.12- Growth of ice inside the precursor gel, pushing primary particles apart [45].

The freeze-drying is usually carried out at $-10{ }^{\circ} \mathrm{C}$ and absolute pressures of $2 \mathrm{mmHg}$ (0.013 bar) [46]. Actually, for commonly studied yttrium aluminum garnet (YAG) precursors, freeze-drying has been conducted at $-80{ }^{\circ} \mathrm{C}$ and pressures as low as 0.007 bar for $24 \mathrm{~h}$ [47]. It is important to point out that there is a misunderstanding in literature about the freeze-drying process of precipitates after washing them with ethanol, where this process has been performed at temperatures higher than that required for freezing ethanol $\left(-114^{\circ} \mathrm{C}\right)[38,48]$. In this case, the proper term is "vacuum drying" instead of "freeze-drying". Even though, alcohol-dehydration technique followed by drying at low temperatures 
and pressures would be a valid process to reduce the hydroxyl bonding among precipitate particles and thus, particle-particle interaction during drying, as explained in section 2.5.1.

Another method commonly used to dry precursor particles is vacuum drying [38]. In this method, the ambient pressure is lowered, which creates a pressure gradient within the material. This is the primary driving force for moisture transfer. For this reason, vacuum drying is faster than conventional drying and the larger the pressure gradient, the faster the drying rate. During vacuum drying, solvent evaporates at a boiling temperature that depends on the partial pressure inside the chamber, and then the solvent vapor transfers from the material to ambient due to this pressure difference. The vacuum drying temperature can be lower than in conventional drying and operates at a temperature above the freezing point of the solvent [49].

On the other hand, the application of microwave for drying of ceramic precursors is still not sufficiently widespread in spite of its low operating cost, fast drying rate and no energy loss in the atmosphere [44]. The mechanism for microwave drying is fairly different from that of conventional oven drying. When conventional drying is carried out, the moisture is initially evaporated from the surface and the residual water diffuses slowly to the surface. In this case, the potential of energy transfer for heating is the temperature gradient, resulting in energy transfer to the internal part of the material, while the potential for mass transfer is the mass concentration gradient established between the wet interior and the dried surface [46]. In microwave drying, bulk heating occurs, in which the electromagnetic field interacts with the material as a whole entity. Due to internal heat generation, the mass transfer in microwave drying is the result of the total pressure gradient due to the rapid generation of vapor within the material. Insofar as the initial moisture in the material is higher, the influence of the pressure gradient on the total mass removal will be greater. This leads to quick drying without the necessity of heating the atmosphere [46]. Actually, the most evident effect of microwave drying is the considerable reduction in drying time, from more than $20 \mathrm{~h}$ for the alternative drying methods (conventional oven drying and freeze drying) to solely a few minutes [45].

Among the few works reported in the literature about the use of microwave drying of nanoparticles, the study carried out by $\mathrm{Yu}$ et al. [44] demonstrates that 
microwave drying allows obtaining smaller agglomerates of $\mathrm{TiO}_{2}$ after hydrothermal synthesis and overcomes conventional drying, even when ethanol washing of the as-synthesized $\mathrm{TiO}_{2}$ particles was accomplished before applying these two drying methods. These authors stated that the quick expansion of vapor within the wet colloidal nanoparticles causes the larger agglomerates to split into many smaller ones (breakage of large nanoparticle agglomerates), as illustrated in Figure 2.13 [44].
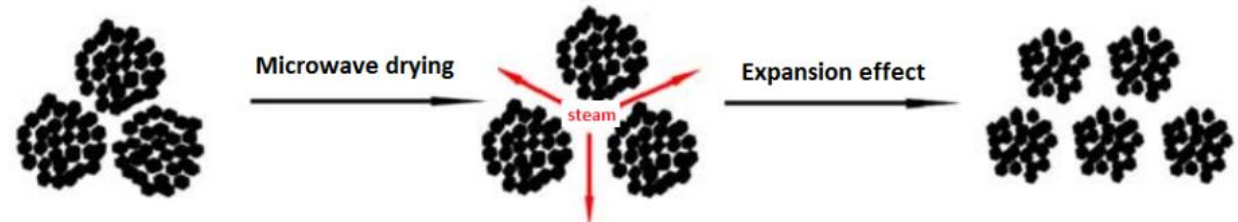

Figure 2.13- Scheme of an expansion mechanism caused by vapor within wet agglomerates during microwave drying.

\section{6. Polymer-based composites}

\subsection{1.} Applications of thermomiotics in polymer matrix composites

Among thermoplastics, high density polyethylene (HDPE) is one of the most versatile and used polyolefin, especially in geomembranes and pipes for water or gas transportation, where its high CTE can restrain the operating performance [50,51]. As a matter of fact, HDPE pipes can be used over a broad service temperature range, from $-10{ }^{\circ} \mathrm{C}$ to $70{ }^{\circ} \mathrm{C}$ [52], and the effects of expansion/contraction should be properly addressed to prevent and/or compensate thermal stresses that could compromise the structural integrity of a piping component, pipe joints or the structure which supports the pipe. Likewise, HDPE geomembranes can be exposed to landfill temperatures between $30-40{ }^{\circ} \mathrm{C}$, which may reach $60{ }^{\circ} \mathrm{C}$ in the presence of water. In this case, the thermal expansion of HDPE geomembranes usually results in wrinkles that could lead to material damage, premature failure and therefore, environmental degradation [52]. Hence, effort has been devoted to the development of HDPE-based composites with reduced and controlled thermal expansion. However, the application of 
thermomiotics in thermoplastic composites is still restricted and the fillers commonly used for the sake of controlling thermal expansion of the HDPE matrix are $\mathrm{CaCO}_{3}$, $\mathrm{Si}$, clays, fly ash, $\mathrm{CeO}_{2}$ and $\mathrm{Sr}_{2} \mathrm{Al}_{2} \mathrm{SiO}_{7}$ [1].

The thermomiotic phase most widely used for the preparation of polymer composites is $\mathrm{ZrW}_{2} \mathrm{O}_{8}$, due to its large isotropic negative thermal expansion [14], as stated above in Section 2.3. Very high volume percentages of $\mathrm{ZrW}_{2} \mathrm{O}_{8}$ up to 50 vol. \% have been mainly incorporated into thermosetting matrices to achieve CTE reductions from 15 to $70 \%$, depending on the matrix, filler size and surface modification of the filler (see Table 2.1).

Table 2.1- Polymer composites filled with particles exhibiting low positive and negative thermal expansion.

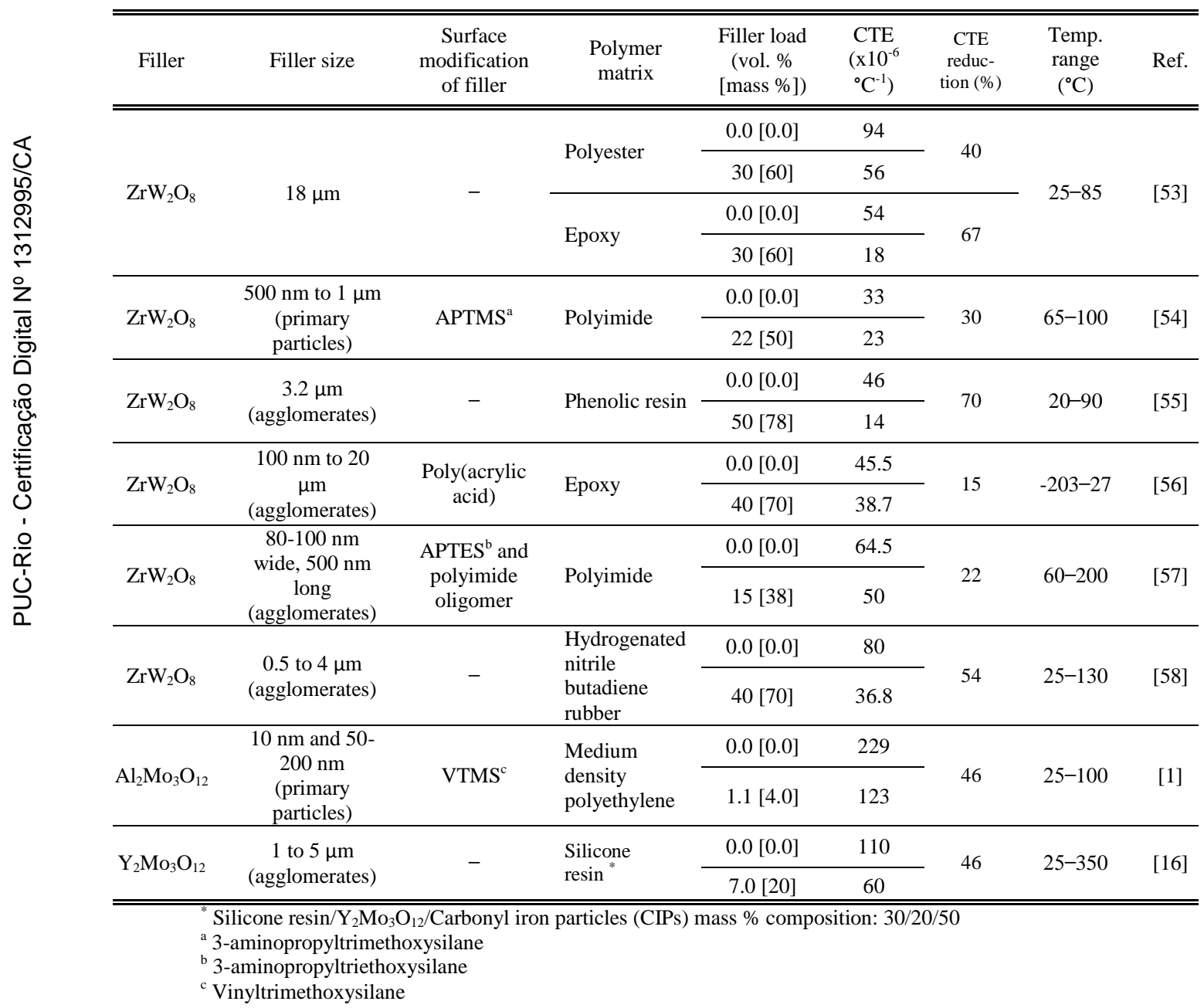

On the other hand, few works describe the use of $\mathrm{A}_{2} \mathrm{M}_{3} \mathrm{O}_{12}$ family members in polymer composites, as summarized in Table 2.1. Recently, medium density polyethylene-based composites reinforced with $\mathrm{Al}_{2} \mathrm{Mo}_{3} \mathrm{O}_{12}$ nanopowder, 
previously functionalized with VTMS, were prepared by melt compounding containing volume percentages of filler as low as $0.1-1.1$ vol. \%. The CTE of composites was reduced $\sim 46 \%$ with the addition of 1.1 vol. $\%$ of $\mathrm{Al}_{2} \mathrm{Mo}_{3} \mathrm{O}_{12}$. Furthermore, the Young's modulus and yield stress increased 19 and $6 \%$ at this filler fraction, respectively, when compared to the corresponding properties of the neat matrix, supporting the existence of strong filler-matrix interactions [1]. It is important to point out that the CTE reduction presented by those composites was accomplished using $\mathrm{Al}_{2} \mathrm{Mo}_{3} \mathrm{O}_{12}$ in the monoclinic phase $\left(\alpha_{l}=9.5 \times 10^{-6}{ }^{\circ} \mathrm{C}^{-1}\right.$, temperature range $-123-177{ }^{\circ} \mathrm{C}$ [17]) and for volume percentages of filler extremely low in comparison with those reported for $\mathrm{ZrW}_{2} \mathrm{O}_{8}$. The CTE of $\mathrm{Al}_{2} \mathrm{Mo}_{3} \mathrm{O}_{12}$ in the orthorhombic phase is lower $\left(\alpha_{l}=2.4 \times 10^{-6}{ }^{\circ} \mathrm{C}^{-1}\right)$ [17], but unfortunately this phase is stable solely at temperatures higher than $200{ }^{\circ} \mathrm{C}$, which constrains its application, considering that the processing temperatures of thermoplastics, such as HDPE, are lower than $200{ }^{\circ} \mathrm{C}$. Hence, $\mathrm{A}_{2} \mathrm{M}_{3} \mathrm{O}_{12}$ family members adoptiong the orthorhombic phase without undergoing phase transitions in a broad temperature range (at least, from room temperature to $200{ }^{\circ} \mathrm{C}$ ) are very promising fillers for HDPE-based composites. In this context, $\mathrm{Al}_{2} \mathrm{~W}_{3} \mathrm{O}_{12}$ and $\mathrm{Y}_{2} \mathrm{~W}_{3} \mathrm{O}_{12}$ are the ideal candidates that fulfill these two requirements. $\mathrm{Al}_{2} \mathrm{~W}_{3} \mathrm{O}_{12}$ possesses low positive thermal expansion $[2,6,59]\left(\alpha_{l}=1.75 \times 10^{-6}{ }^{\circ} \mathrm{C}^{-1}\right.$, measured in the temperature range between 25 and $800{ }^{\circ} \mathrm{C}$ ) [19], whilst $\mathrm{Y}_{2} \mathrm{~W}_{3} \mathrm{O}_{12}$ presents a negative thermal expansion $\left(\alpha_{l}=-7.0 \times 10^{-6}{ }^{\circ} \mathrm{C}^{-1}\right.$, in the temperature range between -258 and $\left.1100{ }^{\circ} \mathrm{C}\right)[6,60]$. The later phase is highly hygroscopic and forms a trihydrate monoclinic structure at room temperature $\left(\mathrm{Y}_{2} \mathrm{~W}_{3} \mathrm{O}_{12} .3 \mathrm{H}_{2} \mathrm{O}\right)$, but it does not suffer amorphization and water molecules can be easily withdrawn from the structure [61].

Another important thermomiotic phase, $\mathrm{Y}_{2} \mathrm{Mo}_{3} \mathrm{O}_{12}$, displays one of the strongest negative thermal expansion coefficients in $\mathrm{A}_{2} \mathrm{M}_{3} \mathrm{O}_{12}$ family $\left(\alpha_{l}=\right.$ $1.26 \times 10^{-5}{ }^{\circ} \mathrm{C}^{-1}$, temperature interval $130-900{ }^{\circ} \mathrm{C}$ ) and undergoes no phase transformation up to $-271{ }^{\circ} \mathrm{C}[62,63]$. Nonetheless, the wide channels in $\mathrm{Y}_{2} \mathrm{Mo}_{3} \mathrm{O}_{12}$ structure accommodate $\mathrm{H}_{2} \mathrm{O}$ molecules that are responsible for partial amorphization of this phase at room temperature [62]. In spite of the amorphization problems, $\mathrm{Y}_{2} \mathrm{Mo}_{3} \mathrm{O}_{12}$ thermally treated to assume its orthorhombic phase, has been used for the fabrication of carbonyl iron particles/silicon resin composites, where a mass $\%$ of the components $\mathrm{Y}_{2} \mathrm{Mo}_{3} \mathrm{O}_{12} /$ Carbonyl iron 
particles/silicon resin of 30/20/50 allowed obtaining a composite showing a CTE reduction of $\sim 46 \%$ [16]. It is noteworthy that 0.20 mass $\%$ of $\mathrm{Y}_{2} \mathrm{Mo}_{3} \mathrm{O}_{12}$ corresponds to 7 vol. \% of this phase, which is still higher than those filler contents reported for the fabrication of polymer composites using $\mathrm{Al}_{2} \mathrm{Mo}_{3} \mathrm{O}_{12}$ phase [1].

An efficient reduction and control of the thermal expansion of polymerbased composites without deterioration of mechanical properties can be achieved when deagglomerated fillers are well embedded and dispersed inside the matrix. However, inorganic fillers are hydrophilic (rich in - $\mathrm{OH}$ surface groups), whilst polyolefin polymers are hydrophobic, which gives rise to a poor of compatibility among them, affecting the interfacial interaction between composite components. Moreover, inorganic nanoparticles from $\mathrm{AM}_{2} \mathrm{O}_{8}$ and $\mathrm{A}_{2} \mathrm{M}_{3} \mathrm{O}_{12}$ thermomiotic families are usually assembled into secondary submicronic or micronic agglomerates, as a consequence of soft-chemistry routes, such as co-precipitation or hydrothermal synthesis and calcination stage as mention above in section 2.5.1. Thus, it is difficult to break agglomerates apart into primary particle sizes to achieve homogeneous and true nanosize dispersion of the fillers within the matrix during conventional composite manufacturing processes.

In order to improve compatibility (wettability) between inorganic thermomiotic fillers and polymer matrix, functionalization of fillers with silane coupling agents $[1,54,57]$ has been reported in the literature, as well as, the surface modification of fillers with poly(acrylic acid), see Table 2.1. It has been stated that these surface treatments contributed also to enhance the filler dispersion in polymer matrices [57]. The influence of surface modification of $\mathrm{ZrW}_{2} \mathrm{O}_{18}$ with either APTES or APTES-polyimide oligomer on mechanical properties and thermal expansion of polyimide composites was studied by Sharma et al. [57]. Albeit elastic moduli of composites were increased as a result of improved engineered interfaces, the CTEs of composites were not affected by the presence of the interface groups, suggesting that different mechanisms may govern mechanical and thermal expansion properties of composites. Besides, it has been revealed that primary particles size of $\mathrm{ZrW}_{2} \mathrm{O}_{8}$ do not strongly affect the CTE of composites [57], likely due to the presence of secondary agglomerates. However when nanofillers can be dispersed into individual primary particles/platelets with high aspect ratio, as evidenced in the case of organoclays, 
the primary particle size, which would be indeed the overall particle size, can play a critical role in thermal expansion behavior of composites and remarkable CTE reductions can be attained even at lower filler loadings (6 mass \%) compared to conventional composites [64]. Therefore, the homogeneous dispersion of fillers inside the matrix is likely the most important parameter to achieve outstanding mechanical and thermal expansion properties of polymer composites, but also, it is one of the most difficult challenges, especially to disperse fillers into primary particles.

\subsection{2.}

\section{Micromechanical models for prediction of CTE of polymer-based composites}

Several models to predict the CTE of composites have been proposed under some assumptions on the mechanical performance of matrix and fillers, such as rule of mixture (ROM), Turner's [65] and Schapery's [66] models. The equations of these models are listed in Table 2.2.

Table 2.2- Micromechanical models for prediction of CTE of composites.

\begin{tabular}{|c|c|c|c|}
\hline Model & Prediction & Eq. & Variables and parameters \\
\hline Rule of mixture & $\alpha_{c}=\alpha_{m}(1-\phi)+\alpha_{f} \phi$ & $(2.11)$ & $\begin{array}{l}\alpha_{c}=\text { CTE of composite } \\
\alpha_{m}=\text { CTE of matrix } \\
\alpha_{f}=\text { CTE of filler } \\
\phi=\text { volume fraction of filler }\end{array}$ \\
\hline $\begin{array}{l}\text { Turner's } \\
\text { model [65] }\end{array}$ & $\begin{array}{l}\alpha_{c}=\frac{\alpha_{m}(1-\phi) K_{m} \alpha_{m}+\phi K_{f} \alpha_{f}}{(1-\phi) K_{m}+\phi K_{f}} \\
\text { where, } \\
K_{m}=\frac{E_{m} G_{m}}{3\left(3 G_{m}-E_{m}\right)} \\
G_{m} \sim \frac{3}{8} E_{m}\end{array}$ & $\begin{array}{l}(2.13) \\
(2.14)\end{array}$ & $\begin{aligned} K_{m}= & \text { Bulk modulus of matrix } \\
& \text { calculated from Eq. }(2.13) \\
E_{m}= & \text { Young's modulus of matrix } \\
G_{m}= & \text { Shear modulus of matrix } \\
& \text { calculated from Eq. }(2.14) \\
K_{f}= & \text { Bulk modulus of filler }\end{aligned}$ \\
\hline \multirow{3}{*}{$\begin{array}{l}\text { Schapery's } \\
\text { model [66] }\end{array}$} & $\alpha_{c}^{l}=\alpha_{m}+\frac{K_{f}}{K_{c}^{u}} \frac{\left(K_{m}-K_{c}^{u}\right)\left(\alpha_{f}-\alpha_{m}\right)}{\left(K_{m}-K_{f}\right)}$ & $(2.15)$ & $\begin{aligned} \alpha_{c}^{l}, \alpha_{c}^{u}= & \text { Lower and upper } \\
& \text { bounds of CTE of } \\
& \text { composite }\end{aligned}$ \\
\hline & $\begin{array}{c}\alpha_{c}^{u}=\alpha_{m}+\frac{K_{f}}{K_{c}^{l}} \frac{\left(K_{m}-K_{c}^{l}\right)\left(\alpha_{f}-\alpha_{m}\right)}{\left(K_{m}-K_{f}\right)} \\
\text { where, }\end{array}$ & $(2.16)$ & $\begin{aligned} K_{c}^{l}, K_{c}^{u}= & \text { Lower and upper } \\
& \text { bounds of bulk } \\
& \text { modulus of composite }\end{aligned}$ \\
\hline & $\begin{array}{r}K_{c}^{\imath}=K_{m}+\frac{1}{\frac{1}{K_{f}-K_{m}}+\frac{3(1-\phi)}{3 K_{m}+4 G_{m}}} \\
K_{c}^{u}=K_{f}+\frac{1-\phi}{\frac{1}{K_{m}-K_{f}}+\frac{3(1-\phi)}{3 K_{f}+4 G_{f}}}\end{array}$ & $(2.17)^{\ddagger}$ & $\begin{array}{l}G_{m}=\text { Shear modulus of matrix } \\
G_{f}=\text { Shear modulus of filler }\end{array}$ \\
\hline
\end{tabular}

${ }^{\ddagger}$ Eq. 7 and Eq. 8 corresponds to Hashin-Shtrikman model [67]. 
The ROM can be considered as a first approximation in the absence of the interaction between fillers and matrix. On the contrary, Turner's model assumes a mechanical interaction between composite components and there is no restriction on the filler shape. In this model, CTE of composite depends on the volume fraction and the bulk modulus of each component (see Equation (2.12)) [65]. The element with the larger bulk modulus contributes more to the thermal expansion of the composite. Schapery's model is based on thermoelastic principles and consists of two equations to predict upper and lower bounds for the CTE of composites [66]. This model is usually considered as a more realistic estimation, since the inner stress emerging from differences between CTEs of filler and matrix is determined under the condition of minimum free energy [68]. All three models assumes perfect interfaces, therefore, discrepancies between experimental and predicted CTE values of composites are not surprising [68]. 


\section{3}

\section{Objectives}

\section{1.}

\section{General objective}

Prepare HDPE-based composites with improved mechanical properties and reduced thermal expansion through the incorporation of $\mathrm{Al}_{2} \mathrm{~W}_{3} \mathrm{O}_{12}$ and $\mathrm{Y}_{2} \mathrm{~W}_{3} \mathrm{O}_{12}$ submicronic powders in mass fractions up to 0.060 and 0.056 respectively, which corresponds to a volume fraction up to 0.011 .

\section{2.}

\section{Specific objectives}

Synthesize $\mathrm{Y}_{2} \mathrm{~W}_{3} \mathrm{O}_{12}$ submicronic powders via i) co-precipitation by mixing reactants, ii) modified reverse strike co-precipitation and assess the effect of the method on the agglomeration state of the as-synthesized powders.

Study the chemical composition of amorphous precursor of $\mathrm{Y}_{2} \mathrm{~W}_{3} \mathrm{O}_{12}$ for a better understanding of the fundamentals of the co-precipitation process.

Synthesize $\mathrm{Al}_{2} \mathrm{~W}_{3} \mathrm{O}_{12}$ submicronic powders via i) normal strike method, ii) co-precipitation by mixing reactants and evaluate the effects of tungsten source, synthesis $\mathrm{pH}$ and drying technique of precursors on the agglomeration state of calcined powders.

Manufacturing of HDPE-based composites filled with $\mathrm{Al}_{2} \mathrm{~W}_{3} \mathrm{O}_{12}$ and $\mathrm{Y}_{2} \mathrm{~W}_{3} \mathrm{O}_{12}$ submicronic powders, with similar particle sizes and added at the same volume fractions (0.01 to 0.11$)$, by micro-compounding.

Study the role of $\mathrm{Al}_{2} \mathrm{~W}_{3} \mathrm{O}_{12}$ and $\mathrm{Y}_{2} \mathrm{~W}_{3} \mathrm{O}_{12}$ particles in thermal expansion behavior of the as-prepared composites, as well as, in their mechanical and thermal properties. 
4

\section{A study of co-precipitation methods for the synthesis of $\mathrm{Y}_{2} \mathrm{~W}_{3} \mathrm{O}_{12}$ submicronic powders ${ }^{1}$}

\section{1. \\ Background}

Potential applications of $\mathrm{Y}_{2} \mathrm{~W}_{3} \mathrm{O}_{12}$ as NTE filler in the field of composites have triggered important research $[69,70]$, and created the driving force to develop new synthesis routes to obtain less agglomerated $\mathrm{Y}_{2} \mathrm{~W}_{3} \mathrm{O}_{12}$ powders and to achieve homogenous dispersion of the filler into the matrix.

$\mathrm{Y}_{2} \mathrm{~W}_{3} \mathrm{O}_{12}$ has been mainly synthesized by solid state reaction [3, 7, 49]. However, this method presents significant drawbacks, such as high calcination temperatures $\left(800-1100{ }^{\circ} \mathrm{C}\right)$, long processing times and, consequently, highly agglomerated micron sized-particles.

To avoid the re-agglomeration wet ball-milling using an organic solvent (toluene), of the starting binary oxides $\left(\mathrm{Y}_{2} \mathrm{O}_{3}\right.$ and $\left.\mathrm{WO}_{3}\right)$, before the solid state reaction, has been reported by Das et al. [71]. However, the average particle size has been estimated only by field-emission scanning electron microscopy (FEGSEM) for a $\mathrm{Y}_{2} \mathrm{~W}_{3} \mathrm{O}_{12}$ sample obtained after ball-milling of starting oxides for $10 \mathrm{~h}$ using a transmission ratio of -2.25 and a subsequent thermal treatment at $800{ }^{\circ} \mathrm{C}$, which were the synthesis conditions that led to a powder with micron-sized agglomerates and primary particles of few hundred nanometers. Thus, there is a lack of information about particle size measured by other more, representative and conclusive, techniques, such as laser diffraction (LD) or dynamic light scattering (DLS). On the other hand, the $\mathrm{Y}_{2} \mathrm{~W}_{3} \mathrm{O}_{12}$ phase was still obtained at high temperatures $\left(\sim 800^{\circ} \mathrm{C}\right)$ after extended milling times $(10 \mathrm{~h})[71]$.

The co-precipitation method, using aqueous solutions of yttrium nitrate $\left(\mathrm{Y}\left(\mathrm{NO}_{3}\right)_{3} \cdot x \mathrm{H}_{2} \mathrm{O}\right)$ and sodium tungstate $\left(\mathrm{Na}_{2} \mathrm{WO}_{4} \cdot 2 \mathrm{H}_{2} \mathrm{O}\right)$ as reactants, in absence and presence of ethylenediamine tetraacetic acid (EDTA), was reported by Xu et

${ }^{1}$ This chapter was adapted from P.I. Pontón, L.P. Prisco, A. Dosen, G.S. Faro, M.A.S. de Abreu, B.A. Marinkovic, Co-precipitation synthesis of $\mathrm{Y}_{2} \mathrm{~W}_{3} \mathrm{O}_{12}$ submicronic powder, Ceram. Int. (2017) 43, 5, 4222-4228 [84]. 
al. [72] to prepare an amorphous precipitate that was further hydrothermally treated to obtain crystalline $\mathrm{Y}_{2} \mathrm{~W}_{3} \mathrm{O}_{12}$ doped with $\mathrm{Eu}^{3+}$ for luminescent applications. A similar route was also proposed by Huang et al.[73] with the assistance of sodium dodecyl bezenesulfonate (SDBS) during co-precipitation process. In this case $\mathrm{Y}_{2} \mathrm{~W}_{3} \mathrm{O}_{12}$ doped with $\mathrm{Eu}^{3+}$ and other rare earths was obtained after calcination of the hydrothermally treated precipitates. However, the coprecipitation method itself using solely yttrium nitrate and sodium tungstate as the reactants to synthesize $\mathrm{Y}_{2} \mathrm{~W}_{3} \mathrm{O}_{12}$ has not been studied yet. Indeed, there is no information about the chemical composition of the amorphous precursor, its crystallization temperature, the primary particle size of the crystalline phase, and the state of agglomeration.

In the present study two co-precipitation methods to prepare $\mathrm{Y}_{2} \mathrm{~W}_{3} \mathrm{O}_{12}$ from aqueous solutions of $\mathrm{Y}\left(\mathrm{NO}_{3}\right)_{3} \cdot x \mathrm{H}_{2} \mathrm{O}$ and $\mathrm{Na}_{2} \mathrm{WO}_{4} \cdot 2 \mathrm{H}_{2} \mathrm{O}$ were carried out without a precipitant agent: (i) co-precipitation by mixing reactants (ii) modified reverse strike co-precipitation, to assess the effect of the co-precipitation method on the agglomeration degree of powders. Also, chemical composition of the amorphous precursors was thoroughly studied for a better understanding of the fundamentals of the co-precipitation processes. Furthermore, findings about the crystal system of hydrated $\mathrm{Y}_{2} \mathrm{~W}_{3} \mathrm{O}_{12}$ at room temperature, as well as, the influence of drying conditions on the bulk thermal expansion of $\mathrm{Y}_{2} \mathrm{~W}_{3} \mathrm{O}_{12}$ consolidated specimens are presented herein.

\section{2.}

\section{Materials and methods}

\subsubsection{Co-precipitation of $\mathrm{Y}_{2} \mathrm{~W}_{3} \mathrm{O}_{12}$ by mixing reactants}

Co-precipitation was carried out by mixing $0.1 \mathrm{M}$ aqueous solutions of $\mathrm{Y}\left(\mathrm{NO}_{3}\right)_{3} \cdot \mathrm{xH}_{2} \mathrm{O}$ (Alfa Aesar, 99\%) and $\mathrm{Na}_{2} \mathrm{WO}_{4} \cdot 2 \mathrm{H}_{2} \mathrm{O}$ (Sigma Aldrich, 99\%), as shown in Figure 4.1. A white precipitate immediately formed and the as-obtained suspension $(\mathrm{pH}=6.4)$ was stirred for $10 \mathrm{~min}$. Afterwards, the precipitate was recovered by centrifugation with a NT 810 centrifuge (Novatecnica, Piracicaba, Brazil) at $4000 \mathrm{rpm}$ and washed three times with anhydrous ethanol (Vetec, 99.9\%). The wet precipitate was cooled to $-70{ }^{\circ} \mathrm{C}$ during $24 \mathrm{~h}$, and vacuum dried at $-48{ }^{\circ} \mathrm{C}$ and $0.190 \mathrm{mbar}$ for $24 \mathrm{~h}$ in order to sublimate eventual water remains. 
Finally, the amorphous precursor was calcined at $640{ }^{\circ} \mathrm{C}$ for $30 \mathrm{~min}$, using a heating rate of $20^{\circ} \mathrm{Cmin}^{-1}$ in a Tubular Maitec-INTI FET 1600/H furnace (São Carlos, Brazil). This calcined sample was stored in a desiccator with silica gel for further characterization and denominated as $\mathrm{Y}_{2} \mathrm{~W}_{3} \mathrm{O}_{12}-\mathrm{A}$.

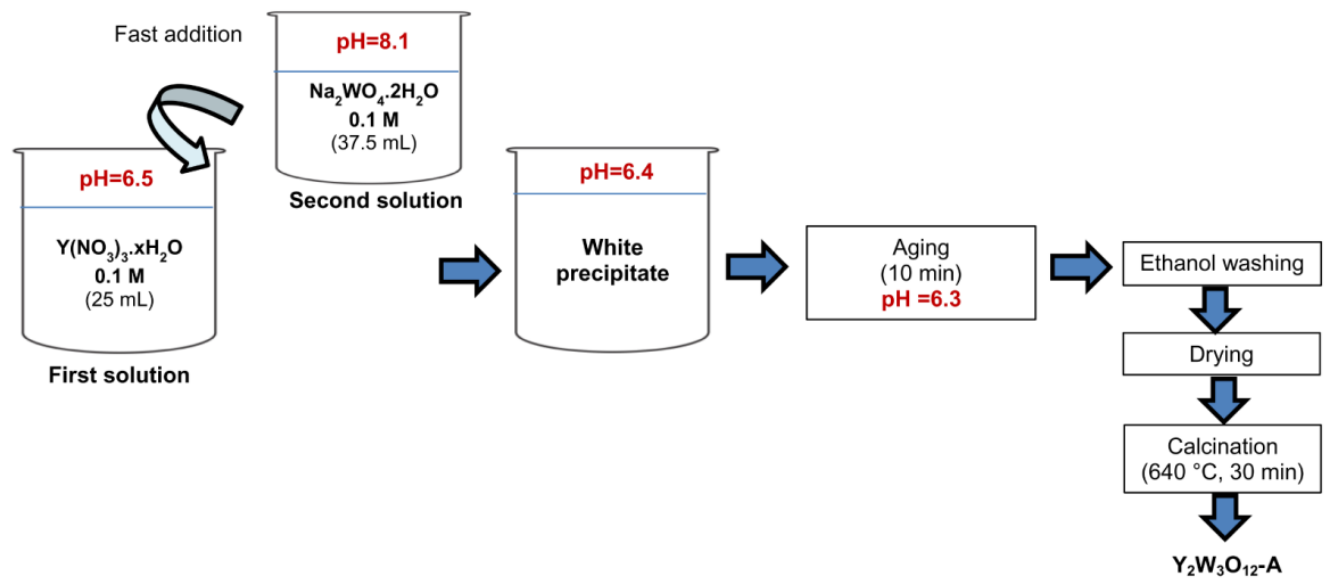

Figure 4.1- Schematic representation of the synthesis of $\mathrm{Y}_{2} \mathrm{~W}_{3} \mathrm{O}_{12}$ through co-precipitation by mixing reactants [84].

\subsection{2.}

\section{Co-precipitation of $\mathrm{Y}_{2} \mathrm{~W}_{3} \mathrm{O}_{12}$ by modified reverse strike co- precipitation}

The term "modified" was chosen to describe this synthesis route since sodium tungstate solution fulfilled the role of the basic solution instead of a precipitant agent, which is normally used in a typical reverse strike coprecipitation. Aqueous solutions of yttrium nitrate and sodium tungstate were prepared using the same reactants and molarity indicated above in section 4.2.1. The co-precipitation started immediately after dripping first drops of yttrium nitrate solution into sodium tungstate solution at a speed of 2-3 $\mathrm{mLmin}^{-1}$ under mild stirring, as depicted in Figure 4.2. After 10 min aging, the $\mathrm{pH}$ of the white suspension reached 6.5. Identical conditions to those detailed in the previous approach were used for recovery, washing, drying and calcination of the precipitate, as well as, storage of the calcined sample, which was denoted as $\mathrm{Y}_{2} \mathrm{~W}_{3} \mathrm{O}_{12}-\mathrm{B}$. 


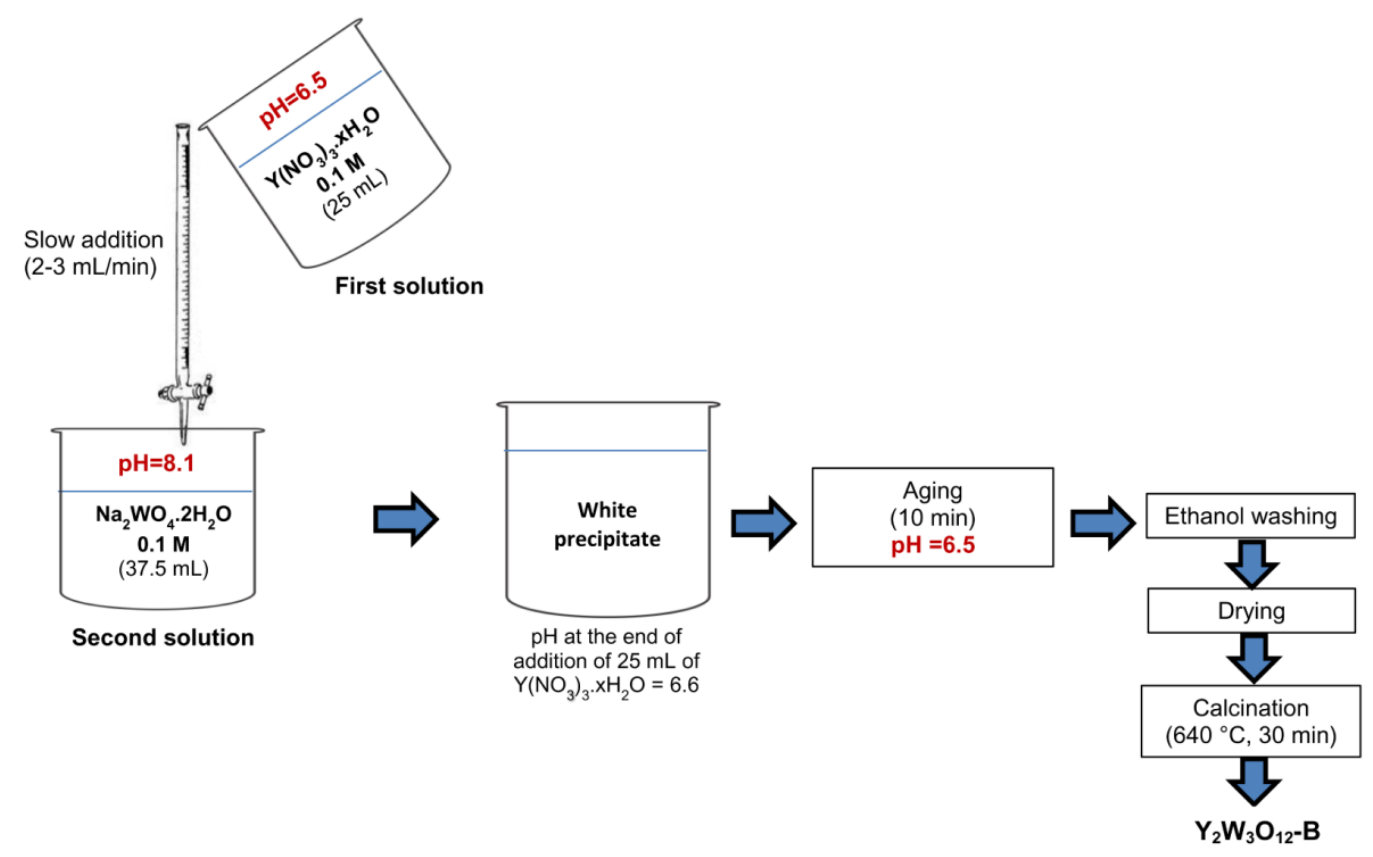

Figure 4.2- Schematic representation of the synthesis of $\mathrm{Y}_{2} \mathrm{~W}_{3} \mathrm{O}_{12}$ by modified reverse strike co-precipitation [84].

\subsection{3. \\ Characterization of $\mathrm{Y}_{2} \mathrm{~W}_{3} \mathrm{O}_{12}$ amorphous precursors and calcined powders}

The amorphous precursors were analyzed by differential scanning calorimetry (DSC) and thermogravimetry (TG) in a Perkin-Elmer Simultaneous Thermal Analyzer STA-6000 (Seer Green, U.K.), with a heating rate of $20{ }^{\circ} \mathrm{Cmin}^{-1}$ in air flow $\left(20 \mathrm{mLmin}^{-1}\right)$, for determination of the crystallization temperature of $\mathrm{Y}_{2} \mathrm{~W}_{3} \mathrm{O}_{12}$ and the mass losses of the precursors, respectively. Carbon, nitrogen, hydrogen $(\mathrm{CHN})$ elemental analyses of the precursors were performed in a Thermo Electron Corporation Flash EA 1112 Series (Delft, Netherlands) to verify whether the precursor is a hydroxide or hydroxynitrate. These samples were not washed with ethanol to avoid contamination and alteration of carbon content.

The calcined $\mathrm{Y}_{2} \mathrm{~W}_{3} \mathrm{O}_{12} \cdot n \mathrm{H}_{2} \mathrm{O}$ powders were analyzed by $\mathrm{X}$-ray powder diffraction (XRPD) at room temperature in a D8 Discover X-ray diffractomer (Bruker, Karlsruhe, Germany), using $\mathrm{CuK}_{\alpha}$ radiation in steps of $0.02^{\circ}$ ( $1 \mathrm{~s}$ per step) over a range of $10-80^{\circ} 2 \theta$. Data were collected using samples without drying. The $n$ values were computed based on mass losses between 60 and $120{ }^{\circ} \mathrm{C}$ 
[61], observed from thermogravimetric curves, obtained under the same conditions described for thermal analyses of the precursors.

The specific surface area and porosity of the as-synthesized powders was determined by BET nitrogen adsorption at $-196{ }^{\circ} \mathrm{C}$ using a TriStar 3000 V6.03 (Micromeritics, USA). Samples were pre-treated at $300{ }^{\circ} \mathrm{C}$ under vacuum of 50 mTorr. Moreover, the particle size distribution was measured by laser diffraction, using a dry feed system in a Malvern Mastersizer 2000 (Malvern Instruments Ltd., Worcestershire, U.K.). FE-SEM was performed in a JSM-6701F equipment (JEOL, Tokyo, Japan) in secondary electron mode operating at $1 \mathrm{kV}$ to study the morphology and size of the $\mathrm{Y}_{2} \mathrm{~W}_{3} \mathrm{O}_{12}$ agglomerates.

\subsection{4.}

\section{Characterization of $\mathrm{Y}_{2} \mathrm{~W}_{3} \mathrm{O}_{12}$ bulk ceramic}

Green bodies of the as-synthesized powders were pressed at $100 \mathrm{MPa}$ of uniaxial pressure for $1 \mathrm{~min}$. Dilatometry of these bulk specimens were carried out in air using a NETZSCH dilatometer DIL 402C (Selb, Germany) in the temperature range between 30 and $600^{\circ} \mathrm{C}$, with a heating rate of $10^{\circ} \mathrm{Cmin}^{-1}$, while the cooling rate was not controlled. The dilatometric curves of bulk specimens, consolidated from $\mathrm{Y}_{2} \mathrm{~W}_{3} \mathrm{O}_{12}$-B powder, were obtained after oven drying at $170{ }^{\circ} \mathrm{C}$ for (i) 2 days, (ii) 5 days and (iii) 10 days.

\section{3. \\ Results and discussions}

\subsection{1. Co-precipitation of the amorphous precursors and their chemical composition}

The co-precipitation by mixing reactants occurs since the $\mathrm{pH}$ of sodium tungstate solution is high enough to induce the supersaturation state and the coprecipitation of $\mathrm{Y}_{2} \mathrm{~W}_{3} \mathrm{O}_{12}$ amorphous precursor without the addition of a precipitant agent. The $\mathrm{pH}$ at the end of this process is 6.4 and the amorphous white precipitate is formed rapidly when the two solutions of reactants are in contact [24]. On the other hand, one of the theoretical advantages of the modified reverse strike co-precipitation could be a much higher $\mathrm{pH}$ value $(\mathrm{pH}=8.1)$ at 
which process starts. This assures that the solubility product $\left(\mathrm{K}_{\mathrm{sp}}\right)$ of the precipitate is always, and highly, exceeded [24,25]. As a result, the supersaturation level is much higher than that of co-precipitation by mixing reactants. The variation of $\mathrm{pH}$ during the modified reverse strike co-precipitation of $\mathrm{Y}_{2} \mathrm{~W}_{3} \mathrm{O}_{12}$ precursor is shown in Figure 4.3. This method is time-consuming in comparison with the previous approach.

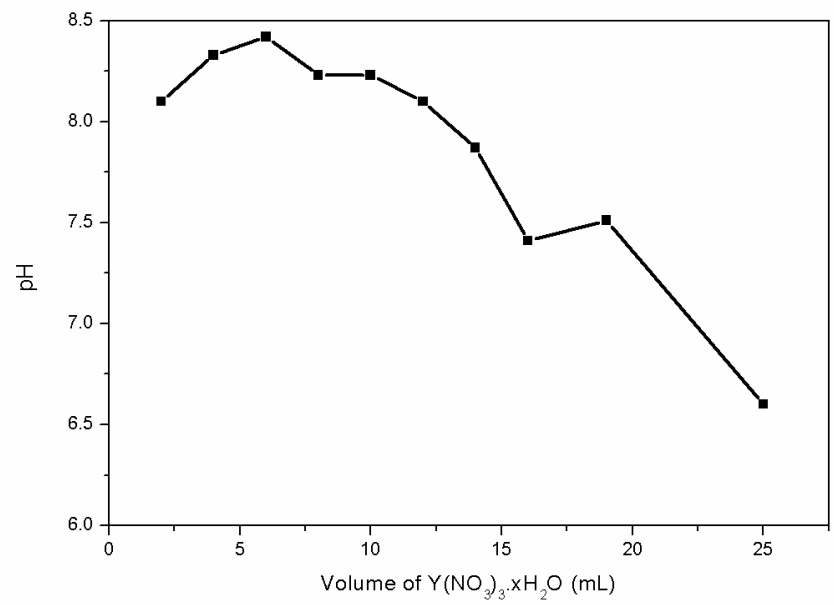

Figure 4.3- Variation of the $\mathrm{pH}$ during the modified reverse strike co-precipitation of $\mathrm{Y}_{2} \mathrm{~W}_{3} \mathrm{O}_{12}$ precursor (dripping speed of yttrium nitrate solution: 2-3 $\mathrm{mLmin}^{-1}$ ) [84].

It is worth noting that the nucleation rate increases exponentially with the level of supersaturation, while the growth rate is approximately a linear function of supersaturation (see Equations (2.3) and (2.5) in section 2.4.1). Thus, high supersaturation levels reached in the modified reverse strike co-precipitation would promote nucleation rate, rather than crystallite growth, and the formation of fine precipitates $[24,74]$. Therefore, in theory it should be expected that modified reverse strike co-precipitation allows for the synthesis of less agglomerated particles, when compared with the co-precipitation by mixing reactants, which occurs at lower $\mathrm{pH}$ value and lower saturation levels, as stated before in Section 2.4.1.

An approximate chemical composition of the amorphous precursors $\left(\mathrm{pY}_{2} \mathrm{~W}_{3} \mathrm{O}_{12}\right.$ ) was estimated based on $\mathrm{CHN}$ results (Table 4.1), thermogravimetric curves of precursors (Appendix A, Figure A.1) and charge neutrality principle. 
Table 4.1- $\mathrm{CHN}$ results of $\mathrm{Y}_{2} \mathrm{~W}_{3} \mathrm{O}_{12}$ amorphous precursors [84].

\begin{tabular}{cccc}
\hline Sample & $\begin{array}{c}\text { Nitrogen } \\
(\text { mass \%) }\end{array}$ & $\begin{array}{c}\text { Carbon } \\
(\text { mass \%) }\end{array}$ & $\begin{array}{c}\text { Hydrogen } \\
(\text { mass \%) }\end{array}$ \\
\hline $\mathrm{pY}_{2} \mathrm{~W}_{3} \mathrm{O}_{12}-\mathrm{A}$ & 0.8 & - & 1.4 \\
$\mathrm{pY}_{2} \mathrm{~W}_{3} \mathrm{O}_{12}-\mathrm{B}$ & 0.8 & - & 1.8 \\
\hline
\end{tabular}

The composition of both precursors is similar and could correspond to a hydroxynitrate or oxyhydroxynitrate compounds. The only difference between them is the mass percentage of hydrogen, attributed to $\mathrm{OH}^{-}$groups and water molecules. Since the precursor is highly hydroscopic the amount of water molecules also depends on the storage conditions. Therefore, the mass percentage of hydrogen was not considered for calculating the composition of the precursor. Three hypothetical formulae were proposed and evaluated, taking into account the likely ionic species that could be part of the precursors:

- $\mathrm{Y}_{2}(\mathrm{OH})_{\mathrm{Z}}\left(\mathrm{NO}_{3}\right)_{\mathrm{x}}\left(\mathrm{WO}_{4}\right)_{\mathrm{u}} \cdot n \mathrm{H}_{2} \mathrm{O}$

- $\mathrm{Y}_{2} \mathrm{~W}_{3}(\mathrm{OH})_{\mathrm{z}}\left(\mathrm{NO}_{3}\right)_{\mathrm{x}} \cdot n \mathrm{H}_{2} \mathrm{O}$

- $\mathrm{Y}_{2} \mathrm{~W}_{3} \mathrm{O}_{\mathrm{y}}(\mathrm{OH})_{\mathrm{z}}\left(\mathrm{NO}_{3}\right)_{\mathrm{x}} \cdot n \mathrm{H}_{2} \mathrm{O}$

A thorough analysis of the proposed formulae of precursors is presented in Appendix A. The number of water molecules $(n)$ was calculated from TGA curves of the precursors (see Appendix A, Figure A.1). The subscripts were computed from the equation of the charge neutrality of the compound, the equation of the molecular weight of the precursor (which is related with the total mass loss of the precursor that corresponds to the formation of $\mathrm{Y}_{2} \mathrm{~W}_{3} \mathrm{O}_{12}$ ) and nitrogen percentage. The formula that matches the experimental results is the third one. Therefore, the approximate composition of precursors A and B is $\mathrm{Y}_{2} \mathrm{~W}_{3} \mathrm{O}_{9.15}(\mathrm{OH})_{5.08}\left(\mathrm{NO}_{3}\right)_{0.62} \cdot 4.35 \mathrm{H}_{2} \mathrm{O}$ and $\mathrm{Y}_{2} \mathrm{~W}_{3} \mathrm{O}_{9.42}(\mathrm{OH})_{4.53}\left(\mathrm{NO}_{3}\right)_{0.62} \cdot 5.88 \mathrm{H}_{2} \mathrm{O}$, respectively.

In aqueous solution, yttrium exists in the trivalent state $\left(\mathrm{Y}^{3+}\right)$ and it is strongly hydrated. Based on hydrolyzing speciation diagram of $\mathrm{Y}^{3+}$ (see Appendix A, Figure A.2) the main specie at $\mathrm{pH}=6.5$ is $\mathrm{Y}\left(\mathrm{H}_{2} \mathrm{O}\right)_{8}{ }^{3+}$ [75]. However, $\mathrm{Y}(\mathrm{OH})\left(\mathrm{H}_{2} \mathrm{O}\right)_{6}{ }^{2+}$ also exists in the solution at this $\mathrm{pH}$ in a lower fraction. When the $\mathrm{pH}$ is raised to near $8, \mathrm{Y}(\mathrm{OH})_{2}\left(\mathrm{H}_{2} \mathrm{O}\right)_{5}{ }^{+}$is formed and coexists with other two species [75]. Thus, it is expected that $\mathrm{OH}^{-}$groups and $\mathrm{H}_{2} \mathrm{O}$ molecules are present in the precipitated precursors. However, in the specific case of $\mathrm{Y}\left(\mathrm{NO}_{3}\right)_{3}$ aqueous 
solutions, $\mathrm{Y}^{3+}$ can be coordinated not only by $\mathrm{H}_{2} \mathrm{O}$ molecules, but also by nitrate ions to form nitrate-complexes such as $\left[\mathrm{Y}\left(\mathrm{H}_{2} \mathrm{O}\right)_{8-\mathrm{p}}\left(\mathrm{NO}_{3}\right)_{\mathrm{p}}\right]^{+3-\mathrm{p}}$, which almost disappeared when the solution concentration is lower than $0.1 \mathrm{M}$ [76]. Hence, the presence of $\mathrm{NO}_{3}{ }^{-}$groups in both precursors is also expected.

Considering the speciation diagram of $\mathrm{W}^{6+}$ from $\mathrm{Na}_{2} \mathrm{WO}_{4}$ aqueous solution $(0.1 \mathrm{M})$ the major specie at $\mathrm{pH}>7.8$ is $\left(\mathrm{WO}_{4}\right)^{2-}$, while polytungstate species are formed starting from $\mathrm{pH} \leq 7.8$ and become the major species in solutions below pH 7.15 [77] (see Appendix A, Figure A.3). The two more predominant polyanions are the so-called paratungstate $\mathrm{A}$ and $\mathrm{B},\left(\mathrm{W}_{7} \mathrm{O}_{24}\right)^{6-}$ and $\left(\mathrm{H}_{2} \mathrm{~W}_{12} \mathrm{O}_{42}\right)^{10-}$, respectively, which can coexist from $\mathrm{pH}=7.8$ to $\mathrm{pH}=5$ [77]. At $\mathrm{pH}=6.8$, next to the final $\mathrm{pH}$ values obtained by the two co-precipitation methods applied in this work, the main specie reported in the literature is $\left(\mathrm{W}_{7} \mathrm{O}_{24}\right)^{6-}[78]$. However, this tungstate polyanion cannot be easily isolated from solution unless special cautions are carried out. This polyanion is labile and can be dissociated into $\left(\mathrm{W}_{6} \mathrm{O}_{19}\right)^{2-}$ species. Actually, $\left(\mathrm{W}_{12} \mathrm{O}_{42}\right)^{12-}$ specie from paratungstate $\mathrm{B}$ is usually the solid form isolated from solution at $\mathrm{pH} \sim 7$ [78]. Therefore, the precipitate species may not necessarily represent the species with the highest abundance in solution [78]. Taking into account the proposed chemical formulae of precursors $\mathrm{A}$ and $\mathrm{B}$, the ratio $\mathrm{O} / \mathrm{W}$ is similar to that of $\left(\mathrm{W}_{6} \mathrm{O}_{19}\right)^{2-}$ polyanion, which suggest that this specie might be part of the precipitated precursors. Due to the complex formation of polytungstate species and their complicated isolation from the solution, it is not possible to state whether a specific polytungstate anion or a mixture of them exists in the amorphous precursors and this issue is beyond the scope of this work.

We proposed for the first time a chemical formula of a precursor of $\mathrm{A}_{2} \mathrm{M}_{3} \mathrm{O}_{12}$ family for a better understanding of the co-precipitation mechanism. In this case, the precipitate formed is an oxyhydroxynitrate compound that presents less $\mathrm{OH}^{-}$groups than a pure hydroxide one. As a result, the possibility of hydroxyl bonding, during drying and calcination, is decreased and this could cause a less agglomerated powder [39].

Furthermore, the chemical compositions of precursors A and B are in agreement with the fact that the ratio between hydroxyl groups $\left(\mathrm{OH}^{-}\right)$and rare earth cations $\left(\mathrm{Re}^{3+}\right)$ or yttrium in the precipitate composition is generally in the range from 2.5 to 3.0 [25]. The ratio of $\mathrm{OH}^{-} / \mathrm{Y}^{3+}$ for $\mathrm{pY}_{2} \mathrm{~W}_{3} \mathrm{O}_{12}-\mathrm{A}$ was 2.5, while 
for $\mathrm{pY}_{2} \mathrm{~W}_{3} \mathrm{O}_{12} \mathrm{~B}$ was slightly lower (2.3). Indeed, the ratios $\mathrm{OH}^{-} / \mathrm{Y}^{3+}$ and $\mathrm{NO}^{3-}$ $/ \mathrm{Y}^{3+}$ of the precursors are similar to those of yttrium hydroxynitrate $\left(\mathrm{Y}(\mathrm{OH})_{2.5}\left(\mathrm{NO}_{3}\right)_{0.5}\right)$. Since $K_{s p}$ values of the synthesized precursors are unknown, $K_{s p}$ of $\mathrm{Y}(\mathrm{OH})_{2.5}\left(\mathrm{NO}_{3}\right)_{0.5}$ could be a useful approach to estimate the initial $\mathrm{pH}$ for co-precipitation of the precursors. Thus, the formation of $\mathrm{Y}(\mathrm{OH})_{2.5}\left(\mathrm{NO}_{3}\right)_{0.5}$ can be expressed by the following equilibrium reaction:

$\mathrm{Y}^{3+}+2.5 \mathrm{OH}^{-}+0.5 \mathrm{NO}_{3}{ }^{-} \rightleftharpoons \mathrm{Y}(\mathrm{OH})_{2.5}\left(\mathrm{NO}_{3}\right)_{0.5} \quad K_{s p}=1.5 \times 10^{-20}$

Considering the $K_{s p}$ of yttrium hydroxynitrate [79] and the concentrations of yttrium $\left[\mathrm{Y}^{3+}\right]$ and nitrate $\left[\mathrm{NO}_{3}{ }^{-}\right]$ions in the reaction solution $(0.1 \mathrm{M})$, the $\mathrm{pH}$ to attain a saturated solution is calculated to be 6.7. Hence, $\mathrm{pH}$ values higher than 6.7 give rise to supersaturation levels high enough to promote $\mathrm{Y}(\mathrm{OH})_{2.5}\left(\mathrm{NO}_{3}\right)_{0.5}$ precipitation from solution. In the case of synthesis A, the formation of precipitate occurred at a $\mathrm{pH}(6.4)$, slightly lower than that for pure $\mathrm{Y}(\mathrm{OH})_{2.5}\left(\mathrm{NO}_{3}\right)_{0.5}$ due to the fact that a $\mathrm{W}^{6+}$ specie, possibly $\left(\mathrm{W}_{6} \mathrm{O}_{19}\right)^{2-}$, is co-precipitated with $\mathrm{Y}^{3+}$ in a polyanion form, whilst the $\mathrm{pH}$ at the end of the synthesis $\mathrm{B}$ was 6.60 .

The effect of the co-precipitation method on crystallization temperature of the amorphous precursors can be inferred from DSC curves shown in Figure 4.4, where the crystallization peak of $\mathrm{pY}_{2} \mathrm{~W}_{3} \mathrm{O}_{12}-\mathrm{B}$ is slightly shifted towards lower temperatures (Figure 4.4b), which could be rationalized through a smaller fraction of $\mathrm{OH}^{-}$groups in this precursor. Albeit this small difference in the crystallization temperature, both precursors were calcined at $640{ }^{\circ} \mathrm{C}$ to avoid the influence of calcination temperature on the particle size of $\mathrm{Y}_{2} \mathrm{~W}_{3} \mathrm{O}_{12}$ powders. It is important to point out that an advantage of these co-precipitation methods is that crystalline $\mathrm{Y}_{2} \mathrm{~W}_{3} \mathrm{O}_{12}$ is obtained at a calcination temperature at least $160{ }^{\circ} \mathrm{C}$ lower than the temperatures required in solid state synthesis, contributing to less agglomerated powders. The percent yield of the chemical reaction to produce $\mathrm{Y}_{2} \mathrm{~W}_{3} \mathrm{O}_{12}$ crystalline powders was $100 \%$ for both co-precipitation methods. 

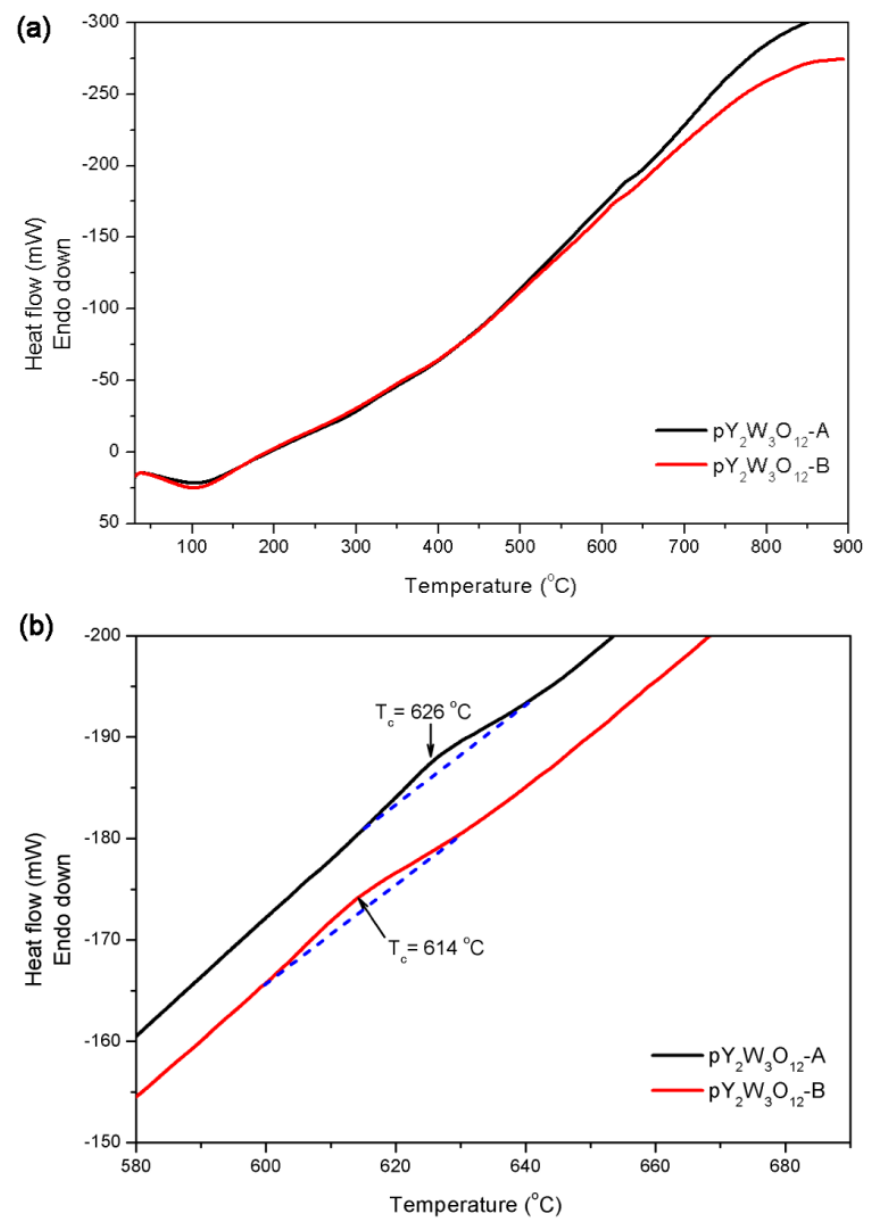

Figure 4.4- DSC curves of the as-prepared $\mathrm{Y}_{2} \mathrm{~W}_{3} \mathrm{O}_{12}$ amorphous precursors in the temperature range of (a) 30 to $900{ }^{\circ} \mathrm{C}$ and (b) 580 to $680{ }^{\circ} \mathrm{C}$. Exothermic peaks are due crystallization of $\mathrm{Y}_{2} \mathrm{~W}_{3} \mathrm{O}_{12}$ [84].

\subsection{2.}

\section{Crystal system of hydrated $\mathrm{Y}_{2} \mathrm{~W}_{3} \mathrm{O}_{12}$ and the bulk thermal expansions} of $\mathrm{Y}_{2} \mathrm{~W}_{3} \mathrm{O}_{12}$ exposed to different drying conditions

TG curves of crystalline samples of $\mathrm{Y}_{2} \mathrm{~W}_{3} \mathrm{O}_{12}-\mathrm{A}$ and $\mathrm{Y}_{2} \mathrm{~W}_{3} \mathrm{O}_{12}-\mathrm{B}$ without drying are shown in Figure A.4 (see Appendix A). The hydration degree ( $n$ ) was calculated as the mass loss between 60 and $120^{\circ} \mathrm{C}$, as suggested by Sumithra and Umarji [61]. Further mass loss above $120{ }^{\circ} \mathrm{C}$ is ascribed to dehydroxylation process. The $n$ value for samples $\mathrm{Y}_{2} \mathrm{~W}_{3} \mathrm{O}_{12}-\mathrm{A}$ and $\mathrm{Y}_{2} \mathrm{~W}_{3} \mathrm{O}_{12}-\mathrm{B}$ was 2.70 and 2.50 water molecules, respectively.

XRPD pattern of $\mathrm{Y}_{2} \mathrm{~W}_{3} \mathrm{O}_{12}$ - $\mathrm{B}$ hydrated powder $\left(n=2.5 \mathrm{H}_{2} \mathrm{O}\right)$ is presented in Figure 4.5. Le Bail adjustment of calculated diffraction profiles to experimental patterns indicated presence of predominantly monoclinic $(P 2 / m)$ phase. XRPD 
pattern of $\mathrm{Y}_{2} \mathrm{~W}_{3} \mathrm{O}_{12}$-A hydrated powder $\left(n=2.7 \mathrm{H}_{2} \mathrm{O}\right)$ is not presented since it is practically identical to the one presented in Figure 4.5.

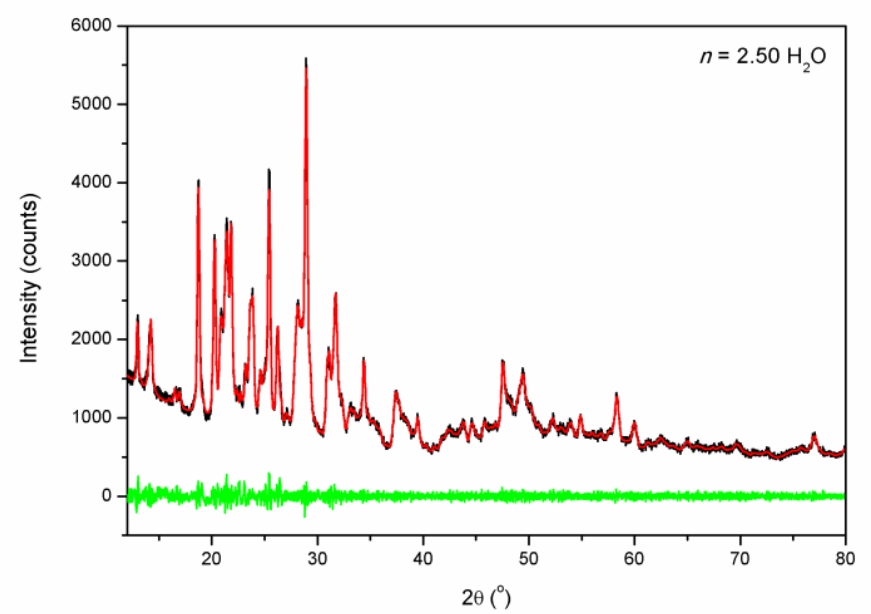

Figure 4.5- Room-temperature XRPD patterns and Le Bail fitting of $\mathrm{Y}_{2} \mathrm{~W}_{3} \mathrm{O}_{12}-\mathrm{B} \cdot 2.50 \mathrm{H}_{2} \mathrm{O}$ powder without drying. The experimental pattern is black, the calculated pattern is red and the difference plot is green [84].

The crystal system of $\mathrm{Y}_{2} \mathrm{~W}_{3} \mathrm{O}_{12} .3 \mathrm{H}_{2} \mathrm{O}$ at room temperature has been reported as orthorhombic by Sumithra and Umarji [61]. However, Sleight [80] stated that this trihydrated phase can be indexed with a monoclinic cell $(P 2 / m)$ and observed a $7 \%$ decrease in the unit cell volume compared to unhydrated $\mathrm{Y}_{2} \mathrm{~W}_{3} \mathrm{O}_{12}$ phase. This monoclinic cell can be converted to a pseudo-orthorhombic phase, which is comparable to unhydrated $\mathrm{Y}_{2} \mathrm{~W}_{3} \mathrm{O}_{12}$ orthorhombic phase at room temperature [80]. On the other hand, Kol tsova [81] claimed that trihydrated form of $\mathrm{Y}_{2} \mathrm{~W}_{3} \mathrm{O}_{12}$ exhibits a monoclinic structure $(P 2 / m)$, but with cell parameters different to those reported by Sleight [80], while Koh et al.[82] pointed out that XRPD patterns of hydrated $\mathrm{Y}_{2} \mathrm{~W}_{3} \mathrm{O}_{12}$ do not show exact matches to either orthorhombic or monoclinic phase. Thus, $\mathrm{Y}_{2} \mathrm{~W}_{3} \mathrm{O}_{12}$ may exist in the orthorhombic phase (unhydrated form), monoclinic (hydrated form) phase or in a mixed phase state depending on the hydration degree [82]. In this work, $\mathrm{Y}_{2} \mathrm{~W}_{3} \mathrm{O}_{12}$ is mainly in monoclinic phase (with the space group $P 2 / m$ and similar unit-cell parameters to those reported by Sleight [80]: $a=16.7267 \AA, b=10.0449 \AA, c=19.2045 \AA$, $\beta=126.91^{\circ}$ ) with average crystallites of $44 \mathrm{~nm}$ as demonstrated for $\mathrm{Y}_{2} \mathrm{~W}_{3} \mathrm{O}_{12}$ - $\mathrm{B}$. Le Bail adjustment of XRPD pattern of $\mathrm{Y}_{2} \mathrm{~W}_{3} \mathrm{O}_{12}-\mathrm{A} \cdot 2.70 \mathrm{H}_{2} \mathrm{O}$ also demonstrated the existence of predominantly monoclinic $(P 2 / m)$ phase with average crystallites of approximately $50 \mathrm{~nm}$. 
A study of the bulk thermal expansion of $\mathrm{Y}_{2} \mathrm{~W}_{3} \mathrm{O}_{12}-\mathrm{B}$ specimens with different hydration degree was performed to verify XRPD findings that monoclinic crystal system is the stable one at room temperature for hydrated $\mathrm{Y}_{2} \mathrm{~W}_{3} \mathrm{O}_{12}$ phase. Dilatometric curves of green $\mathrm{Y}_{2} \mathrm{~W}_{3} \mathrm{O}_{12}-\mathrm{B}$ consolidated specimens were obtained after drying at $170{ }^{\circ} \mathrm{C}$ for 2,5 days and 10 days, respectively, as illustrated in Figure 4.6.

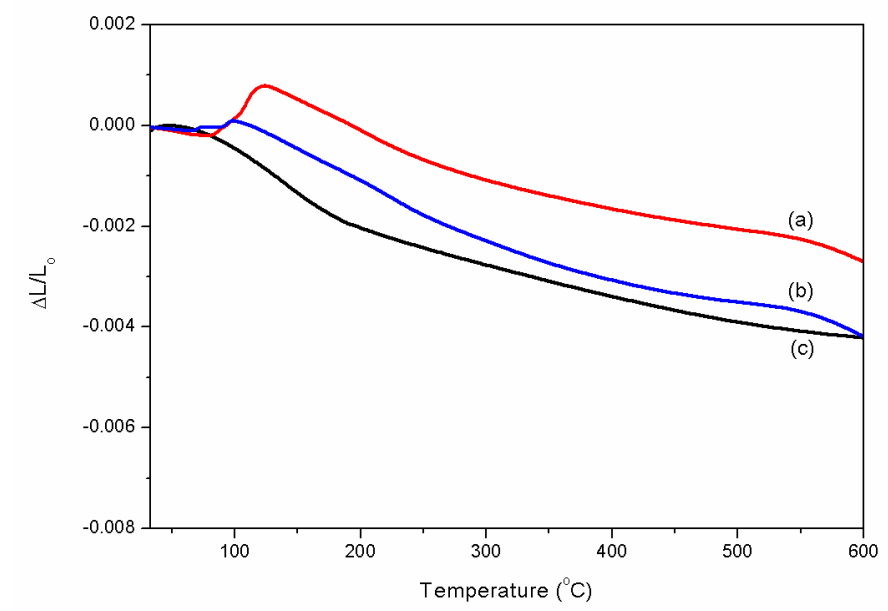

Figure 4.6- Dilatometric curves of bulk specimens consolidated from $\mathrm{Y}_{2} \mathrm{~W}_{3} \mathrm{O}_{12}$-B obtained after oven drying at $170{ }^{\circ} \mathrm{C}$ for (a) 2 days, (b) 5 days, and (c) 10 days and third heating cycle in dilatometer [84].

The dilatometric curve of monolithic $\mathrm{Y}_{2} \mathrm{~W}_{3} \mathrm{O}_{12}-\mathrm{B}$, dried for 2 days at 170 ${ }^{\circ} \mathrm{C}$, presents a small initial contraction up to $60{ }^{\circ} \mathrm{C}$ followed by an expansion until $120^{\circ} \mathrm{C}$. Sumithra and Umarji [61] attributed this expansion feature to elimination of water molecules. However, this expansion is not only related to the removal of water from the structure but also to the transition from monoclinic to orthorhombic phase, since orthorhombic phase possesses a larger unit cell than monoclinic one. Similarly, $\mathrm{Y}_{2} \mathrm{~W}_{3} \mathrm{O}_{12}-\mathrm{B}$ bulk specimen dried at $170{ }^{\circ} \mathrm{C}$ for 5 days shows an initial contraction up to $60{ }^{\circ} \mathrm{C}$ followed by a slight expansion until 100 ${ }^{\circ} \mathrm{C}$, which means that water molecules and consequently monoclinic phase are still present, although in a smaller amounts. The bulk CTEs of monolithic $\mathrm{Y}_{2} \mathrm{~W}_{3} \mathrm{O}_{12}-\mathrm{B}$ previously dried at $170{ }^{\circ} \mathrm{C}$ for 2 and 5 days, respectively, were calculated in the range of $150-600{ }^{\circ} \mathrm{C}$ and the values were: $-6.23 \times 10^{-6}$ and $-7.50 \times 10^{-6}{ }^{\circ} \mathrm{C}^{-1}$ for each specimen. These values are similar to the intrinsic $\alpha_{l}[5,6]$. In the case of 
$\mathrm{Y}_{2} \mathrm{~W}_{3} \mathrm{O}_{12}-\mathrm{B}$ bulk specimen dried at $170{ }^{\circ} \mathrm{C}$ during 10 days, and after the third heating cycle in dilatometer, the initial expansion practically disappears and CTE computed in the range of $30-600{ }^{\circ} \mathrm{C}$ was $-7.70 \times 10^{-6}{ }^{\circ} \mathrm{C}^{-1}$, which matches the $\alpha_{l}$ of the orthorhombic phase.

\subsection{3.}

\section{Effects of co-precipitation methods on agglomeration of calcined $\mathrm{Y}_{2} \mathrm{~W}_{3} \mathrm{O}_{12}$ powders}

The particle size distribution curves in number of both synthesized powders obtained by laser diffraction are shown in Figure 4.7. It is worth noting that the nanometric fraction of particles cannot be detected by this technique.

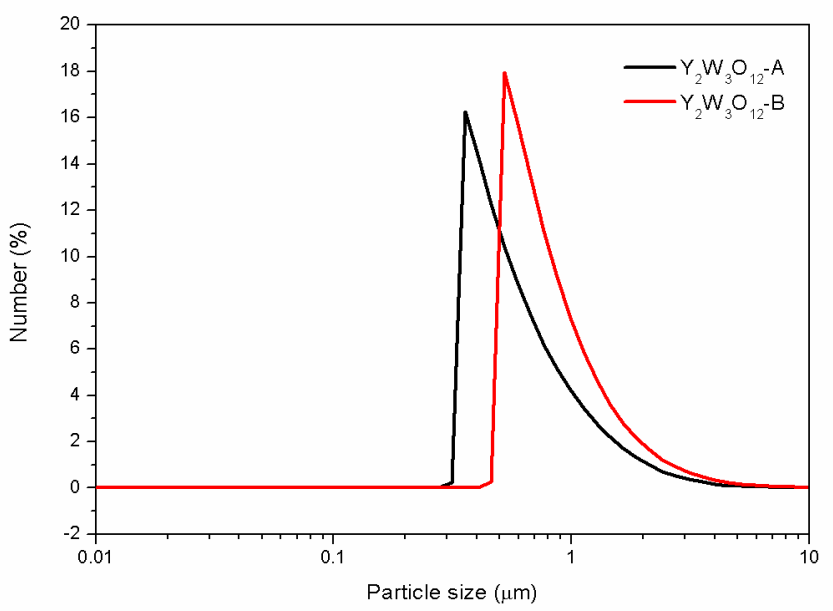

Figure 4.7- Particle size distribution in number of the as-prepared $\mathrm{Y}_{2} \mathrm{~W}_{3} \mathrm{O}_{12}$ powders measured by laser diffraction [84].

The specific surface area $\left(\mathrm{S}_{\mathrm{BET}}\right)$ of the as-prepared $\mathrm{Y}_{2} \mathrm{~W}_{3} \mathrm{O}_{12}$ powders is shown in Table 4.2, as well as, the primary particle size calculated from $\mathrm{S}_{\mathrm{BET}}$ $\left(d_{B E T}\right)$ and the median diameter obtained from particle size distribution in number of particles $\left(d_{50}\right)$. $\mathrm{d}_{\mathrm{BET}}$ was computed assuming that primary particles are spherical. The density of $\mathrm{Y}_{2} \mathrm{~W}_{3} \mathrm{O}_{12}$ in the hydrated form was that of the monoclinic cell (4.976 $\mathrm{gcm}^{-3}$, see Appendix A). 
Table 4.2- $S_{B E T}, d_{B E T}$, pore volume, pore size, and $d_{50}$ of $Y_{2} W_{3} O_{12}$ powders [84].

\begin{tabular}{cclccc}
\hline Sample & $\mathrm{S}_{\mathrm{BET}}\left(\mathrm{m}^{2} \mathrm{~g}^{-1}\right)$ & $\mathrm{d}_{\mathrm{BET}}(\mu \mathrm{m})$ & $\begin{array}{c}\text { Pore volume } \\
\left(\mathrm{cm}^{3} \mathrm{~g}^{-1}\right)\end{array}$ & $\begin{array}{c}\text { Pore size } \\
(\AA)\end{array}$ & $\mathrm{d}_{50}(\mu \mathrm{m})$ \\
\hline $\mathrm{Y}_{2} \mathrm{~W}_{3} \mathrm{O}_{12}-\mathrm{A}$ & 7.67 & 0.16 & 0.014 & 74.60 & 0.60 \\
$\mathrm{Y}_{2} \mathrm{~W}_{3} \mathrm{O}_{12}-\mathrm{B}$ & 6.97 & 0.17 & 0.012 & 69.26 & 0.70 \\
\hline
\end{tabular}

The $\mathrm{d}_{50}$ values of both $\mathrm{Y}_{2} \mathrm{~W}_{3} \mathrm{O}_{12}$ powders are comparable with the average particle sizes of $\mathrm{Sc}_{2} \mathrm{~W}_{3} \mathrm{O}_{12}$ and $\mathrm{Al}_{2} \mathrm{~W}_{3} \mathrm{O}_{12}$ powders measured by DLS and obtained from a particle size distribution in number, which were reported by Higgins et al. [18] as being 0.71 and $0.62 \mu \mathrm{m}$, respectively. These submicronic powders were prepared by a sophisticated combustion synthesis from nitrate salts of metals and ammonium metatungstate that reacted at $550{ }^{\circ} \mathrm{C}$ using urea as fuel and the corresponding precursors were thermally treated at $800{ }^{\circ} \mathrm{C}$ for $1 \mathrm{~h}$ [18]. BET surface areas of the as-synthesized $\mathrm{Y}_{2} \mathrm{~W}_{3} \mathrm{O}_{12}$ powders were higher than those of $\mathrm{Sc}_{2} \mathrm{~W}_{3} \mathrm{O}_{12}$ and $\mathrm{Al}_{2} \mathrm{~W}_{3} \mathrm{O}_{12}, 3.20$ and $0.17 \mathrm{~m}^{2} \mathrm{~g}^{-1}$, respectively. To the best of our knowledge, there are no additional reports in the literature concerning to the particle size distribution of $\mathrm{A}_{2} \mathrm{M}_{3} \mathrm{O}_{12}$ family members measured by representative techniques such as DLS or laser diffraction.

The $\mathrm{d}_{50}$ values of the two as-prepared $\mathrm{Y}_{2} \mathrm{~W}_{3} \mathrm{O}_{12}$ powders are similar, as well as $\mathrm{d}_{\mathrm{BET}}$ and pore volumes and sizes, the parameters that demonstrate that primary particles of agglomerates are essentially equivalent. This might suggest that the proposed co-precipitation methods do not have a strong influence on the agglomeration degree, even when a theoretically more efficient modified reverse strike co-precipitation was applied. In fact, in a typical reverse strike coprecipitation process an acid aqueous solution of metal salts is dropped into a large amount of a precipitant agent $\left(\mathrm{NH}_{4} \mathrm{OH}, \mathrm{NaOH}\right.$ or $\left.\mathrm{NH}_{4} \mathrm{HCO}_{3}\right)$ and the $\mathrm{pH}$ of the precipitant agent drops gradually as co-precipitation proceeds [25] or it is kept constant by the addition of precipitant agent [26]. Based on the last approach, controlling the $\mathrm{pH}$ is considered one of the most important factors during coprecipitation to assure that a high supersaturation level is held constant during the whole process, which in turn prevents particle size heterogeneity of precipitates that could result from $\mathrm{pH}$ fluctuations.

Therefore, the two co-precipitation methods applied in this work lead to an equivalent particle size distribution. Likely, the calcination stage is even more detrimental factor for the final agglomeration state of the $\mathrm{Y}_{2} \mathrm{~W}_{3} \mathrm{O}_{12}$ powders. The 
formation of submicronic hard agglomerates, consisted of necked primary particles indicating onset of sintering, was confirmed by FEG-SEM analysis. The size of the submicronic agglomerates of both samples was similar and is in accordance to $\mathrm{d}_{50}$ values obtained by laser diffraction (see Figure 4.8).
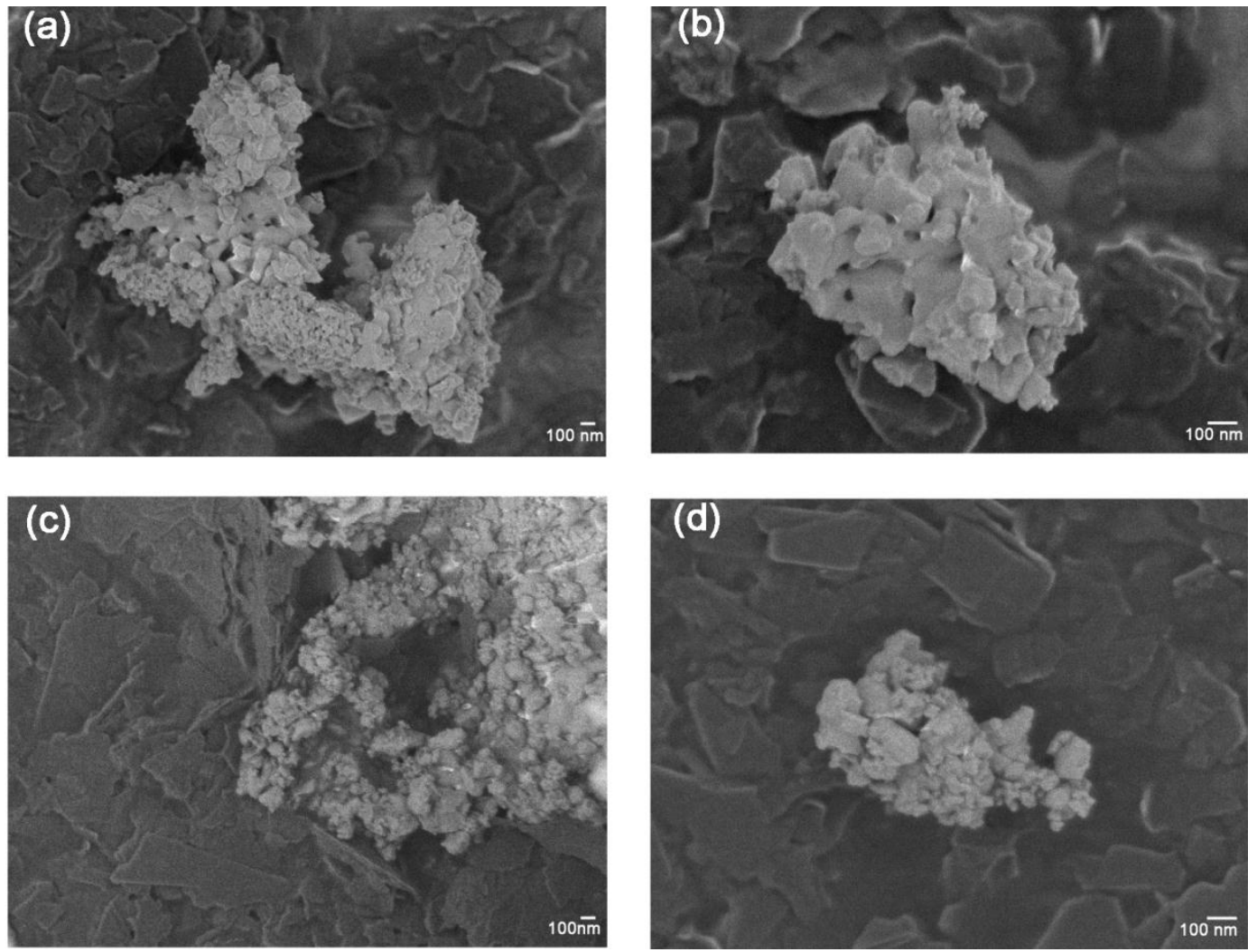

Figure 4.8- FEG-SEM images of the calcined (a-b) $\mathrm{Y}_{2} \mathrm{~W}_{3} \mathrm{O}_{12}-\mathrm{A}$ and (c-d) $\mathrm{Y}_{2} \mathrm{~W}_{3} \mathrm{O}_{12}$-B powders [84].

\section{4.}

\section{Conclusions}

$\mathrm{Y}_{2} \mathrm{~W}_{3} \mathrm{O}_{12}$ submicronic powders in the range of 0.60 to $0.70 \mu \mathrm{m}$ were synthesized through co-precipitation by mixing reactants and modified reverse strike co-precipitation. Both co-precipitation methods presented similar particle sizes and agglomeration degrees. The formation of oxyhydroxynitrate precursors can reduce the degree of agglomeration compared to hydroxyl ones. However, calcination process causes the formation of necks resulting in hard agglomerates. At room temperature hydrated $\mathrm{Y}_{2} \mathrm{~W}_{3} \mathrm{O}_{12}$ is predominantly monoclinic and the phase transition from monoclinic to orthorhombic form, accompanied by water release, was also detected by dilatometry at around $100{ }^{\circ} \mathrm{C}$. 
5

\section{Effects of the synthesis conditions on the agglomeration state of $\mathrm{Al}_{2} \mathrm{~W}_{3} \mathrm{O}_{12}$ submicronic powders prepared by co- precipitation method}

\section{1. Background}

One of the most studied phases among $\mathrm{A}_{2} \mathrm{M}_{3} \mathrm{O}_{12}$ family members, exhibiting low positive thermal expansion feature, is $\mathrm{Al}_{2} \mathrm{~W}_{3} \mathrm{O}_{12}$ due to its simple chemistry, low cost and potential applications not only in the field of composite materials but also as an engineering ceramic. Recently, the Hasselman thermal shock resistance figure of merit of $\mathrm{Al}_{2} \mathrm{~W}_{3} \mathrm{O}_{12}$ compacts for severe heating conditions (R) has been reported by Prisco et al. [19], as being $120 \mathrm{~K}$, which is the same value as the one reported for sapphire, the archetypal material for thermalshock-resistant infrared windows, demonstrating that $\mathrm{Al}_{2} \mathrm{~W}_{3} \mathrm{O}_{12}$ and related phases could be promissory in this field. However, this $\mathrm{R}$ value would be higher if the module of rupture $(\sigma)$ of $\mathrm{Al}_{2} \mathrm{~W}_{3} \mathrm{O}_{12}$ monolithic ceramics would not have been considerably low $(\sigma<10 \mathrm{MPa})$. These authors pointed out that the highly agglomerated state of $\mathrm{Al}_{2} \mathrm{~W}_{3} \mathrm{O}_{12}$ nanopowder used in that study and, synthesized by total evaporation route, had a strong influence on the final microstructure (coarse-grain and inhomogeneous) of $\mathrm{Al}_{2} \mathrm{~W}_{3} \mathrm{O}_{12}$ bulk specimens, the main cause for their low mechanical strength [19]. Hence, further development of synthesis routes devoted to prepare $\mathrm{Al}_{2} \mathrm{~W}_{3} \mathrm{O}_{12}$ nano or submicronic powders with low agglomeration degree is a key factor to improve the microstructure of bulk sintered samples, and in turn, $\sigma$ and $\mathrm{R}$ values.

$\mathrm{Al}_{2} \mathrm{~W}_{3} \mathrm{O}_{12}$ has been synthesized by solid state reaction [6], co-precipitation [26, 73], sol-gel method [83], total evaporation route [19] and combustion synthesis using urea or carbohydrazide as a fuel [18]. The co-precipitation method allows obtaining generally more nanometric primary particles [83]. Even though, due to the high specific surface area of co-precipitated nanoparticles and the 
calcination stage, necessary for crystallization of the amorphous precursors, nanoparticles in crystalline powder tend to form hard agglomerates [84], which could restrain their use.

The main tungsten sources for the preparation of $\mathrm{Al}_{2} \mathrm{~W}_{3} \mathrm{O}_{12}$ are sodium tungstate $\left(\mathrm{Na}_{2} \mathrm{WO}_{4} \cdot 2 \mathrm{H}_{2} \mathrm{O}\right) \quad[21,83]$ and ammonium metatungstate $\left(\left(\mathrm{NH}_{4}\right)_{6} \mathrm{~W}_{12} \mathrm{O}_{39} \cdot \mathrm{XH}_{2} \mathrm{O}\right)[18,19]$. The former has been widely used for the coprecipitation of $\mathrm{Al}_{2} \mathrm{~W}_{3} \mathrm{O}_{12}$, as described by Zhecheva et al. [21]. In that synthesis, $0.1 \mathrm{M}$ aqueous solutions of $\mathrm{Al}\left(\mathrm{NO}_{3}\right)_{3} \cdot 9 \mathrm{H}_{2} \mathrm{O}$ and $\mathrm{Na}_{2} \mathrm{WO}_{4} \cdot 2 \mathrm{H}_{2} \mathrm{O}$ are mixed together and the co-precipitation occurs because the $\mathrm{pH}$ of the sodium tungstate solution is high enough to achieve the supersaturation state and induces the coprecipitation of precursor without the addition of a precipitant agent. This method is the so-called "co-precipitation by mixing reactants" and occurs at a constant $\mathrm{pH}$. An amorphous hydroxide precursor of $\mathrm{Al}_{2} \mathrm{~W}_{3} \mathrm{O}_{12}$ can be formed in a wide $\mathrm{pH}$ range from 4 to 6 [22]. However, no studies about the influence of synthesis $\mathrm{pH}$ on the agglomeration state of $\mathrm{Al}_{2} \mathrm{~W}_{3} \mathrm{O}_{12}$ powders have been reported yet.

On the other hand, severe agglomeration of gelatinous hydroxide amorphous precursors is commonly observed during drying and agglomerates will inevitably persist in calcined powders, as aforementioned in section 2.5.1. Therefore, the use of other types of precipitant agents to avoid the formation of hydroxide precursors has triggered a lot of research, especially for the synthesis of yttrium aluminum garnet (YAG) precursors [85]. Based on this approach, $\left(\mathrm{NH}_{4}\right)_{6} \mathrm{~W}_{12} \mathrm{O}_{39} \cdot \mathrm{xH}_{2} \mathrm{O}$ could be used as a tungsten source, because its aqueous solution possesses a much lower $\mathrm{pH}$ than that of sodium tungstate solution. Accordingly, it does not induce the co-precipitation when mixed with aluminum nitrate solution. Therefore, the addition of a more basic solution (precipitant agent) into the acidic solution formed after mixing aluminum nitrate and ammonium metatungstate is necessary to produce the precipitate. This is the sodenoted "normal strike co-precipitation" [24]. Hence, under these conditions ammonium hydrogen carbonate $\left(\mathrm{AHC}: \mathrm{NH}_{4} \mathrm{HCO}_{3}\right)$ can fulfill the role of the precipitant agent. Indeed, the use of $\mathrm{AHC}$ as a precipitant agent to prepare a carbonate-based precursor has not been reported in the literature for the synthesis of $\mathrm{A}_{2} \mathrm{M}_{3} \mathrm{O}_{12}$ family members by co-precipitation method.

Another important factor that strongly influences on agglomeration of powders is the drying method of the precursor. When conventional oven drying is 
adopted, with the continuous solvent evaporation, capillarity attraction can occur among precursor nanoparticles, which brings them together and it is the driving force that leads to serious agglomeration [42]. Other drying methods of the precursor such as freeze drying, vacuum drying and microwave drying can reduce the agglomeration of the nanoparticles and they have not been applied yet in the synthesis of $\mathrm{A}_{2} \mathrm{M}_{3} \mathrm{O}_{12}$ family.

There is a lack of information about the agglomeration state of $\mathrm{Al}_{2} \mathrm{~W}_{3} \mathrm{O}_{12}$ and similar powders, measured through representative techniques, such as laser diffraction or dynamic light scattering (DLS). Ony the work developed by Higgins et al.[18] presents the particle size distribution of $\mathrm{Al}_{2} \mathrm{~W}_{3} \mathrm{O}_{12}$ submicronic powders prepared by combustion synthesis measured by DLS and compares the results with those obtained by FEG-SEM [18].

In this context, the aim of this study is to synthesize $\mathrm{Al}_{2} \mathrm{~W}_{3} \mathrm{O}_{12}$ powders by two co-precipitation methods using two tungsten sources (sodium tungstate and ammonium metatungstate) and two different synthesis $\mathrm{pH}$ (4.2 and 6.0), generating four different powders (see Figure 5.1), in order to assess the effect of these variables on the agglomeration state of $\mathrm{Al}_{2} \mathrm{~W}_{3} \mathrm{O}_{12}$ powders.

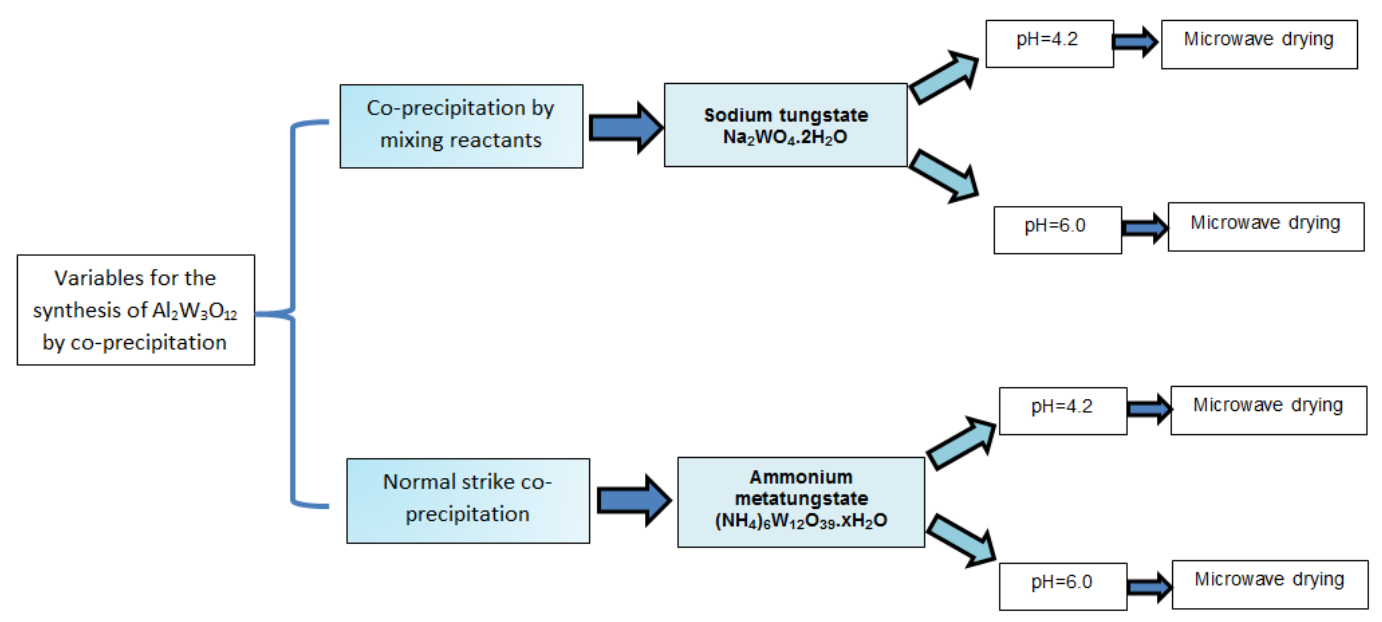

Figure 5.1- Scheme of the studied variables in the synthesis of $\mathrm{Al}_{2} \mathrm{~W}_{3} \mathrm{O}_{12}$ by coprecipitation. 


\section{2.}

\section{Materials and methods}

\subsection{1.}

\section{Co-precipitation by mixing reactants}

The co-precipitation was conducted by mixing $0.1 \mathrm{M}$ aqueous solutions of $\mathrm{Al}\left(\mathrm{NO}_{3}\right)_{3} \cdot 9 \mathrm{H}_{2} \mathrm{O}$ (Isofar, 99\%) and $\mathrm{Na}_{2} \mathrm{WO}_{4} \cdot 2 \mathrm{H}_{2} \mathrm{O}$ (Sigma Aldrich, 99\%), as depicted in Figure 5.2. A milky gelatinous amorphous precipitate was immediately formed $(\mathrm{pH} \sim 4.2)$ and this suspension was stirred for $10 \mathrm{~min}$. The precipitate was recovered by centrifugation and washed thoroughly three times with anhydrous ethanol (Vetec, 99.9\%). The co-precipitate gel was microwave dried (MW) using a conventional domestic microwave oven during $3 \mathrm{~min}$. Finally, the amorphous precursors were calcined under the conditions described in section 5.3.3.

To prepare $\mathrm{Al}_{2} \mathrm{~W}_{3} \mathrm{O}_{12}$ precursor synthesized up to $\mathrm{pH}=6.0,1 \mathrm{M} \mathrm{NaOH}$ aqueous solution was dropped into the milky gelatinous precipitate, previously obtained at $\mathrm{pH} 4.2$, to adjust the $\mathrm{pH}$ to the desired value and the resulting suspension was stirred for $10 \mathrm{~min}$. The same procedures of recovering, washing, drying and calcination mentioned above were adopted in this case, as well.

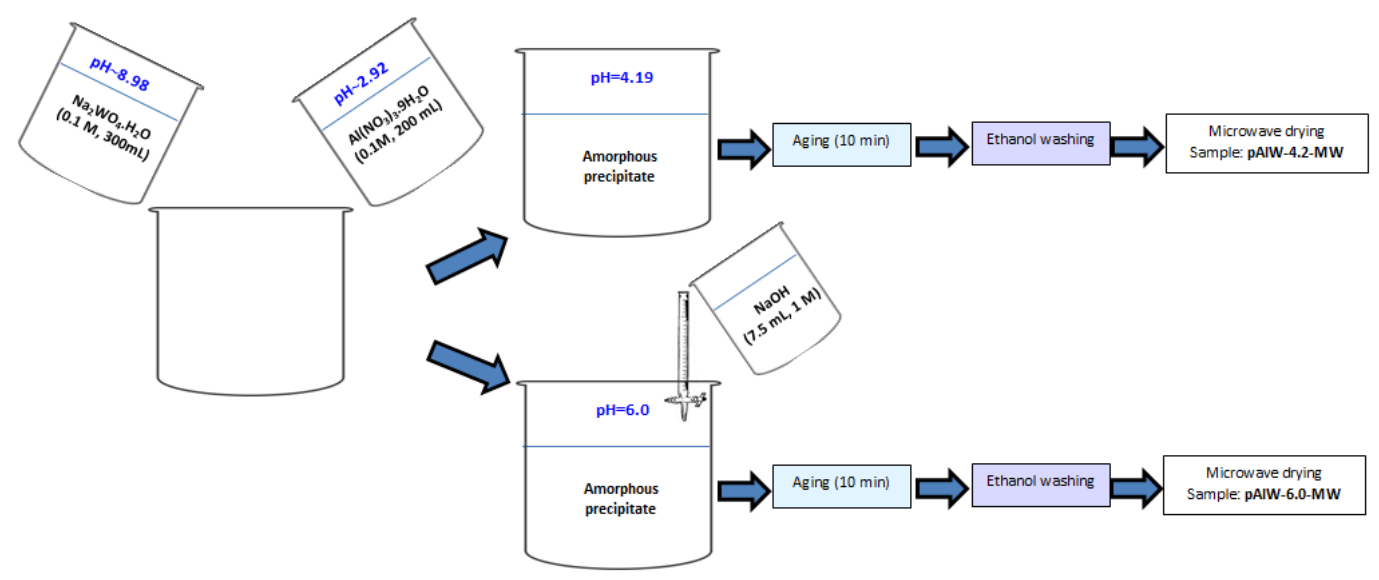

Figure 5.2- Scheme of the co-precipitation of $\mathrm{Al}_{2} \mathrm{~W}_{3} \mathrm{O}_{12}$ amorphous precursors by mixing reactants, using $\mathrm{Na}_{2} \mathrm{WO}_{4} \cdot 2 \mathrm{H}_{2} \mathrm{O}$ as tungsten source. 


\subsection{2.}

\section{Normal strike co-precipitation}

This co-precipitation was carried out using $0.1 \mathrm{M}$ aqueous solutions of $\mathrm{Al}\left(\mathrm{NO}_{3}\right)_{3} \cdot 9 \mathrm{H}_{2} \mathrm{O}$ (Isofar, 99\%) and $\left(\mathrm{NH}_{4}\right)_{6} \mathrm{~W}_{12} \mathrm{O}_{39} \cdot \mathrm{xH}_{2} \mathrm{O}$ (Alfa Aesar, 99\%). These solutions were mixed together and no precipitate formed. Next, 1.5 M AHC aqueous solution was added into the system at a dripping speed of 2-3 $\mathrm{mLmin}^{-1}$. The titration was suspended when $\mathrm{pH}$ values of 4.2 and 6.0 were reached, respectively (see Figure 5.3). Afterwards, the milky suspensions were stirred for $10 \mathrm{~min}$. The conditions of recovering, washing and drying of precursors were identical to those aforesaid in section 5.2.1, while the calcination conditions are presented in section 5.3.3.

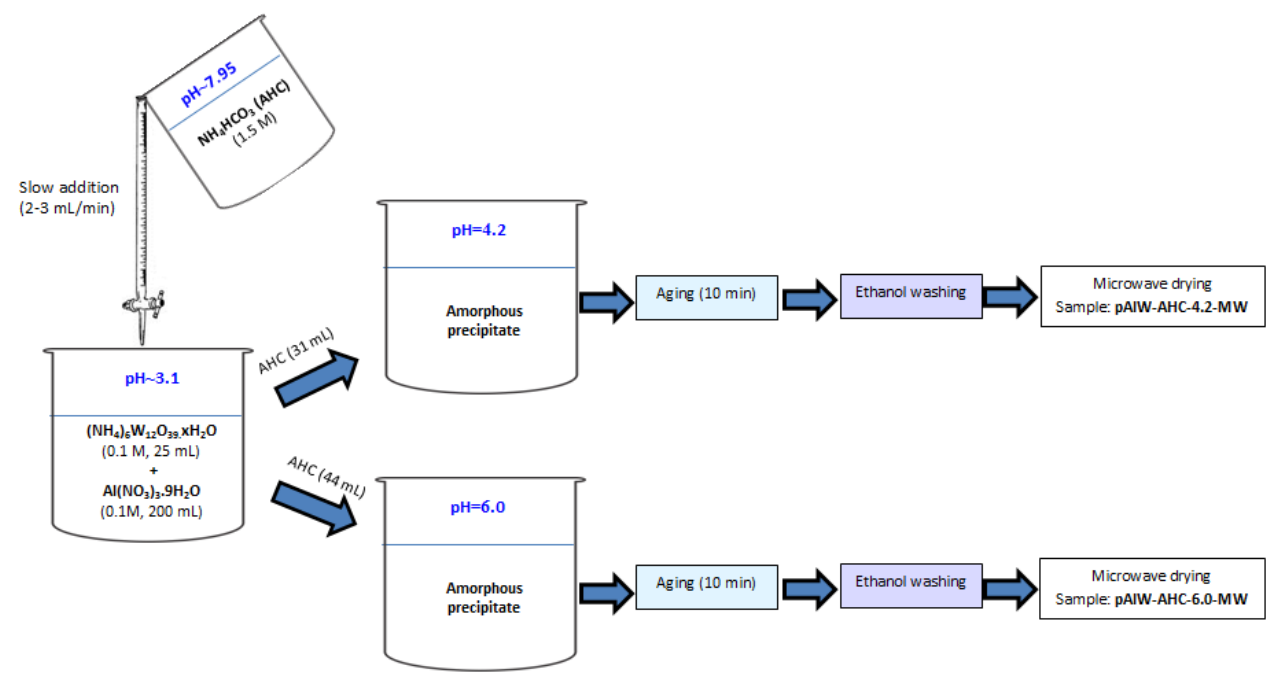

Figure 5.3- Scheme of normal strike co-precipitation of $\mathrm{Al}_{2} \mathrm{~W}_{3} \mathrm{O}_{12}$ with $\left(\mathrm{NH}_{4}\right)_{6} \mathrm{~W}_{12} \mathrm{O}_{39} \cdot \mathrm{xH}_{2} \mathrm{O}$ as tungsten source and $\mathrm{AHC}$ as precipitant agent.

The nomenclature of the as-synthesized $\mathrm{Al}_{2} \mathrm{~W}_{3} \mathrm{O}_{12}$ precursor samples is shown in Table 5.1. 
Table 5.1- Nomenclature of $\mathrm{Al}_{2} \mathrm{~W}_{3} \mathrm{O}_{12}$ precursors.

\begin{tabular}{|c|c|c|c|c|c|}
\hline Method & Tungsten source & $\begin{array}{l}\text { Final } \\
\mathrm{pH}\end{array}$ & $\begin{array}{l}\text { Aging } \\
\text { (min) }\end{array}$ & Drying method & Samples \\
\hline Co-precipitation by & \multirow{2}{*}{$\mathrm{Na}_{2} \mathrm{WO}_{4} \cdot 2 \mathrm{H}_{2} \mathrm{O}$} & 4.2 & 10 & Microwave & pAlW-4.2-MW \\
\hline mixing reactants & & 6.0 & 10 & Microwave & pAlW-6.0-MW \\
\hline Normal strike & \multirow{2}{*}{$\left(\mathrm{NH}_{4}\right)_{6} \mathrm{~W}_{12} \mathrm{O}_{39} \cdot \mathrm{xH}_{2} \mathrm{O}$} & 4.2 & 10 & Microwave & pAlW-AHC-4.2-MW \\
\hline co-precipitation & & 6.0 & 10 & Microwave & pAlW-AHC-6.0-MW \\
\hline
\end{tabular}

\subsection{3.}

\section{Characterization of $\mathrm{Al}_{2} \mathrm{~W}_{3} \mathrm{O}_{12}$ precursors and powders}

DSC analyses of the precursors were carried out following the procedures and same equipments described in section 4.2.3, as well as, CHN elemental analyses. Zeta potential measurements of the precipitated precursor particles (amorphous) were conducted in a Zeta-Meter +4.0 (Zeta Meter Inc., USA). During a typical synthesis, an aliquot of the precipitate suspension was collected at different $\mathrm{pH}$ values and placed within the acrylic cell. An aqueous solution of $\operatorname{KBr}\left(1 \times 10^{-4} \mathrm{M}\right)$ was used as electrolyte.

XRPD analyses of $\mathrm{Al}_{2} \mathrm{~W}_{3} \mathrm{O}_{12}$ crystalline powders, the determination of specific surface area by BET nitrogen adsorption, the measurement of particle size distribution in number of the calcined powders by laser diffraction and the study of the morphology of crystalline powders by FEG-SEM, were performed using the same equipments and procedures also presented in section 4.2.3.

\section{3.}

Results and discussions

\subsection{1. Co-precipitation of $\mathrm{Al}_{2} \mathrm{~W}_{3} \mathrm{O}_{12}$ amorphous precursors using two tungsten sources}

Different tungsten sources give rise to different co-precipitation methods. In the case of co-precipitation by mixing reactants, the high $\mathrm{pH}$ value of $\mathrm{Na}_{2} \mathrm{WO}_{4}$ aqueous solution ( 9) promotes the instantaneous co-precipitation of a milky gelatinous amorphous precursor when it is mixed with $\mathrm{Al}\left(\mathrm{NO}_{3}\right)_{3}$ aqueous solution (see Figure 5.2).

At this point, it is worth noting that the co-precipitation of $\mathrm{Al}_{2} \mathrm{~W}_{3} \mathrm{O}_{12}$ amorphous precursors occurs at a $\mathrm{pH}$ akin to that required for the precipitation of 
amorphous aluminum hydroxide $\left(\mathrm{Al}(\mathrm{OH})_{3}\right)$, between 3.5 and 4.5 [86,87]. The $\mathrm{pH}=4.2$ for the co-precipitation of $\mathrm{Al}_{2} \mathrm{~W}_{3} \mathrm{O}_{12}$ amorphous precursor by mixing reactants is within this $\mathrm{pH}$ range. This useful empirical approach to estimate the $\mathrm{pH}$ of co-precipitation of some metal tungstates from the corresponding metal hydroxide was also valid for the synthesis of $\mathrm{Y}_{2} \mathrm{~W}_{3} \mathrm{O}_{12}$ submicronic powders, where the co-precipitation $\mathrm{pH}$ of an oxy-hydroxynitrate amorphous precursor resembles the $\mathrm{pH}$ value needed for the precipitation of respective yttrium hydroxynitrate (see section 4.3.1) [84].

Koseva et al. [22] stated that an amorphous precursor of $\mathrm{Al}_{2} \mathrm{~W}_{3} \mathrm{O}_{12}$ can be obtained in a broad range of $\mathrm{pH}$ (4.0 to 6.0) without any adjustment of $\mathrm{pH}$, using the same co-precipitation method, identical reactant aqueous solutions and concentrations. However, the results obtained in the present work demonstrate that the co-precipitation takes place at $\mathrm{pH}=4.2$ and a higher $\mathrm{pH}$ value could be merely attained through addition of a base, as reported by Jardim et al. [4], who used a $\mathrm{NH}_{4} \mathrm{OH}$ solution to adjust the $\mathrm{pH}$ up to 6.0, under the same co-precipitation conditions.

When $\left(\mathrm{NH}_{4}\right)_{6} \mathrm{~W}_{12} \mathrm{O}_{39}$ is the tungsten source, the addition of a base is mandatory to induce the co-precipitation of amorphous precursor via normal strike method. Thus, when AHC is used as precipitant agent the co-precipitation begins at $\mathrm{pH}=3.45$ and the $\mathrm{pH}$ remains almost constant during this process (from 3.77 to 4.25 ) as can be seen in Figure 5.4.a, following the same $\mathrm{pH}$ range expected for precipitation of pseudoboehmite $(\mathrm{AlOOH})$ [88,89], which is the main compound that precipitates when $1.5 \mathrm{M}$ AHC solution is dropped into $\mathrm{Al}\left(\mathrm{NO}_{3}\right)_{3}$ aqueous solution. The precipitation ends at $\mathrm{pH}=4.25$ and further increase in $\mathrm{pH}$ is due to the excess of precipitant agent. At $\mathrm{pH}=6.0$ the milky precursor suspension turned less viscous. A second plateau was observed by further addition of AHC solution in the $\mathrm{pH}$ range between 7.4 and 7.8 (see Figure 5.4.b), where the precipitate suspension was even less milky and viscous. The mass of dried precursor obtained at terminal $\mathrm{pH}=7.8$ was only $\sim 40 \%$ of the mass of precursor synthesized at $\mathrm{pH}=4.2$. Therefore, $\mathrm{pH}$ values higher than 7.0 are not suitable for the synthesis of $\mathrm{Al}_{2} \mathrm{~W}_{3} \mathrm{O}_{12}$ precursor because of the risk of redissolution of the precursor. As a matter of fact, the redissolution of aluminum hydroxide precipitated species in the $\mathrm{pH}$ range of 7.2 to 7.8 has been reported in the case of 
widely studied YAG precursors prepared by normal-strike co-precipitation using an AHC solution [88]. For this reason, this synthesis was conducted up to a maximum $\mathrm{pH}=6.0$.

(a)

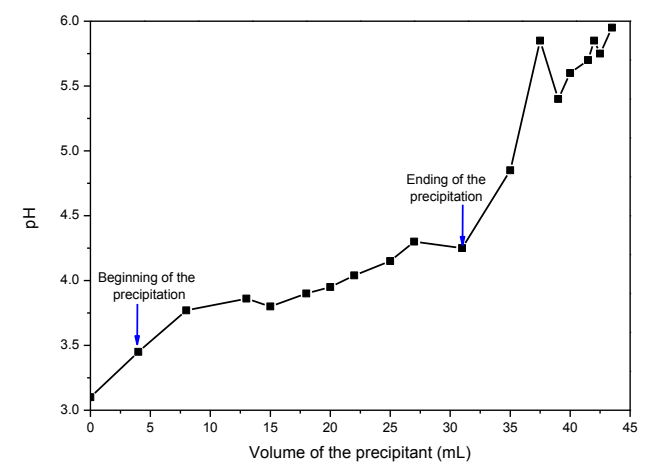

(b)

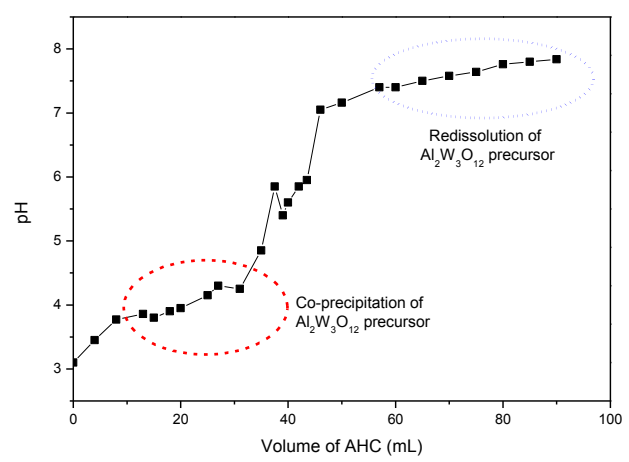

Figure 5.4- Titration curve of the solution formed after mixing aqueous solutions $0.1 \mathrm{M}$ of $\mathrm{Al}\left(\mathrm{NO}_{3}\right)_{3} \cdot 9 \mathrm{H}_{2} \mathrm{O}$ and $\left(\mathrm{NH}_{4}\right)_{6} \mathrm{~W}_{12} \mathrm{O}_{39} \cdot \mathrm{xH}_{2} \mathrm{O}$ up to (a) $\mathrm{pH}=6.0$ and (b) $\mathrm{pH}$ near 8.0. The precipitant was $1.5 \mathrm{M} \mathrm{AHC}$ solution (dripping speed: $2-3 \mathrm{mLmin}^{-1}$ ).

\subsection{2.}

\section{Composition of the amorphous precursors}

In respect to the chemical composition of $\mathrm{Al}_{2} \mathrm{~W}_{3} \mathrm{O}_{12}$ amorphous precursors prepared through co-precipitation by mixing reactants at $\mathrm{pH}=4.2$ and $\mathrm{pH}=6.0$, these precursors are of hydroxide-type [21] since $\mathrm{OH}^{-}$and tungstate species are the only anions within the reaction medium that can be part of the precursor, while $\mathrm{NO}_{3}{ }^{-}$ions are not involved in the co-precipitation process as demonstrated by Zhecheva et. al [21].

The composition of $\mathrm{Al}_{2} \mathrm{~W}_{3} \mathrm{O}_{12}$ amorphous precursors synthesized via normal-strike co-precipitation is the result of competition between hydroxyl and carbonate species generated by the dissociation of AHC in water (see Equations 5.1 to 5.4), and the subsequent chemical reactions with aluminum and tungstate species.

$$
\begin{aligned}
& \mathrm{NH}_{4} \mathrm{HCO}_{3}+\mathrm{H}_{2} \mathrm{O} \Leftrightarrow \mathrm{NH}_{4} \mathrm{OH}+\mathrm{H}_{2} \mathrm{CO}_{3} \\
& \mathrm{NH}_{4} \mathrm{OH} \Leftrightarrow \mathrm{NH}_{4}^{+}+\mathrm{OH}^{-} \\
& \mathrm{H}_{2} \mathrm{CO}_{3} \Leftrightarrow \mathrm{H}^{+}+\mathrm{HCO}_{3}^{-}
\end{aligned}
$$




$$
\mathrm{HCO}_{3}^{-} \Leftrightarrow \mathrm{H}^{+}+\mathrm{CO}_{3}^{=}
$$

Considering merely the titration of $\mathrm{Al}\left(\mathrm{NO}_{3}\right)_{3}$ with $1.5 \mathrm{M}$ AHC solution by normal-strike method, the precipitation of $\mathrm{AlOOH}$ occurs under these conditions at a pH plateau from 3.5 to 4.5 [88], as stated before. During aging, carbonate ions $\left(\mathrm{CO}_{3}\right)^{2-}$ exchange with $\mathrm{AlOOH}$ precursor and the final product varies from $\mathrm{AlOOH}$ to ammonium dawsonite $\left(\mathrm{NH}_{4} \mathrm{Al}(\mathrm{OH})_{2} \mathrm{CO}_{3} \cdot \mathrm{xH}_{2} \mathrm{O}\right)$, including $\mathrm{AlOHCO}_{3}$, depending on the amount of AHC in the reaction medium $[88,89]$. Thus, a suitable aging is required for the conversion of the hydroxide precursor into a crystalline carbonate compound. However, during aging not only the formation of a carbonate precursor is favored, but also particle growth of precipitate by Ostwald ripening [37] and/or agglomeration of particles under van der Waals attractive forces, depending on the $\mathrm{pH}$ of the reaction medium [85][90]. Actually, Ostwald ripening is caused by the higher solubility of small particles due to their high surface curvature compared to larger ones. Accordingly, small particles dissolve and the material is reprecipitated onto large particles [37].

The $\mathrm{pH}$ of the aqueous suspension of pAlW-AHC-6 was monitored during $1 \mathrm{~h}$ of aging and it increases up to 6.4, as shown in Figure 5.5. An aging time of 10 min was chosen to keep the $\mathrm{pH}$ of the precursor suspension almost constant and to avoid the tendency of further growth of the precursor particles even when the formation of a carbonate precursor would be constrained by a short aging time.

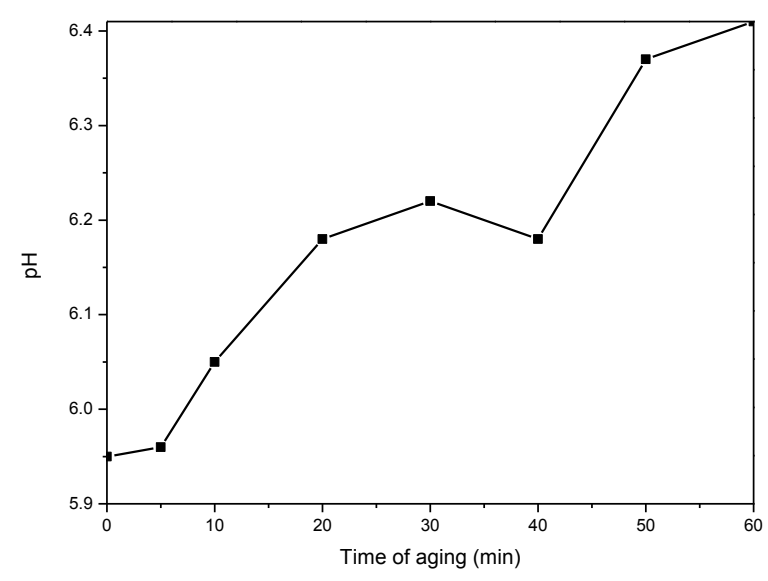

Figure 5.5- $\mathrm{pH}$ of the aqueous suspension of pAIW-AHC-6 as a function of aging time. 
An approximate chemical composition of $\mathrm{Al}_{2} \mathrm{~W}_{3} \mathrm{O}_{12}$ amorphous precursors prepared by normal-strike method can be estimated based on CHN results presented in Table 5.2. After thoroughly washing of these precursors with distilled water no traces of nitrogen (from $\mathrm{NH}_{4}^{+}$and/or $\mathrm{NO}_{3}^{-}$groups) were identified. Therefore, amonium dawsonite-based precursors were not precipitated. However, the carbon content of these precursors suggests that some $\mathrm{OH}^{-}$groups were indeed exchanged with $\mathrm{CO}_{3}{ }^{2-}$ or $\mathrm{HCO}_{3}{ }^{-}$groups to produce hydroxycarbonate-based precursors.

Table 5.2. $\mathrm{CHN}$ results of $\mathrm{Al}_{2} \mathrm{~W}_{3} \mathrm{O}_{12}$ precursors synthesized by normal strike coprecipitation.

\begin{tabular}{clll}
\hline Samples & $\begin{array}{c}\text { Nitrogen } \\
(\text { mass \%) }\end{array}$ & $\begin{array}{l}\text { Carbon } \\
(\text { mass \%) }\end{array}$ & $\begin{array}{l}\text { Hydrogen } \\
(\text { mass \%) }\end{array}$ \\
\hline pAlW-AHC-4-MW & - & 0.7 & 2.2 \\
pAlW-AHC-6-MW & - & 1.0 & 4.3 \\
\hline
\end{tabular}

Due to the complex reactions involved during both co-precipitation processes, it is possible that aluminum oxyhydroxide species could be also part of the precursors. However, the terms "hydroxide" or "hydroxycarbonate-based precursors" defined herein are intended to include also these species.

\subsection{3.}

\section{Crystallization temperature of as-synthesized precursors}

Precursors prepared through co-precipitation by mixing reactants display a crystallization temperature lower than those obtained by normal strike method, as can be seen in Figure B. 1 in Appendix B, where DSC curves of $\mathrm{Al}_{2} \mathrm{~W}_{3} \mathrm{O}_{12}$ microwave dried precursors are presented. This difference in the crystallization temperature can be attributed to the chemical composition of precursors synthesized by two different co-precipitation methods. Hence, hydroxycarbonatebased precursors (pAlW-AHC-4.2 and pAlW-AHC-6.0) should be calcined at temperatures higher than those required for hydroxide ones (pAlW-4.2 and pAlW6.0), see Table 5.3. 
Table 5.3- Crystallization and calcination temperatures of $\mathrm{Al}_{2} \mathrm{~W}_{3} \mathrm{O}_{12}$ as-synthesized precursors.

\begin{tabular}{lcc}
\hline \multicolumn{1}{c}{ Precursor samples } & $\begin{array}{c}\text { Crystallization } \\
\text { temperature }\left({ }^{\circ} \mathrm{C}\right)\end{array}$ & $\begin{array}{c}\text { Calcination } \\
\text { temperature }\left({ }^{\circ} \mathrm{C}\right)\end{array}$ \\
\hline pAlW-4.2-MW & 592 & 630 \\
pAlW-6.0-MW & 560 & 630 \\
pAlW-AHC-4.2-MW & 622 & 750 \\
pAlW-AHC-6.0-MW & 710 & 750 \\
\hline
\end{tabular}

In order to avoid the influence of calcination temperature on the state of agglomeration among samples synthesized by the same method, two calcination temperatures were chosen: $630{ }^{\circ} \mathrm{C}$ for all the precursor samples obtained via $c o$ precipitation by mixing reactants and $750{ }^{\circ} \mathrm{C}$ for all precursors prepared by normal strike co-precipitation method (see Table 5.3). These calcination temperatures were chosen taking into account the highest crystallization temperature for each co-precipitation method $\left(592{ }^{\circ} \mathrm{C}\right.$ and $710{ }^{\circ} \mathrm{C}$ for precursors prepared via co-precipitation by mixing reactants and normal strike coprecipitation, respectively). Thus, the calcination temperature was $\sim 40{ }^{\circ} \mathrm{C}$ higher than the crystallization temperatures of those precursors to warrant the complete crystallization of all samples. Precursor samples were calcined during $30 \mathrm{~min}$ at a heating rate of $20{ }^{\circ} \mathrm{Cmin}^{-1}$.

XRPD pattern of AlW-4.2-MW sample is presented in Figure 5.6. Le Bail adjustment of calculated diffraction profile to experimental pattern indicated presence of the desired $\mathrm{Al}_{2} \mathrm{~W}_{3} \mathrm{O}_{12}$ orthorhombic phase (Pbcn space group), which was verified for all the samples synthesized by the two co-precipitation methods. XRPD for the rest of synthesized samples are not presented herein since $\mathrm{Al}_{2} \mathrm{~W}_{3} \mathrm{O}_{12}$ phase is the same. 


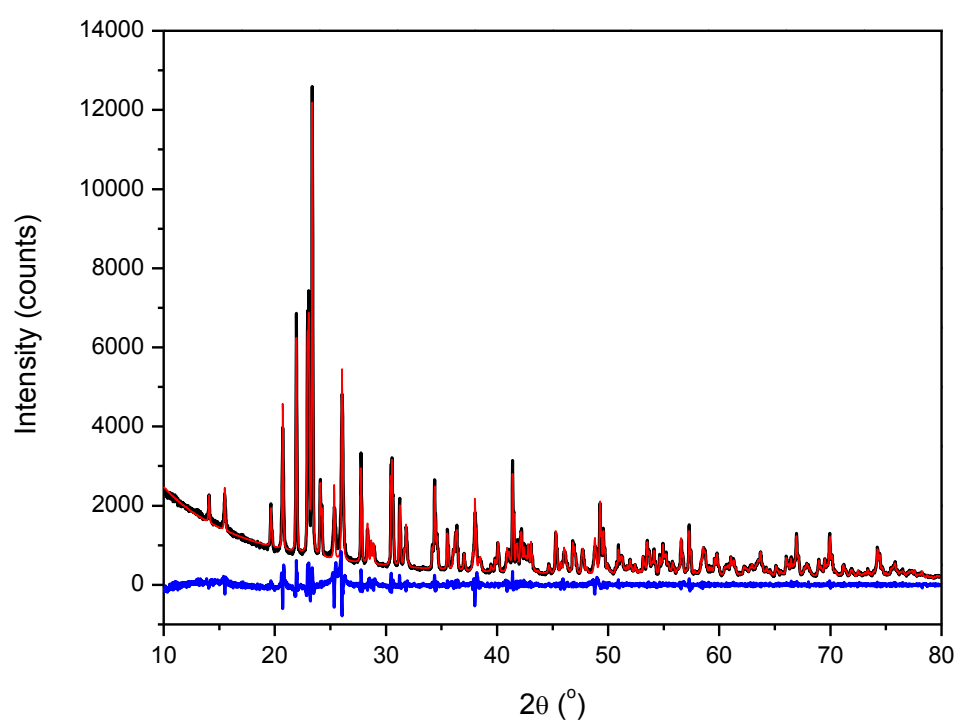

Figure 5.6- XRPD pattern of AIW-4.2-MW sample synthesized by co-precipitation by mixing reactants. The experimental pattern is black, the calculated pattern is red and the difference plot is blue.

\subsection{4.}

\section{Effect of synthesis pH on zeta potential of as-synthesized precursors}

The net surface charge of $\mathrm{Al}_{2} \mathrm{~W}_{3} \mathrm{O}_{12}$ amorphous precursors synthesized via co-precipitation by mixing reactants is slightly negative at $\mathrm{pH}=4.2$, as given by zeta potential curve presented at Figure 5.7.a. At $\mathrm{pH}=6.0$ the zeta potential was strongly negative, which indicates that precursor particles are more dispersed into the reaction medium and less agglomerated at this condition (see Figure 5.7.b). The negative sign in zeta potential could be the result of excess of $\mathrm{OH}^{-}$groups on the particle surfaces during the synthesis at $\mathrm{pH}=4.2$, where no precipitant agent was poured into the system. Thus, the excess of $\mathrm{OH}^{-}$in the reaction medium could interact with $\mathrm{OH}^{-}$surface groups of the precursor. Since a $0.1 \mathrm{M} \mathrm{NaOH}$ aqueous solution was added to the reaction medium to achieve a $\mathrm{pH}=6.0$, the $\mathrm{OH}^{-}$could increase the negative surface charge of precipitate particles even more, as illustrated in Figure 5.7.b. 
(a)

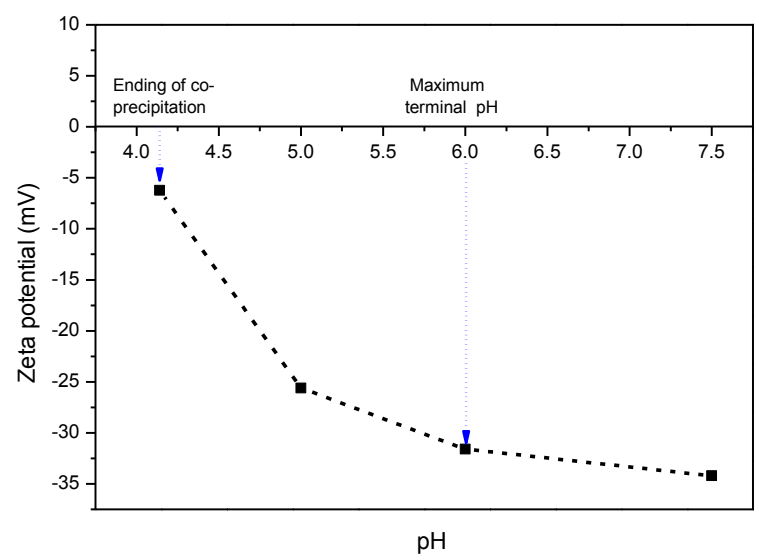

(b)
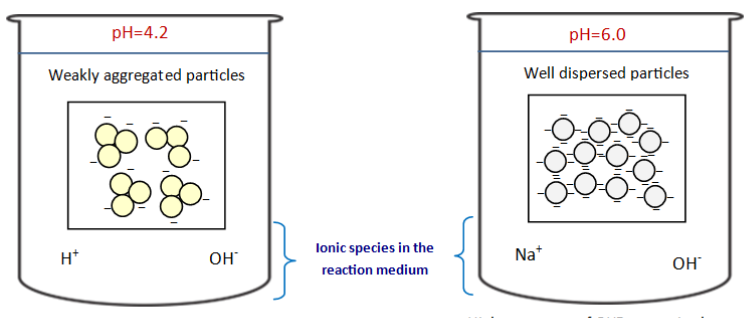

Higher amount of $\mathrm{OH}^{-}$groups in the reaction medium due to addition of $\mathrm{NaOH}$ solution

Figure 5.7- (a) Zeta potential of $\mathrm{Al}_{2} \mathrm{~W}_{3} \mathrm{O}_{12}$ precursor synthesized via co-precipitation by mixing reactants as a function of $\mathrm{pH}$ during titration with $1 \mathrm{M} \mathrm{NaOH}$ up to $\mathrm{pH} 8$ and (b) schematic representation of precursor particles in reaction medium at $\mathrm{pH}=4.2$ and $\mathrm{pH}=6.0$.

At $\mathrm{pH}=4.2$, the co-precipitation of $\mathrm{Al}_{2} \mathrm{~W}_{3} \mathrm{O}_{12}$ amorphous precursor via normal strike method is completed and the zeta potential of the freshlyprecipitated precursor particles, measured at the reaction medium conditions, is slightly positive (see Figure 5.8.a). However, the zeta potential of precursor particles at $\mathrm{pH}=6.0$ is strongly positive and the electrostatic repulsion among particles increases as depicted in Figure 5.8.b. Thus, precursor particles are more dispersed in the reaction medium at this $\mathrm{pH}$. 
(a)

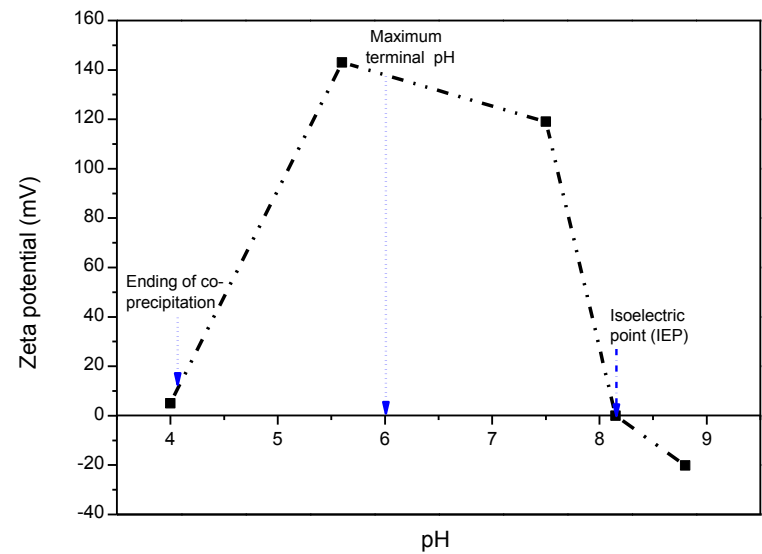

(b)

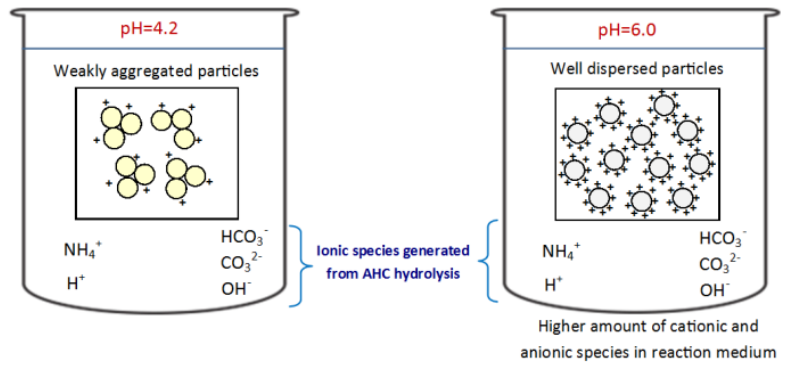

Figure 5.8- (a) Zeta potential of $\mathrm{Al}_{2} \mathrm{~W}_{3} \mathrm{O}_{12}$ precursor synthesized by normal-strike coprecipitation as a function of $\mathrm{pH}$ during titration with $1.5 \mathrm{M} \mathrm{AHC}$ solution up to $\mathrm{pH} 7.95$ (further increase in $\mathrm{pH}$ was attained through addition of $1 \mathrm{M} \mathrm{NaOH}$ solution) and (b) schematic representation of precursor particles in reaction medium at $\mathrm{pH}=4.2$ and $\mathrm{pH}=6.0$.

The increase on zeta potential of amorphous precursor at $\mathrm{pH}=6.0$ is not completely understood. The high zeta potential at $\mathrm{pH}=6.0$ is possibly a consequence of the excess of $\mathrm{NH}_{4}{ }^{+}$and $\mathrm{H}^{+}$groups generated from the dissociation of AHC precipitant agent (Equation (5.2) to Equation (5.4)) that could interact with $-\mathrm{OH}$ surface groups of the precursor.

The absorption of $\mathrm{NH}_{4}^{+}$groups on the surface of pAlW-AHC-4.2 and pAlW-AHC-6.0 was verified through CHN analyses of these precursors without washing (see Table B.1, Appendix B). Washing process removes $\mathrm{NH}_{4}{ }^{+}$adsorbed groups, and consequently, hydrogen percentage increases as demonstrated by CHN results presented in Table 5.3.

As $\mathrm{pH}$ increases, the zeta potential decreases up to reach the isoelectric point (IEP) of the precipitate at a $\mathrm{pH}=8.2$ (see Figure 5.8a), which is near the IEP of $\mathrm{Al}(\mathrm{OH})_{3}$ [91] and $\mathrm{AlOOH}$ [92]. At this $\mathrm{pH}$ the redissolution of aluminum 
species occurs into $\mathrm{AlO}_{2}^{-}$ions [26] and further $\mathrm{pH}$ increase allows obtaining a negative zeta potential of the remaining precipitate.

Considering the zeta potential curves of precursors, one can conclude that pAlW-AHC-4.2 and pAlW-AHC-6.0 could be modified by anionic surfactant, while pAlW-4.2 and pAlW-6.0 could be modified by a cationic surfactant to improve the dispersion state of precipitated precursor particles within the reaction medium.

\subsection{5.}

\section{Agglomeration state of $\mathrm{Al}_{2} \mathrm{~W}_{3} \mathrm{O}_{12}$ powders}

To gain insight into the agglomeration state of $\mathrm{Al}_{2} \mathrm{~W}_{3} \mathrm{O}_{12}$ as-synthesized powders, the particle size distributions in number measured by laser diffraction are shown in Figure 5.9. The $\mathrm{d}_{50}$ parameter corresponding to the number median diameter obtained from these distributions is presented in Table 5.4.

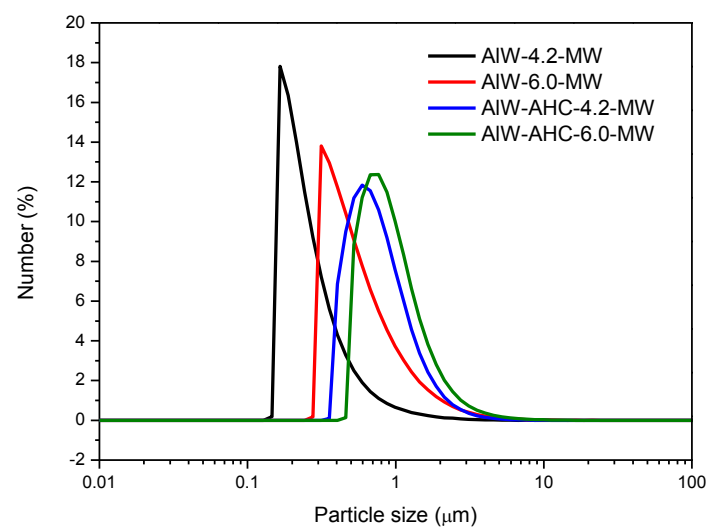

Figure 5.9- Particle size distributions in number of $\mathrm{Al}_{2} \mathrm{~W}_{3} \mathrm{O}_{12}$ calcined powders.

Since agglomerates are an assembly of primary particles, the specific surface area determined using BET method (see Table 5.4), allowed calculation of the mean primary particle size $\left(\mathrm{d}_{\mathrm{BET}}\right)$, assuming particles with spherical shape and using a theoretical density of $5.091 \mathrm{gcm}^{-3}$. Thus, the comparison between mean primary particle sizes and median diameter of agglomerates can give a good insight of the degree of agglomeration. $\mathrm{S}_{\mathrm{BET}}$ values of $\mathrm{Al}_{2} \mathrm{~W}_{3} \mathrm{O}_{12}$ as-synthesized powders are higher than those reported in the literature for $\mathrm{Al}_{2} \mathrm{~W}_{3} \mathrm{O}_{12}$ prepared by combustion method using urea and carbohydrazide derived powders, $0.17 \mathrm{~m}^{2} \mathrm{~g}^{-1}$ and $0.65 \mathrm{~m}^{2} \mathrm{~g}^{-1}$ [18], respectively. In the case of AlW-4.2-MW, $\mathrm{S}_{\mathrm{BET}}$ value is 
comparable with that reported by Jardim et al. [4] $\left(1.2 \mathrm{~m}^{2} \mathrm{~g}^{-1}\right)$ for $\mathrm{Al}_{2} \mathrm{~W}_{3} \mathrm{O}_{12}$ powders synthesized through co-precipitation by mixing reactants at $\mathrm{pH}=6.0$.

Table 5.4- $\mathrm{S}_{\mathrm{BET}}, \mathrm{d}_{\mathrm{BET}}$ and $\mathrm{d}_{50}$ parameters of $\mathrm{Al}_{2} \mathrm{~W}_{3} \mathrm{O}_{12}$ powders.

\begin{tabular}{lccc}
\hline \multicolumn{1}{c}{ Samples } & $\mathrm{S}_{\mathrm{BET}}\left(\mathrm{m}^{2} / \mathrm{g}\right)$ & $\mathrm{d}_{\mathrm{BET}}(\mu \mathrm{m})$ & $\mathrm{d}_{50}(\mu \mathrm{m})$ \\
\hline AlW-4.2-MW & 1.22 & 0.97 & 0.22 \\
AlW-6.0-MW & 6.34 & 0.19 & 0.47 \\
AlW-AHC-4.2-MW & 2.09 & 0.57 & 0.67 \\
AlW-AHC-6.0-MW & 10.57 & 0.11 & 0.81 \\
\hline
\end{tabular}

\subsubsection{1.}

\section{Effect of synthesis pH}

The effect of $\mathrm{pH}$ on zeta potential of $\mathrm{Al}_{2} \mathrm{~W}_{3} \mathrm{O}_{12}$ precursors is reflected in the agglomeration state of the calcined powders. Thus, AlW-AHC-6.0-MW formed agglomerates consisting of primary round particles smaller than those of AlW-AHC-4.2-MW (see Figure 5.10). In addition, these results are in agreement with $\mathrm{d}_{\mathrm{BET}}$ values founded for these two powders.

(a)

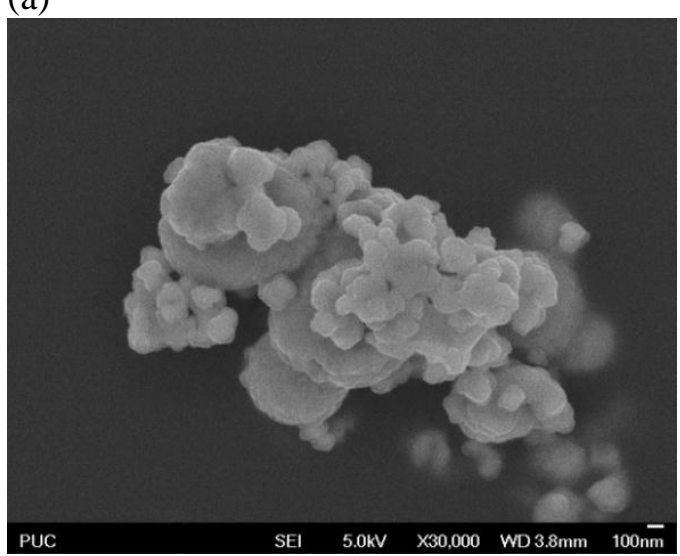

(b)

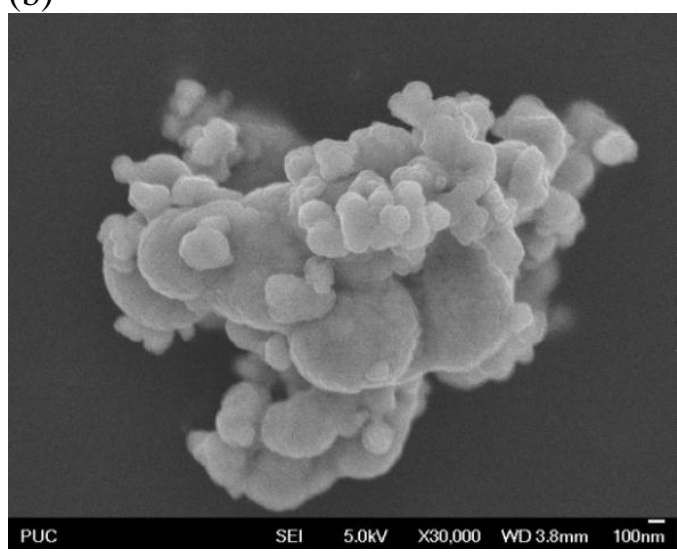

(c)

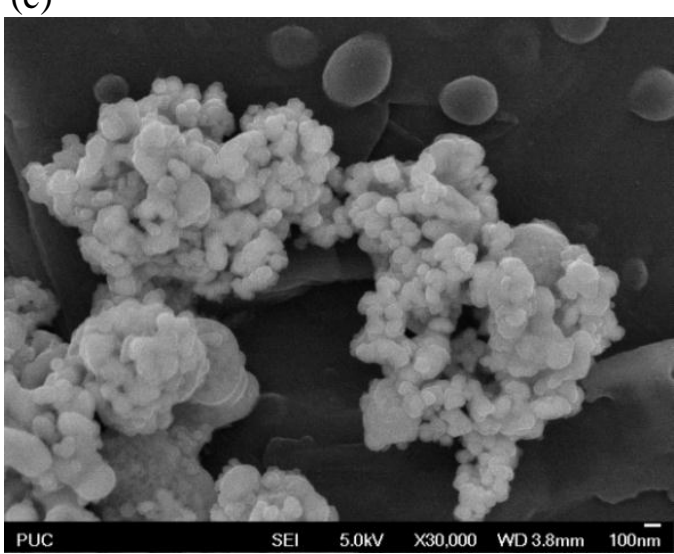

(d)

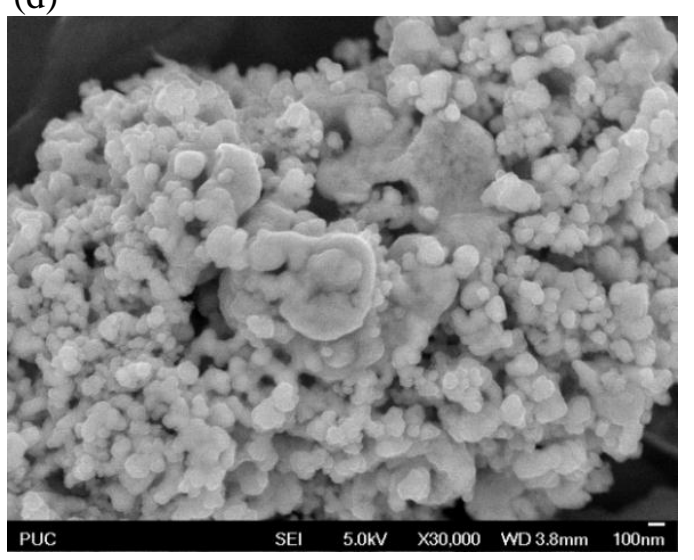

Figure 5.10- FEG-SEM images of (a-b) AIW-AHC-4.2-MW and (c-d) AIW-AHC-6.0-MW. 
Likewise, AlW-6.0-MW powder agglomerates are assembled by a great number of primary particles, as illustrated in Figure 5.11, which should be smaller than those of AlW-4.2-MW at least based on $\mathrm{d}_{\mathrm{BET}}$ results, since FEG-SEM images of this sample were not performed yet. AlW-6.0-MW exhibits a bimodal population of particles: round nanoparticles (even smaller than those of AlWAHC-6.0-MW) and plate-like particles of around 500-700 nm in length, morphology that was previously observed by Jardim et al. [4] for $\mathrm{Al}_{2} \mathrm{~W}_{3} \mathrm{O}_{12}$ powder prepared at $\mathrm{pH}=6.0$ through co-precipitation by mixing reactants, but the precursor was washed with water and oven dried and calcined at $800{ }^{\circ} \mathrm{C}$ for 30 min. On the other hand, $d_{B E T}$ of AlW-4.2-MW powder is higher than $d_{50}$, which suggest that this powder is composed basically by impermeable soft agglomerates that are broken apart during laser diffraction analysis. Higgins et al. [18] reported similar results. In fact, $\mathrm{d}_{\mathrm{BET}}$ value of $\mathrm{Al}_{2} \mathrm{~W}_{3} \mathrm{O}_{12}$ submicronic powder prepared by combustion synthesis was larger than the average particle size observed by DLS, suggesting that this powder is composed by $\mathrm{N}_{2}$ impermeable soft agglomerates fragmented when dispersed in liquid.

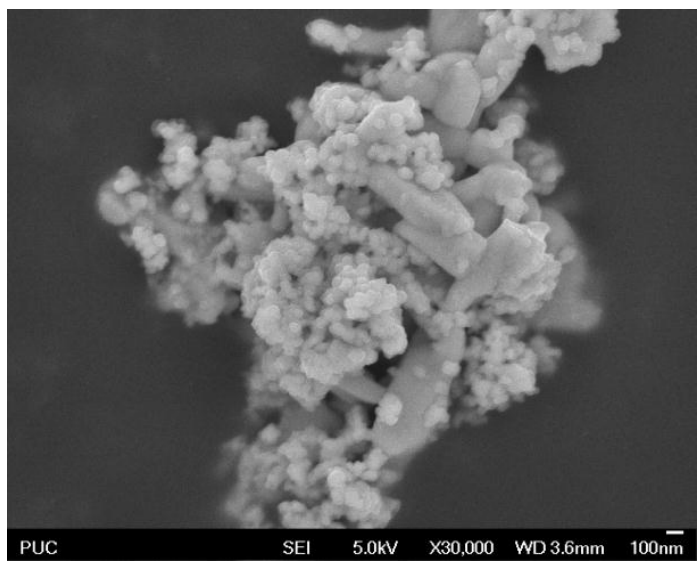

Figure 5.11- FEG-SEM images of AIW-6.0-MW.

Furthermore, powders prepared at $\mathrm{pH}=4.2$ are composed by smaller agglomerates based on $\mathrm{d}_{50}$ parameter when compared with the corresponding powders synthesized at $\mathrm{pH}=6.0$, independent of the co-precipitation method, albeit this difference was more observable for powders prepared via co-precipitation by mixing reactants, as can be seen in Figure 5.9.a. Likely, smaller precursor particles obtained at synthesis $\mathrm{pH}=6.0$ tend to reduce their high specific surface 
area during drying and calcination stage resulting in more agglomerated powders (with larger size) even when they are formed by smaller primary particles. AlW4.2-MW sample possesses the smallest $\mathrm{d}_{50}$ value.

\subsubsection{2.}

\section{Effect of co-precipitation method}

The tungsten source dictated the choice of the co-precipitation method. For the same synthesis $\mathrm{pH}$ powders prepared through co-precipitation by mixing reactants using sodium tungstate allowed obtaining smaller agglomerates (see Figure 5.9.a).

A lower calcination temperature $\left(630^{\circ} \mathrm{C}\right)$ associated with hydroxyl-based precursors synthesized using sodium tungstate could be the explanation for lower $\mathrm{d}_{50}$ parameter. Therefore, the assumption that hydroxycarbonate-based precursors could produce less agglomerated powders was restricted by the higher calcination temperature, whose effect on the agglomeration degree of powders would be more detrimental than the formation of hydrogen bonds between hydroxyl groups during drying.

A summary of effects of the variables studied in this work on the agglomeration state of $\mathrm{Al}_{2} \mathrm{~W}_{3} \mathrm{O}_{12}$ submicronic powders is presented in Figure 5.12

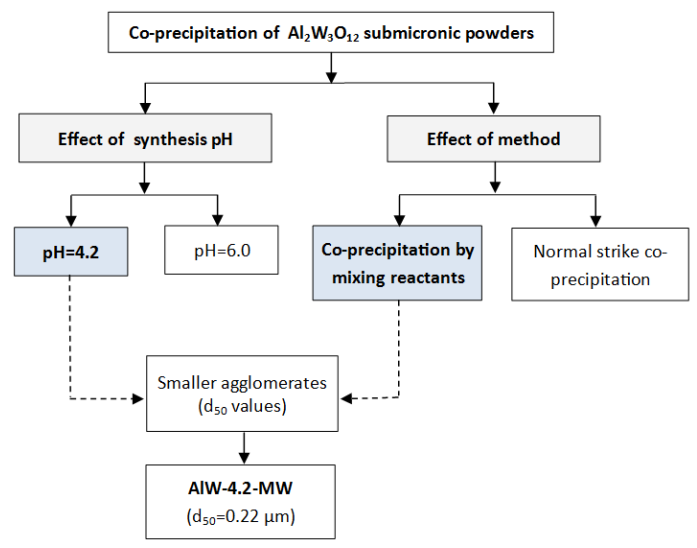

Figure 5.12- Scheme of the effects of the studied variables on the agglomeration state of $\mathrm{Al}_{2} \mathrm{~W}_{3} \mathrm{O}_{12}$ submicronic powders. 


\subsection{6.}

\section{Conclusions}

$\mathrm{Al}_{2} \mathrm{~W}_{3} \mathrm{O}_{12}$ submicronic powders ranging from 0.22 to $0.81 \mu \mathrm{m}$ were prepared via co-precipitation by mixing reactants and normal strike method, at synthesis $\mathrm{pH}=4.2$ and $\mathrm{pH}=6.0$. For both co-precipitation methods, $\mathrm{pH}=6.0$ led to the formation of bigger agglomerates as demonstrated by $\mathrm{d}_{50}$ parameter, but comprising smaller primary particles. The co-precipitation method, dictated by the tungsten source, has a strong influence on the size of agglomerates, because it defines the crystallization and calcination temperatures. Co-precipitation by mixing reactants at $\mathrm{pH}=4.2$ was a more efficient method to produce $\mathrm{Al}_{2} \mathrm{~W}_{3} \mathrm{O}_{12}$ powders with the smallest agglomerate size $(\sim 0.22 \mu \mathrm{m})$. Further FEG-SEM analysis of this sample is necessary to characterize these agglomerates. 


\section{6 \\ Role of $A_{2} M_{3} \mathrm{O}_{12}$ submicronic fillers in improving thermal expansion behavior and mechanical properties of HDPE- based composites}

\section{1. \\ Background}

Polymers expand considerably with the increase of temperature when compared to metals and ceramics. Actually, the high CTEs of thermoplastics restrain their application in engineering areas demanding extremely dimensional stability, such as aerospace and microelectronics industries as well as in structural applications [57]. Therefore, the addition of compounds from $\mathrm{A}_{2} \mathrm{M}_{3} \mathrm{O}_{12}$ family, exhibiting low positive and negative thermal expansion, into thermoplastic matrices can mitigate their high CTEs.

Since data of thermal expansion behavior of polymer composites filled with $\mathrm{A}_{2} \mathrm{M}_{3} \mathrm{O}_{12}$ family members are scarce and $\mathrm{CTE}$ reductions reported for medium density polyethylene composites reinforced with $\mathrm{Al}_{2} \mathrm{Mo}_{3} \mathrm{O}_{12}$ particles are encouraging [1], the development of HDPE-based composites prepared with $\mathrm{Al}_{2} \mathrm{~W}_{3} \mathrm{O}_{12}$ and $\mathrm{Y}_{2} \mathrm{~W}_{3} \mathrm{O}_{12}$ is an important issue for applications of HDPE at high service temperatures. Therefore, the aim of this work is to assess the role of pristine $\mathrm{Al}_{2} \mathrm{~W}_{3} \mathrm{O}_{12}$ and $\mathrm{Y}_{2} \mathrm{~W}_{3} \mathrm{O}_{12}$ submicronic powders, incorporated at the same filler volume fractions, on thermal expansion behavior and mechanical properties of HDPE-based composites.

\section{2.}

\section{Materials and methods}

\subsection{1.}

Synthesis of $\mathrm{A}_{2} \mathrm{M}_{3} \mathrm{O}_{12}$ submicronic fillers

$\mathrm{Al}_{2} \mathrm{~W}_{3} \mathrm{O}_{12}$ was synthesized by normal strike co-precipitation method based on the same procedure described in section 5.2.2, but with the following differences: i) the milky suspension of precipitated particles was aged at room 
temperature for $60 \mathrm{~min}$, ii) the precipitate was microwave dried during $3 \mathrm{~min}$ and iii) the as-calcined powder was ball milled for $98 \mathrm{~min}$ in a SPEX 8000-115 Mixer Mill, using a ball to powder weight ratio of $1.75: 1 . \mathrm{Al}_{2} \mathrm{~W}_{3} \mathrm{O}_{12}$ powders exhibited a specific surface area of $7.7 \mathrm{~m}^{2} \mathrm{~g}^{-1}$ as determined by BET measurements and median diameter $\left(\mathrm{d}_{50}\right)$ of $0.67 \mu \mathrm{m}$ obtained from particle size distribution in number measured by laser diffraction, as shown in Figure C.1 (Appendix C).

$\mathrm{Y}_{2} \mathrm{~W}_{3} \mathrm{O}_{12}$ submicronic powder with a specific surface area of $6.97 \mathrm{~m}^{2} \mathrm{~g}^{-1}$ and $\mathrm{d}_{50}=0.70 \mu \mathrm{m}$ was synthesized by modified reverse strike co-precipitation following the procedure described elsewhere [84]. $\mathrm{Y}_{2} \mathrm{~W}_{3} \mathrm{O}_{12}$ powder was oven dried at $170{ }^{\circ} \mathrm{C}$ for 10 days prior to micro-compounding to assure the use of $\mathrm{Y}_{2} \mathrm{~W}_{3} \mathrm{O}_{12}$ in its orthorhombic phase.

\subsection{2.}

\section{Manufacturing of $\mathrm{HDPE} / \mathrm{A}_{2} \mathrm{M}_{3} \mathrm{O}_{12}$ composites}

HDPE (IA59U3, Braskem) with density $0.960 \mathrm{gcm}^{-3}$ was selected as the matrix. Composites were prepared using a twin-screw micro-extruder (DSM Xplore 5cc Microcompounder), at $190{ }^{\circ} \mathrm{C}$ for $10 \mathrm{~min}$, according to the following procedure: HDPE pellets and $\mathrm{A}_{2} \mathrm{M}_{3} \mathrm{O}_{12}$ filler were mixed during $5 \mathrm{~min}$ at $50 \mathrm{rpm}$ followed by further $5 \mathrm{~min}$ at $100 \mathrm{rpm}$. Afterwards, the extruded composite was fed to a micro-injection molding machine (DSM Xplore $5.5 \mathrm{cc}$ ) to obtain ASTM D638-10 tensile specimens (dog-bone shaped specimens). The injection pressure was set to 7 bar, while the melt and mold temperatures were $185^{\circ} \mathrm{C}$ and $80{ }^{\circ} \mathrm{C}$, respectively. The filler loadings selected for the preparation of $\mathrm{HDPE} / \mathrm{Al}_{2} \mathrm{~W}_{3} \mathrm{O}_{12}$ and $\mathrm{HDPE} / \mathrm{Y}_{2} \mathrm{~W}_{3} \mathrm{O}_{12}$ composites are presented in Table 6.1. For a specific filler content, each composite will be denoted as follows: HDPE/ $\mathrm{A}_{2} \mathrm{M}_{3} \mathrm{O}_{12}$-vol. \%.

Table 6.1- Filler loadings used for the preparation of HDPE $/ \mathrm{A}_{2} \mathrm{M}_{3} \mathrm{O}_{12}$ composites and the corresponding composite nomenclature.

\begin{tabular}{cccl}
\hline \hline $\begin{array}{c}\text { Filler content } \\
\text { (vol. \%) }\end{array}$ & \multicolumn{2}{c}{ Filler content (mass \%) } & \multirow{2}{*}{$\begin{array}{c}\text { Composite } \\
\text { nomenclature }\end{array}$} \\
\cline { 2 - 3 } & $\mathrm{Al}_{2} \mathrm{~W}_{3} \mathrm{O}_{12}$ & $\mathrm{Y}_{2} \mathrm{~W}_{3} \mathrm{O}_{12}$ & \\
\hline \hline 0 & 0 & 0 & $\mathrm{HDPE}$ \\
0.1 & 0.75 & - & $\mathrm{HDPE} / \mathrm{A}_{2} \mathrm{M}_{3} \mathrm{O}_{12}-0.1$ \\
0.3 & 1.5 & 1.4 & $\mathrm{HDPE} / \mathrm{A}_{2} \mathrm{M}_{3} \mathrm{O}_{12}-0.3$ \\
0.6 & 3.0 & 2.8 & $\mathrm{HDPE} / \mathrm{A}_{2} \mathrm{M}_{3} \mathrm{O}_{12}-0.6$ \\
1.1 & 6.0 & 5.6 & $\mathrm{HDPE} / \mathrm{A}_{2} \mathrm{M}_{3} \mathrm{O}_{12}-1.1$ \\
\hline
\end{tabular}




\subsection{3.}

\section{Characterization of $\mathrm{HDPE} / \mathrm{A}_{2} \mathrm{M}_{3} \mathrm{O}_{12}$ composites}

Thermogravimetric analysis (TGA) and differential scanning calorimetry (DSC) of neat HDPE and the as-prepared composites were performed in a PerkinElmer Simultaneous Thermal Analyzer (STA 6000) in nitrogen flux $\left(50 \mathrm{mLmin}^{-1}\right.$ ) in the temperature range between $30{ }^{\circ} \mathrm{C}$ and $650{ }^{\circ} \mathrm{C}$, applying a heating rate of 10 ${ }^{\circ} \mathrm{Cmin}^{-1}$.

Dilatometric studies of neat HDPE and HDPE/ $\mathrm{A}_{2} \mathrm{M}_{3} \mathrm{O}_{12}$ composites were carried out in a NETZSCH dilatometer DIL 402C, in air atmosphere in the temperature range from 25 to $100{ }^{\circ} \mathrm{C}$, with a heating rate of $4{ }^{\circ} \mathrm{Cmin}^{-1}$. Prismatic rod specimens $(3.3 \mathrm{~mm} \times 3.2 \mathrm{~mm} \times 11 \mathrm{~mm}$ ) for dilatometric measurements were manufactured from the central region of tensile specimens. Three separate specimens of each material (neat HDPE and HDPE/ $\mathrm{A}_{2} \mathrm{M}_{3} \mathrm{O}_{12}$ composites) were tested.

Mechanical tests of neat HDPE and HDPE/ $\mathrm{A}_{2} \mathrm{M}_{3} \mathrm{O}_{12}$ composites were conducted on ASTM D638-10 tensile specimens using a Universal Testing Machine EMIC DL 10000 at a crosshead speed separation of $50 \mathrm{mmmin}^{-1}$. Six specimens of each composite material and virgin HDPE were tested.

\section{3.}

Results and discussion

\subsection{1.}

Thermal expansion properties of $\mathrm{HDPE} / \mathrm{A}_{2} \mathrm{M}_{3} \mathrm{O}_{12}$ composites

\subsubsection{1.}

\section{Effect of heating cycles}

CTEs of composites were calculated from the slope of the respective thermal strain curves on heating obtained by dilatometry. Firstly, a specimen of neat HDPE was subjected to three heating cycles, as shown in Figure 6.1.a. It can be seen that curves for the second and third heating cycles are practically identical and overlapped, but differ from the curve of the first heating run. A similar feature was observed in composites filled with both $\mathrm{Al}_{2} \mathrm{~W}_{3} \mathrm{O}_{12}$ and $\mathrm{Y}_{2} \mathrm{~W}_{3} \mathrm{O}_{12}$, as depicted in Figure 6.1.b, for instance, in the case of $\mathrm{HDPE} / \mathrm{Y}_{2} \mathrm{~W}_{3} \mathrm{O}_{12}-1.1$ composite. 
(a)

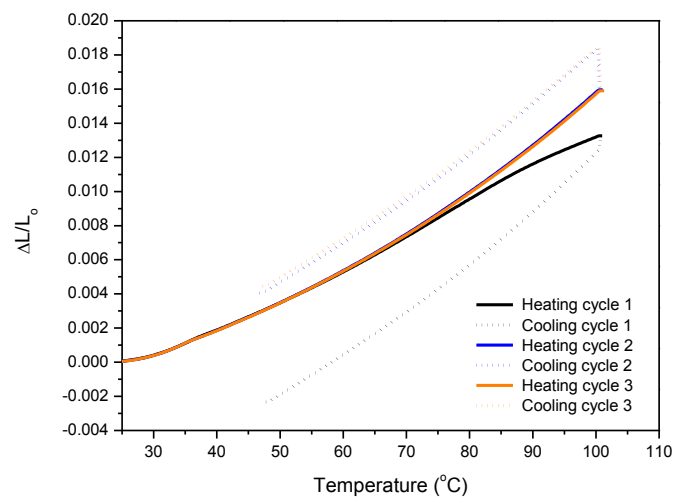

(b)

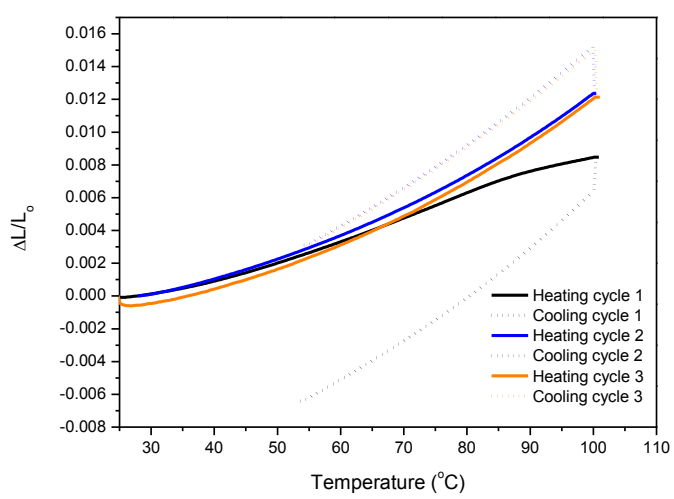

Figure 6.1- Dilatometric curves of (a) neat HDPE and (b) $\mathrm{HDPE} / \mathrm{Y}_{2} \mathrm{~W}_{3} \mathrm{O}_{12}-1.1$ composite specimens subjected to three heating cycles.

The three heating curves exhibit a similar slope up to $70{ }^{\circ} \mathrm{C}$ for each sample (see Figure 6.1). However, for the temperatures higher than $70{ }^{\circ} \mathrm{C} \mathrm{CTE}$ corresponding to the first heating cycle decreases. For this reason, the CTEs of neat HDPE and composites were calculated considering two temperature intervals: $25-70{ }^{\circ} \mathrm{C}$ and $25-100{ }^{\circ} \mathrm{C}$. In the first temperature range, the CTE difference between the first and second heating cycles $(\triangle \mathrm{CTE})$ is merely $2 \%$ for HDPE and 2-8 \% for HDPE/ $\mathrm{Al}_{2} \mathrm{~W}_{3} \mathrm{O}_{12}$ composites, as presented in Table 6.2, while this variation is higher (11-15\%) for $\mathrm{HDPE} / \mathrm{Y}_{2} \mathrm{~W}_{3} \mathrm{O}_{12}$ composites (see Table 6.3). However, these discrepancies between the CTEs in the first and second cycles for neat $\mathrm{HDPE}$ and $\mathrm{HDPE} / \mathrm{Al}_{2} \mathrm{~W}_{3} \mathrm{O}_{12}$ composites are within the standard deviations, as can be observed in Table 6.2

Table 6.2- CTEs of HDPE/ $/ \mathrm{Al}_{2} \mathrm{~W}_{3} \mathrm{O}_{12}$ composites for first and second heating cycles in the temperature range of $25-70^{\circ} \mathrm{C}$.

\begin{tabular}{|c|c|c|c|c|c|}
\hline \multirow[b]{2}{*}{$\begin{array}{l}\text { Filler content } \\
\quad(\text { vol. \%) }\end{array}$} & \multicolumn{2}{|c|}{ Heating cycle 1} & \multicolumn{2}{|c|}{ Heating cycle 2} & \multirow{2}{*}{$\begin{array}{c}\Delta \mathrm{CTE} \\
\text { between first } \\
\text { and second } \\
\text { heating }(\%)\end{array}$} \\
\hline & $\begin{array}{c}\text { CTE } \\
\left(\times 10^{-6}{ }^{\circ} \mathrm{C}^{-1}\right)\end{array}$ & $\begin{array}{c}\mathrm{CTE} \\
\text { reduction } \\
(\%) \\
\end{array}$ & $\begin{array}{c}\text { CTE } \\
\left(\times 10^{-6}{ }^{\circ} \mathrm{C}^{-1}\right)\end{array}$ & $\begin{array}{c}\mathrm{CTE} \\
\text { reduction } \\
(\%) \\
\end{array}$ & \\
\hline 0 & $172 \pm 7$ & - & $175 \pm 6$ & - & 2 \\
\hline 0.1 & $159 \pm 5$ & 7 & $163 \pm 2$ & 7 & 2 \\
\hline 0.3 & $155 \pm 14$ & 9 & $161 \pm 2$ & 8 & 4 \\
\hline 0.6 & $161 \pm 9$ & 6 & $173 \pm 7$ & 1 & 8 \\
\hline 1.1 & $157 \pm 6$ & 8 & $164 \pm 7$ & 7 & 4 \\
\hline
\end{tabular}


Table 6.3- CTEs of HDPE $/ \mathrm{Y}_{2} \mathrm{~W}_{3} \mathrm{O}_{12}$ composites for first and second heating cycles in the temperature range of $25-70^{\circ} \mathrm{C}$.

\begin{tabular}{|c|c|c|c|c|c|}
\hline \multirow[b]{2}{*}{$\begin{array}{l}\text { Filler content } \\
\text { (vol. \%) }\end{array}$} & \multicolumn{2}{|c|}{ Heating cycle 1} & \multicolumn{2}{|c|}{ Heating cycle 2} & \multirow{2}{*}{$\begin{array}{c}\Delta \mathrm{CTE} \\
\text { between first } \\
\text { and second } \\
\text { heating }(\%)\end{array}$} \\
\hline & $\begin{array}{c}\mathrm{CTE} \\
\left(\mathrm{x} 10^{-6}{ }^{\circ} \mathrm{C}^{-1}\right)\end{array}$ & $\begin{array}{c}\mathrm{CTE} \\
\text { reduction } \\
(\%)\end{array}$ & $\begin{array}{c}\text { CTE } \\
\left(\times 10^{-6}{ }^{\circ} \mathrm{C}^{-1}\right)\end{array}$ & $\begin{array}{c}\mathrm{CTE} \\
\text { reduction } \\
(\%)\end{array}$ & \\
\hline 0 & $172 \pm 7$ & - & $175 \pm 6$ & - & 2 \\
\hline 0.1 & - & - & & - & - \\
\hline 0.3 & $119 \pm 2$ & 31 & $136 \pm 3$ & 22 & 15 \\
\hline 0.6 & $122 \pm 1$ & 29 & $140 \pm 11$ & 20 & 15 \\
\hline 1.1 & $117 \pm 12$ & 32 & $131 \pm 1$ & 25 & 11 \\
\hline
\end{tabular}

However, taking into account the temperature range from 25 to $100{ }^{\circ} \mathrm{C}$, $\triangle$ CTEs between first and second heating cycles are considerably higher than those values reported for the temperature interval between 25 to $70{ }^{\circ} \mathrm{C}$ not only for HDPE but also for HDPE/ $\mathrm{Al}_{2} \mathrm{~W}_{3} \mathrm{O}_{12}$ and $\mathrm{HDPE} / \mathrm{Y}_{2} \mathrm{~W}_{3} \mathrm{O}_{12}$ composites (see Table 6.4 and Table 6.5).

Table 6.4- CTEs of HDPE/Al $\mathrm{H}_{3} \mathrm{O}_{12}$ composites for first and second heating cycles in the temperature range of $25-100^{\circ} \mathrm{C}$.

\begin{tabular}{|c|c|c|c|c|c|}
\hline \multirow[b]{2}{*}{$\begin{array}{l}\text { Filler content } \\
\quad(\text { vol. } \%)\end{array}$} & \multicolumn{2}{|c|}{ Heating cycle 1} & \multicolumn{2}{|c|}{ Heating cycle 2} & \multirow{2}{*}{$\begin{array}{c}\Delta \mathrm{CTE} \\
\text { between first } \\
\text { and second } \\
\text { heating }(\%)\end{array}$} \\
\hline & $\begin{array}{c}\text { CTE } \\
\left(\times 10^{-6}{ }^{\circ} \mathrm{C}^{-1}\right)\end{array}$ & $\begin{array}{c}\mathrm{CTE} \\
\text { reduction } \\
(\%) \\
\end{array}$ & $\begin{array}{c}\mathrm{CTE} \\
\left(\mathrm{x} 10^{-6}{ }^{\circ} \mathrm{C}^{-1}\right)\end{array}$ & $\begin{array}{c}\mathrm{CTE} \\
\text { reduction } \\
(\%) \\
\end{array}$ & \\
\hline 0 & $183 \pm 7$ & - & $221 \pm 6$ & - & 21 \\
\hline 0.1 & $162 \pm 3$ & 11 & $204 \pm 4$ & 8 & 26 \\
\hline 0.3 & $165 \pm 2$ & 10 & $214 \pm 11$ & 3 & 30 \\
\hline 0.6 & $161 \pm 7$ & 12 & $218 \pm 7$ & 1 & 36 \\
\hline 1.1 & $158 \pm 3$ & 14 & $208 \pm 6$ & 6 & 32 \\
\hline
\end{tabular}

Table 6.5- CTEs of HDPE $/ \mathrm{Y}_{2} \mathrm{~W}_{3} \mathrm{O}_{12}$ composites for first and second heating cycles in the temperature range of $25-100{ }^{\circ} \mathrm{C}$.

\begin{tabular}{|c|c|c|c|c|c|}
\hline \multirow[b]{2}{*}{$\begin{array}{l}\text { Filler content } \\
\text { (vol. \%) }\end{array}$} & \multicolumn{2}{|c|}{ Heating cycle 1} & \multicolumn{2}{|c|}{ Heating cycle 2} & \multirow{2}{*}{$\begin{array}{c}\Delta \mathrm{CTE} \\
\text { between firs } \\
\text { and second } \\
\text { heating }(\%)\end{array}$} \\
\hline & $\begin{array}{c}\mathrm{CTE} \\
\left(\times 10^{-6}{ }^{\circ} \mathrm{C}^{-1}\right)\end{array}$ & $\begin{array}{c}\text { CTE } \\
\text { reduction } \\
(\%) \\
\end{array}$ & $\begin{array}{c}\mathrm{CTE} \\
\left(\times 10^{-6}{ }^{\circ} \mathrm{C}^{-1}\right)\end{array}$ & $\begin{array}{c}\text { CTE } \\
\text { reduction } \\
(\%) \\
\end{array}$ & \\
\hline 0 & $183 \pm 7$ & - & $221 \pm 6$ & - & 21 \\
\hline 0.1 & - & - & - & - & - \\
\hline 0.3 & $146 \pm 12$ & 20 & $181 \pm 2$ & 18 & 23 \\
\hline 0.6 & $136 \pm 10$ & 26 & $185 \pm 3$ & 16 & 36 \\
\hline 1.1 & $133 \pm 7$ & 27 & $173 \pm 2$ & 22 & 30 \\
\hline
\end{tabular}


The differences between CTEs computed for the first and second heating cycles, mainly in the temperature range of $25-100{ }^{\circ} \mathrm{C}$, could be ascribed to the release of the residual tensile thermal stresses induced during injection molding process. Indeed, for semi-crystalline thermoplastic-based composites, the processing history has implications on the embedded residual stresses, which can be completely released when the composite is annealed at a temperature higher than glass transition temperature of the matrix but below its melting point [93], namely, between -110 and $135{ }^{\circ} \mathrm{C}$ for HDPE [94]. Actually, all the specimens were practically annealed during the first heating cycle up to $100{ }^{\circ} \mathrm{C}$. As a result, the length of specimens decreased $\sim 0.4-0.9 \%$, suggesting that residual stresses were released at the end of first heating run and no further shrinkage of specimens was observed during second and third heating cycles. Neither the cross section of prismatic rod specimens nor their mass underwent any change at the end of first, second and third heating cycling. Therefore, the density of HDPE and composites should be increased during the first heating cycle, as a consequence of an increase on crystallinity degree. This was verified by DSC analysis of HDPE and $\mathrm{HDPE} / \mathrm{Y}_{2} \mathrm{~W}_{3} \mathrm{O}_{12}$ composite specimens before the first heating cycle and after being subjected to the second heating run in dilatometer, and the results of crystallinity degree are presented in section 6.3.2 and Table C. 1 (Appendix C), respectively. The computation of crystallinity degree is also described in section 6.3.2. In spite of the fact that the crystallinity degree was increased by thermal cycling, the CTEs of neat $\mathrm{HDPE}$ and $\mathrm{HDPE} / \mathrm{Y}_{2} \mathrm{~W}_{3} \mathrm{O}_{12}$ composites measured during the second heating run were higher than those calculated from first heating cycle. Accordingly, the release of residual tensile thermal stresses is responsible for that thermal expansion feature.

It is important to point out that there is a lack of information in the literature in respect to the assessment of CTE of composites filled with thermomiotics during different heating cycles and commonly it is assumed that CTE is measured for the first heating run because no additional information concerning to heating cycles is presented when dilatometric studies are carried out [1, 21, 43, 48]. When CTE is determined by thermomechanical analysis (TMA) only a few works reported this value for the second heating cycle [95]. 


\subsubsection{2. \\ Effect of $A_{2} M_{3} O_{12}$ phase and filler content}

The addition of $\mathrm{Y}_{2} \mathrm{~W}_{3} \mathrm{O}_{12}$ and $\mathrm{Al}_{2} \mathrm{~W}_{3} \mathrm{O}_{12}$ fillers to HDPE resulted in a reduction of CTE compared to the neat matrix, during first and posterior heating cycles in the selected temperature ranges. $\mathrm{Y}_{2} \mathrm{~W}_{3} \mathrm{O}_{12}$ acts more efficiently to decrease the CTE of polymer matrix than $\mathrm{Al}_{2} \mathrm{~W}_{3} \mathrm{O}_{12}$. Thus, the CTE reductions for $\mathrm{HDPE} / \mathrm{Y}_{2} \mathrm{~W}_{3} \mathrm{O}_{12}$ in the temperature range of $25-70{ }^{\circ} \mathrm{C}$ were $\sim 29-32 \%$ and 20 $25 \%$ for the first and second heating cycles, respectively (see Table 6.3). CTE of composites also decreased in the temperature interval between $25-100{ }^{\circ} \mathrm{C}$ and the CTE reductions were independent of filler content, as indicated in Table 6.5.

On the other hand, $\mathrm{HDPE} / \mathrm{Al}_{2} \mathrm{~W}_{3} \mathrm{O}_{12}$ composites displayed a reduction on CTE of $\sim 6-9 \%$ compared to neat HDPE in the temperature range of $25-70{ }^{\circ} \mathrm{C}$ and similar decreases on CTE in the second heating cycle, regardless of filler content (see Table 6.2). The only exception was $\mathrm{HDPE} / \mathrm{Al}_{2} \mathrm{~W}_{3} \mathrm{O}_{12}-0.6$, whose CTE practically remains the same of matrix in both temperature intervals. A further decrease on CTE of $\mathrm{HDPE} / \mathrm{Al}_{2} \mathrm{~W}_{3} \mathrm{O}_{12}(10-14 \%)$ in between $25-100{ }^{\circ} \mathrm{C}$ was attained for heating run 1 nearly independent of filler content, while CTE reductions during the second run were smaller, as presented in Table 6.4.

Experimental CTE values of HDPE and composites, measured in the temperature range of $25-70{ }^{\circ} \mathrm{C}$ during the first heating cycle, were compared with predicted values computed from equations listed in Table 2.2 and using the parameters presented in Table 6.6. These results are shown in Figure 6.2. The use of experimental CTEs measured during the first heating run can be justified considering that elastic properties of matrix may be affected by heating cycling (i.e. Young's modulus, which could be affected by crystallinity degree). 
Table 6.6- Parameters required for application of models for prediction of CTEs of composites.

\begin{tabular}{|c|c|c|}
\hline Parameters & Values & Comments \\
\hline$\alpha_{m}$ & $183 \times 10^{-6}{ }^{\circ} \mathrm{C}^{-1}$ & $\begin{array}{l}\text { Value measured by dilatometry, } \\
\text { first heating }\left(25-100^{\circ} \mathrm{C}\right)\end{array}$ \\
\hline$\alpha_{A l 2 W 3 O 12}$ & $1.75 \times 10^{-6}{ }^{\circ} \mathrm{C}^{-1}$ & [19] \\
\hline$\alpha_{Y 2 W 3 O 12}$ & $-7.0 \times 10^{-6}{ }^{\circ} \mathrm{C}^{-1}$ & [5] \\
\hline$E_{m}$ & $0.824 \mathrm{GPa}$ & Value obtained from tensile test \\
\hline$K_{m}$ & $0.824 \mathrm{GPa}$ & Value calculated from Eq. 2.13 \\
\hline$G_{m}$ & $0.309 \mathrm{GPa}$ & Value calculated from Eq. 2.14 \\
\hline$G_{A l 2 W 3 O 12}$ & $39 \mathrm{GPa}$ & [96] \\
\hline$G_{Y_{213} \mathrm{OII}^{\dagger}}^{\dagger}$ & $\sim 12 \mathrm{GPa}$ & [97] \\
\hline$K_{\mathrm{Al2W} 3 \mathrm{O} / 2}$ & $48 \mathrm{GPa}$ & [98] \\
\hline$K_{Y 2 W 3 O 12}$ & $25 \mathrm{GPa}$ & [99] \\
\hline
\end{tabular}

${ }^{\dagger} G_{Y_{2} W_{3} O_{12}}$ is unavailable in the literature. It was assumed that $G_{Y_{2} W_{3} O_{12}} \sim G_{Y_{2} M_{3} O_{12}}$, since bulk moduli of both materials are similar $\left(K_{\mathrm{Y}_{2} \mathrm{Mo}_{3} \mathrm{O}_{12}}=21 \mathrm{GPa}\right)$.

(a)

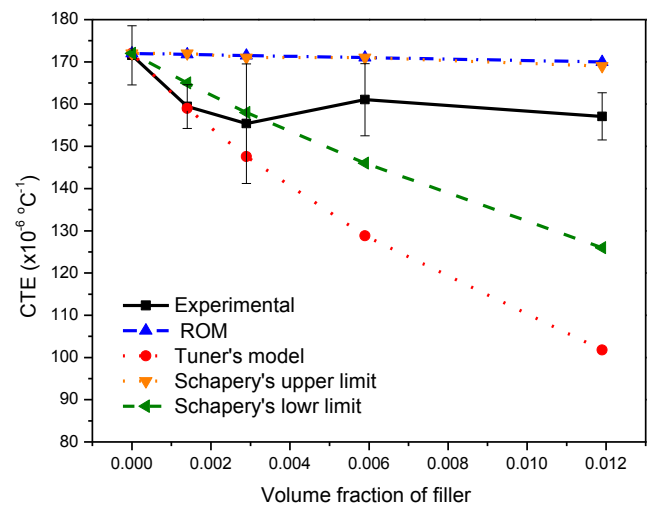

(b)

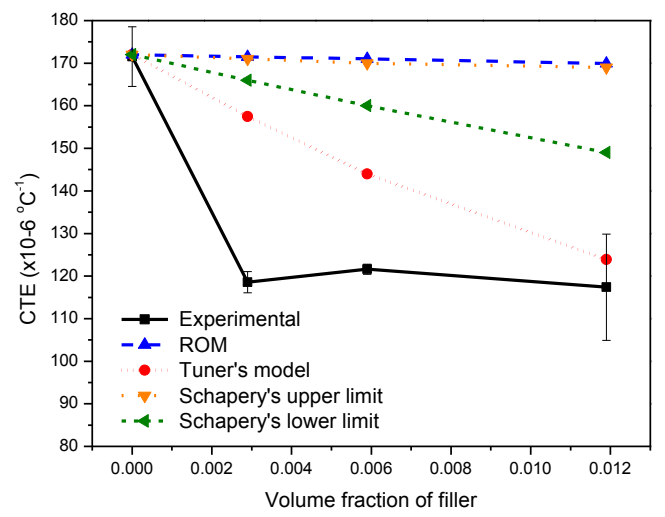

Figure 6.2.- Experimental and predicted CTEs of (a) $\mathrm{HDPE} / \mathrm{Al}_{2} \mathrm{~W}_{3} \mathrm{O}_{12}$ and (b) $\mathrm{HDPE} / \mathrm{Y}_{2} \mathrm{~W}_{3} \mathrm{O}_{12}$ composites. Experimental values were measured in the temperature range of $25-70{ }^{\circ} \mathrm{C}$ and during the first heating cycle.

Experimental CTEs of $\mathrm{HDPE} / \mathrm{Al}_{2} \mathrm{~W}_{3} \mathrm{O}_{12}$ and $\mathrm{HDPE} / \mathrm{Y}_{2} \mathrm{~W}_{3} \mathrm{O}_{12}$ composites are smaller than those predicted by ROM. In the case of $\mathrm{HDPE} / \mathrm{Al}_{2} \mathrm{~W}_{3} \mathrm{O}_{12}$, the CTEs of composites are basically independent of filler content (see Figure 6.2.a), as stated before, and $\mathrm{Al}_{2} \mathrm{~W}_{3} \mathrm{O}_{12}$ loadings above 0.1 vol. \% did not result in an 
increased level of polymer motion constraint. Likely, agglomeration of $\mathrm{Al}_{2} \mathrm{~W}_{3} \mathrm{O}_{12}$ particles inside the HDPE matrix at filler loadings higher than 0.1 vol. \% might affect the dispersion of them and decrease the effect of the low positive CTE of this filler on the overall thermal expansion of $\mathrm{HDPE} / \mathrm{Al}_{2} \mathrm{~W}_{3} \mathrm{O}_{12}$ composites. Thus, the selected models do not fit the experimental CTE data.

Experimental CTE values of $\mathrm{HDPE} / \mathrm{Y}_{2} \mathrm{~W}_{3} \mathrm{O}_{12}$ composites are lower than those estimated from the three models, but for a filler content of $1.1 \mathrm{vol}$. \% the CTE practically matches the predicted value computed using Turner's model bearing in mind the corresponding standard deviation, as shown in Figure 6.2.b. A similar trend was observed in medium density polyethylene composites filled with $\mathrm{Al}_{2} \mathrm{Mo}_{3} \mathrm{O}_{12}$ silanized nanoparticles, where experimental CTE values were fitted using Turner's approach [1]. For volume percentages of $\mathrm{Al}_{2} \mathrm{Mo}_{3} \mathrm{O}_{12}$ silanized nanoparticles of 0.3, 0.6 and $1.1 \%$, the CTE of composites dropped 7, 21 and 46 $\%$, respectively, when compared with that of the neat matrix [1]. The extent of CTE reductions for the same volume fractions of filler was greater for $\mathrm{HDPE} / \mathrm{Y}_{2} \mathrm{~W}_{3} \mathrm{O}_{12}$ (see Table 6.5), with the exception of 1.1 vol. $\%$ of filler loading, which suggests that it is more difficult to achieve a homogeneous dispersion of $\mathrm{Y}_{2} \mathrm{~W}_{3} \mathrm{O}_{12}$ within HDPE matrix for filler contents higher than 0.6 vol. $\%$. It is worth noting that the reductions on CTE of $\mathrm{HDPE} / \mathrm{Y}_{2} \mathrm{~W}_{3} \mathrm{O}_{12}$ composites, ranging from 20 to $27 \%$, were attained for filler volume fractions extremely low compared with those reported for polymer composites reinforced with $\mathrm{ZrW}_{2} \mathrm{O}_{8}$ powders (see Table 2.1) and without any chemical modification of $\mathrm{Y}_{2} \mathrm{~W}_{3} \mathrm{O}_{12}$ surface.

Furthermore, it would be expected that the effect of $\mathrm{Al}_{2} \mathrm{~W}_{3} \mathrm{O}_{12}$ powder on the reduction of CTE of composites would be more remarkable than in the case of $\mathrm{Al}_{2} \mathrm{Mo}_{3} \mathrm{O}_{12}$ filler, because the former is in the orthorhombic phase, which displays a lower CTE. Moreover, the bulk modulus of $\mathrm{Al}_{2} \mathrm{~W}_{3} \mathrm{O}_{12}(\mathrm{~K}=48 \mathrm{GPa}$ [98]) is higher than that of $\mathrm{Al}_{2} \mathrm{Mo}_{3} \mathrm{O}_{12}(\mathrm{~K}=13.6 \mathrm{GPa}$ [1] $)$ and $\mathrm{Y}_{2} \mathrm{Mo}_{3} \mathrm{O}_{12}(\mathrm{~K}=25 \mathrm{GPa}$ [99]). Thus, a greater decrease on CTE of $\mathrm{HDPE} / \mathrm{Al}_{2} \mathrm{~W}_{3} \mathrm{O}_{12}$ would be predicted by Turner's model approach, as can be seen in Figure 6.2.a, but it was not reflected on experimental CTEs of these composites. It reveals that the agglomeration of filler inside the matrix, consequently their dispersion state, plays an important role to control the thermal expansion of composites besides thermal expansion and mechanical properties of filler. Even when particle sizes of $\mathrm{Y}_{2} \mathrm{~W}_{3} \mathrm{O}_{12}$ and 
$\mathrm{Al}_{2} \mathrm{~W}_{3} \mathrm{O}_{12}$ powders are similar, the dispersion state in polymer matrix due to shear forces imposed during the extrusion process could be different for each powder and likely $\mathrm{Y}_{2} \mathrm{~W}_{3} \mathrm{O}_{12}$ particles achieved a more homogenous distribution within the HDPE matrix, providing a more efficient mechanical constraint to motion of polymer chains. Another important factor that should be taken into account to attain strong reductions on CTE of composites is the filler-matrix interactions at the interface [1]. Since $\mathrm{Y}_{2} \mathrm{~W}_{3} \mathrm{O}_{12}$ and $\mathrm{Al}_{2} \mathrm{~W}_{3} \mathrm{O}_{12}$ fillers were not surface treated, the interfacial bonding between fillers and matrix would be merely by mechanical interlocking due to the surface roughness of fillers. Therefore, efficient fillermatrix interactions between $\mathrm{Y}_{2} \mathrm{~W}_{3} \mathrm{O}_{12}$ and HDPE matrix might be also contribute to strong CTE reduction exhibited by $\mathrm{HDPE} / \mathrm{Y}_{2} \mathrm{~W}_{3} \mathrm{O}_{12}$ composites.

\subsection{2.}

\section{Thermal stability of $\mathrm{HDPE} / \mathrm{A}_{2} \mathrm{M}_{3} \mathrm{O}_{12}$ composites}

The thermal properties of $\mathrm{HDPE} / \mathrm{Al}_{2} \mathrm{~W}_{3} \mathrm{O}_{12}$ and $\mathrm{HDPE} / \mathrm{Y}_{2} \mathrm{~W}_{3} \mathrm{O}_{12}$ composites are shown in Table 6.7 and Table 6.8, respectively. TG curves of neat HDPE and composites are presented in Figure C.2 (Appendix C), while DSC curves of HDPE/ $\mathrm{Al}_{2} \mathrm{~W}_{3} \mathrm{O}_{12}$ and $\mathrm{HDPE} / \mathrm{Y}_{2} \mathrm{~W}_{3} \mathrm{O}_{12}$ composites are shown in Figure C.3 and Figure C.4 (Appendix C), respectively. The onset temperature $\left(\mathrm{T}_{\text {onset }}\right)$, which represents the beginning of thermal degradation, did not exhibit a significant change after the incorporation of both fillers. This trend was also observed for the temperature of maximum rate of degradation $\left(\mathrm{T}_{\text {max.degrad. }}\right)$, calculated from the first derivative of TG curves, as well as, for melting temperature $\left(\mathrm{T}_{\mathrm{m}}\right)$ corresponding to the maximum of the peak associated with melting in DSC curves. The parameter $\mathrm{T}_{10}$ that corresponds to the temperature of $10 \%$ mass loss was also unchanged for all the manufactured composites. 
Table 6.7- Thermal properties of $\mathrm{HDPE} / \mathrm{Al}_{2} \mathrm{~W}_{3} \mathrm{O}_{12}$ composites.

\begin{tabular}{cccccccc}
\hline $\begin{array}{c}\text { Filler content } \\
(\text { vol.\%) }\end{array}$ & $\mathrm{T}_{\text {onset }}\left({ }^{\circ} \mathrm{C}\right)$ & $\begin{array}{c}\mathrm{T}_{\text {max.degrad. }} \\
\left({ }^{\circ} \mathrm{C}\right)\end{array}$ & $\begin{array}{c}\mathrm{T}_{\mathrm{m}} \\
\left({ }^{\circ} \mathrm{C}\right)\end{array}$ & $\mathrm{T}_{10}\left({ }^{\circ} \mathrm{C}\right)$ & $\Delta \mathrm{H}\left(\mathrm{Jg}^{-1}\right)$ & $\mathrm{X}_{\mathrm{c}}(\%)$ & $\begin{array}{c}\Delta \mathrm{Xc} \\
(\%)\end{array}$ \\
\hline \hline 0.0 & 472 & 491 & 146 & 465 & 136.67 & 46.5 & 0.0 \\
0.1 & 473 & 491 & 146 & 466 & 145.06 & 49.8 & 6.5 \\
0.3 & 470 & 491 & 140 & 465 & 148.09 & 51.2 & 9.1 \\
0.6 & 471 & 490 & 147 & 465 & 148.73 & 52.2 & 10.9 \\
1.1 & 471 & 493 & 145 & 466 & 141.91 & 51.4 & 9.5 \\
\hline
\end{tabular}

Table 6.8- Thermal properties of $\mathrm{HDPE} / \mathrm{Y}_{2} \mathrm{~W}_{3} \mathrm{O}_{12}$ composites.

\begin{tabular}{cccccccc}
\hline $\begin{array}{c}\text { Filler content } \\
(\text { vol. \%) }\end{array}$ & $\mathrm{T}_{\text {onset }}\left({ }^{\circ} \mathrm{C}\right)$ & $\begin{array}{c}\mathrm{T}_{\text {max.degrad. }} \\
\left({ }^{\circ} \mathrm{C}\right)\end{array}$ & $\begin{array}{r}\mathrm{T}_{\mathrm{m}} \\
\left({ }^{\circ} \mathrm{C}\right)\end{array}$ & $\mathrm{T}_{10}\left({ }^{\circ} \mathrm{C}\right)$ & $\Delta H\left(\mathrm{Jg}^{-1}\right)$ & $X_{c}(\%)$ & $\begin{array}{c}\Delta X c \\
(\%)\end{array}$ \\
\hline 0.0 & 472 & 491 & 146 & 465 & 136.7 & 46.5 & 0.0 \\
0.3 & 470 & 491 & 147 & 464 & 140.9 & 48.7 & 4.3 \\
0.6 & 470 & 491 & 144 & 466 & 149.4 & 52.3 & 11.1 \\
1.1 & 475 & 493 & 147 & 466 & 154.9 & 55.9 & 16.7 \\
\hline
\end{tabular}

The degree of crystallinity $\left(X_{c}\right)$ of neat and as-prepared composites was calculated using Equation 6.1.

$X_{c}=\frac{\Delta H}{\Delta H^{*}\left(1-m_{f}\right)}$

where, $\Delta H$ is the enthalpy change of melting, $\Delta H^{*}=293.6 \mathrm{Jg}^{-1}$ for completely crystallized HDPE [100] and $m_{f}$ is the mass fraction of filler.

$X_{c}$ of composites was strongly affected by the presence of $\mathrm{Y}_{2} \mathrm{~W}_{3} \mathrm{O}_{12}$ particles and increased $\sim 4.3-16.7 \%$ when compared with neat HDPE (see $\Delta X c$ values in Table 6.8) as a function of filler content. Therefore, these fillers act as heterogeneous nucleation sites, increasing the crystallinity content of HDPE matrix. Indeed, the increase on $X_{c}$ of $\mathrm{HDPE} / \mathrm{Y}_{2} \mathrm{~W}_{3} \mathrm{O}_{12}$ was reflected on their CTE values, which were lower than that of neat HDPE (see Table 6.3 and Table 6.5).

$\mathrm{HDPE} / \mathrm{Al}_{2} \mathrm{~W}_{3} \mathrm{O}_{12}$ composites also exhibited an increase on $X_{c}$ ranging from 6.5 to 10.9 as shown in Table 6.7. Filler contents in between 0.3 and 1.1 vol. $\%$ gave rise to similar increments on $X_{c}$, which led to similar CTE reductions for composites prepared at these filler contents (see Table 6.2 and Table 6.4). 


\subsection{3. \\ Mechanical properties of HDPE/ $\mathrm{A}_{2} \mathrm{M}_{3} \mathrm{O}_{12}$ composites}

The increase on the degree of crystallinity after the addition of fillers into HDPE matrix was also reflected on the enhancement of Young's moduli of HDPE-based composites. Indeed, this property was increased for all the composites prepared with both fillers (see Figure 6.3) and $\mathrm{HDPE} / \mathrm{Y}_{2} \mathrm{~W}_{3} \mathrm{O}_{12}$ composites displayed larger increments of $\sim 11$ and $32 \%$ for volume fractions of filler of 0.003 and 0.011 , respectively. It is important to point out that the extent of increase on Young's Moduli of $\mathrm{HDPE} / \mathrm{Al}_{2} \mathrm{~W}_{3} \mathrm{O}_{12}$ composites is in the similar range reported for analogous medium density polyethylene $/ \mathrm{Al}_{2} \mathrm{Mo}_{3} \mathrm{O}_{12}$ composites (6.6 to $19.1 \%$ ) [1] at the same filler volume fractions, but the surface of $\mathrm{Al}_{2} \mathrm{Mo}_{3} \mathrm{O}_{12}$ fillers was treated with a silane coupling agent. On the other hand, bearing in mind polyimide composites reinforced with pristine $\mathrm{ZrW}_{2} \mathrm{O}_{8}$ nanoparticles at filler loadings of $10 \mathrm{vol}$. \%, Young's moduli of those composites only increased $14 \%$ with respect to virgin matrix. The stress-strain curves for one specimen of each type of composite, from which the Young's moduli were calculated, are presented in Figure C.5 and Figure C.6 (see Appendix C) for $\mathrm{HDPE} / \mathrm{Al}_{2} \mathrm{~W}_{3} \mathrm{O}_{12}$ and $\mathrm{HDPE} / \mathrm{Y}_{2} \mathrm{~W}_{3} \mathrm{O}_{12}$, respectively.

(a)

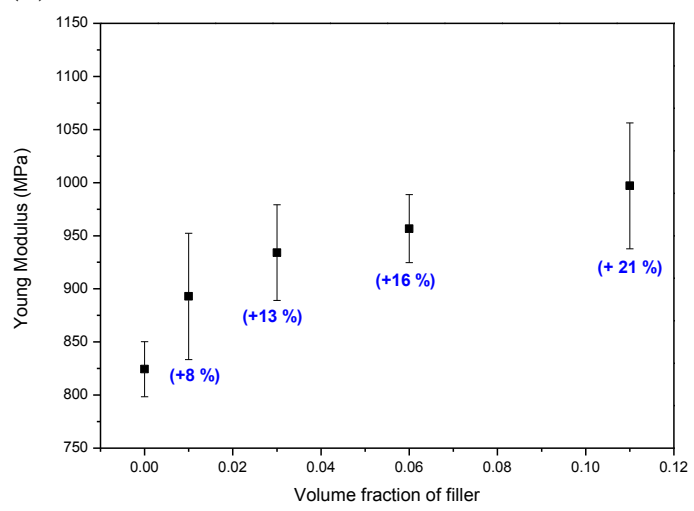

(b)

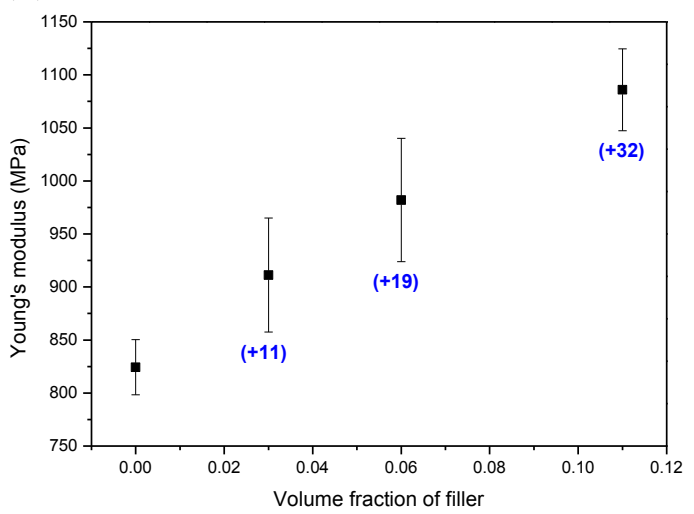

Figure 6.3- Young's moduli of (a) $\mathrm{HDPE} / \mathrm{Al}_{2} \mathrm{~W}_{3} \mathrm{O}_{12}$ and (b) $\mathrm{HDPE} / \mathrm{Y}_{2} \mathrm{~W}_{3} \mathrm{O}_{12}$ composites.

Moreover, the yield stress of $\mathrm{HDPE} / \mathrm{Al}_{2} \mathrm{~W}_{3} \mathrm{O}_{12}$ composites was increased in between 6-8 \% (see Figure 6.4.a), following a similar trend of that observed for medium density polyethylene $/ \mathrm{Al}_{2} \mathrm{Mo}_{3} \mathrm{O}_{12}$ composites [1], while yield stress of 
HDPE matrix was maintained for $\mathrm{HDPE} / \mathrm{Y}_{2} \mathrm{~W}_{3} \mathrm{O}_{12}$ composites as illustrated in Figure 6.4.b.

(a)

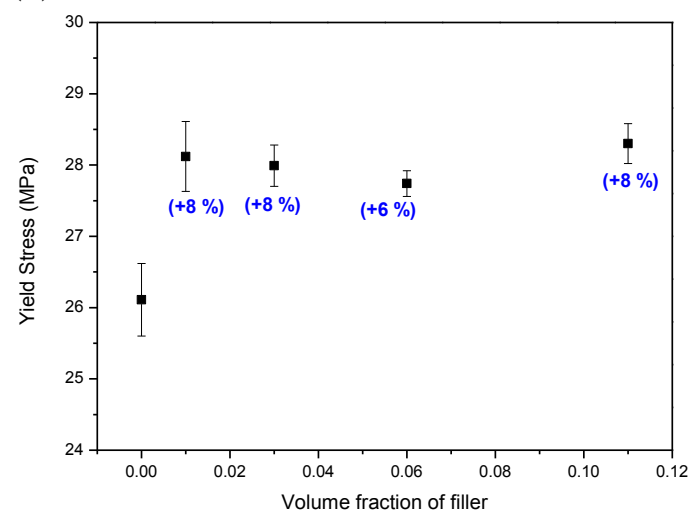

(b)

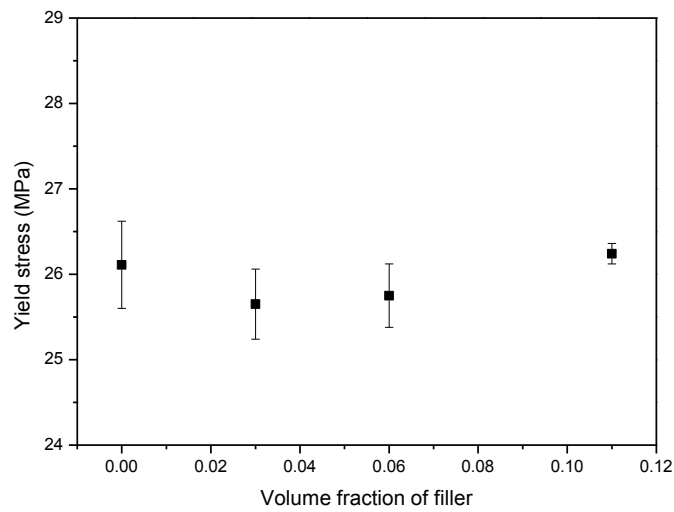

Figure 6.4- Yield stress of (a) $\mathrm{HDPE} / \mathrm{Al}_{2} \mathrm{~W}_{3} \mathrm{O}_{12}$ and (b) $\mathrm{HDPE} / \mathrm{Y}_{2} \mathrm{~W}_{3} \mathrm{O}_{12}$ composites.

Regarding to the yield strain, this property decreased for all the composites, which is consistent with the increase in the stiffness thereof, as presented in Figure 6.5.

(a)

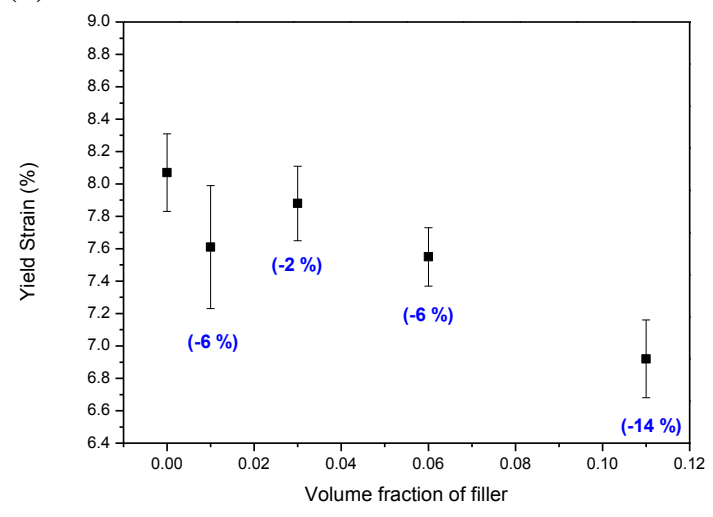

(b)

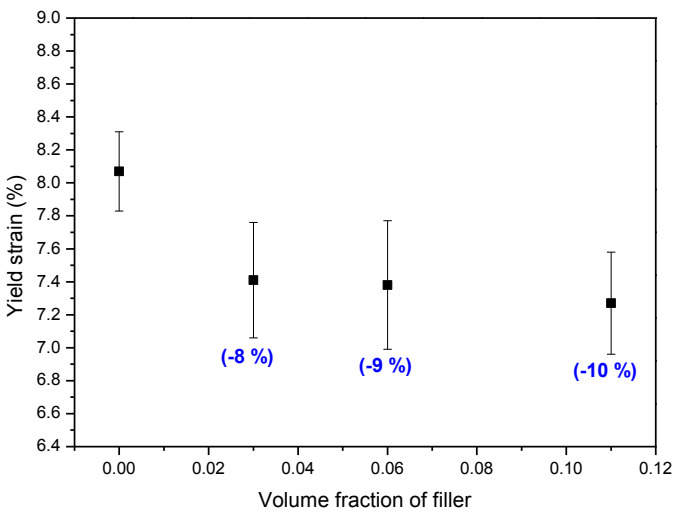

Figure 6.5- Yield strain of (a) $\mathrm{HDPE} / \mathrm{Al}_{2} \mathrm{~W}_{3} \mathrm{O}_{12}$ and (b) $\mathrm{HDPE} / \mathrm{Y}_{2} \mathrm{~W}_{3} \mathrm{O}_{12}$ composites.

\section{4.}

\section{Conclusions}

HDPE-based composites filled with pristine $\mathrm{Al}_{2} \mathrm{~W}_{3} \mathrm{O}_{12}$ and $\mathrm{Y}_{2} \mathrm{~W}_{3} \mathrm{O}_{12}$ submicronic powders, exhibiting improved stiffness and reduced thermal expansion, were prepared in this work at filler loadings equal or lower than 1.1 vol. \%. The CTE of HDPE and HDPE/ $\mathrm{A}_{2} \mathrm{M}_{3} \mathrm{O}_{12}$ composites is affected by the first 
heating cycle. However after the second heating cycle, the CTE is unchanged by the further heating runs. $\mathrm{Y}_{2} \mathrm{~W}_{3} \mathrm{O}_{12}$ acts more efficiently than $\mathrm{Al}_{2} \mathrm{~W}_{3} \mathrm{O}_{12}$ to decrease the CTEs of composites and to increase their Young's moduli, suggesting a more homogenous dispersion of $\mathrm{Y}_{2} \mathrm{~W}_{3} \mathrm{O}_{12}$ particles within the HDPE matrix. The CTE reduction caused by the incorporation of $\mathrm{Y}_{2} \mathrm{~W}_{3} \mathrm{O}_{12}$ into HDPE matrix was more significant (20 to $25 \%$ ) in the range between 25 to $70{ }^{\circ} \mathrm{C}$. For the highest filler content, the Young's modulus of composites increased up to 21 and $32 \%$ in the case of $\mathrm{Al}_{2} \mathrm{~W}_{3} \mathrm{O}_{12}$ and $\mathrm{Y}_{2} \mathrm{~W}_{3} \mathrm{O}_{12}$, respectively. Larger enhancement of crystallinity degree displayed by HDPE/ $\mathrm{Y}_{2} \mathrm{~W}_{3} \mathrm{O}_{12}$ composites could be responsible for greater improvements on mechanical and thermal expansion properties of these composites without deterioration of thermal stability of HDPE matrix. 


\section{7}

\section{Conclusions and future works}

Different co-precipitation methods to prepare $\mathrm{A}_{2} \mathrm{M}_{3} \mathrm{O}_{12}$ submicronic powders have been studied in this thesis for a better understanding of the fundamentals of these processes. Factors influencing the agglomeration state of $\mathrm{A}_{2} \mathrm{M}_{3} \mathrm{O}_{12}$ powders were also investigated because agglomeration can constrain the application of these compounds not only in the field of composite materials but also as engineering ceramics. Since $\mathrm{Y}_{2} \mathrm{~W}_{3} \mathrm{O}_{12}$ and $\mathrm{Al}_{2} \mathrm{~W}_{3} \mathrm{O}_{12}$ are ideal candidates to fulfill the role of fillers of HDPE-based composites, these compounds were synthesized in this work.

$\mathrm{Y}_{2} \mathrm{~W}_{3} \mathrm{O}_{12}$ was synthesized via co-precipitation by mixing reactants and modified reverse strike co-precipitation, to assess the effect of these methods on the agglomeration degree of powders.

- Both co-precipitation methods presented similar particle sizes and agglomeration degrees.

- The formation of oxyhydroxynitrate precursors, determined as $\mathrm{Y}_{2} \mathrm{~W}_{3} \mathrm{O}_{\mathrm{y}}(\mathrm{OH})_{\mathrm{z}}\left(\mathrm{NO}_{3}\right)_{\mathrm{x}} \cdot n \mathrm{H}_{2} \mathrm{O}$, can reduce the degree of agglomeration compared to hydroxyl ones.

- The applied calcination conditions caused the formation of necks between particles and hard agglomerates.

- The formation of $\mathrm{Y}_{2} \mathrm{~W}_{3} \mathrm{O}_{12}$ submicronic powders in the range of 0.60 to $0.70 \mu \mathrm{m}$ was verified by LD and FEG-SEM analyses.

$\mathrm{Al}_{2} \mathrm{~W}_{3} \mathrm{O}_{12}$ submicronic powders were synthesized via co-precipitation by mixing reactants and normal strike method, using two distinct tungsten sources. The effects of synthesis $\mathrm{pH}$ (4.2 and 6.0) on the final agglomeration state of the as-synthesized powders were assessed. 
- $\mathrm{Al}_{2} \mathrm{~W}_{3} \mathrm{O}_{12}$ submicronic powders ranging from 0.22 to $0.81 \mu \mathrm{m}$ were prepared via co-precipitation by mixing reactants and normal strike method, at synthesis $\mathrm{pH}=4.2$ and $\mathrm{pH}=6.0$ using microwave drying.

- For both co-precipitation methods, $\mathrm{pH}=6.0$ led to the formation of bigger agglomerates as demonstrated by $\mathrm{d}_{50}$ parameter, but composed of smaller primary particles.

- The co-precipitation method, dictated by the tungsten source, has a strong influence on the size of agglomerates, because it defines the crystallization and calcination temperatures.

- Co-precipitation by mixing reactants at $\mathrm{pH}=4.2$ was a more efficient method to produce $\mathrm{Al}_{2} \mathrm{~W}_{3} \mathrm{O}_{12}$ powders with the smallest agglomerate size $(\sim 0.22 \mu \mathrm{m})$.

HDPE-based composites filled with pristine $\mathrm{Al}_{2} \mathrm{~W}_{3} \mathrm{O}_{12}$ and $\mathrm{Y}_{2} \mathrm{~W}_{3} \mathrm{O}_{12}$ submicronic powders were manufactured by micro-compounding, using filler loadings of $0.1,0.3,0.6$ and 1.1 vol. \%.

- The CTE of HDPE and HDPE/ $\mathrm{A}_{2} \mathrm{M}_{3} \mathrm{O}_{12}$ composites is affected by the first heating cycle. However after the second heating cycle, the CTE is unchanged by the further heating runs.

- Both $\mathrm{Y}_{2} \mathrm{~W}_{3} \mathrm{O}_{12}$ and $\mathrm{Al}_{2} \mathrm{~W}_{3} \mathrm{O}_{12}$ fillers decrease the CTE of composites. The CTE reduction caused by the incorporation of $\mathrm{Y}_{2} \mathrm{~W}_{3} \mathrm{O}_{12}$ into HDPE matrix was more significant (20 to $25 \%$ ) in the range between 25 to $70{ }^{\circ} \mathrm{C}$.

- The filler content (between 0.1 and 1.1 vol. \%) does not have a strong influence on CTE of composites considering the standard deviations.

- The thermal stability of HDPE matrix is not affected by the addition of fillers. However, the fillers significantly increase the degree of crystallinity, especially in the case of $\mathrm{Y}_{2} \mathrm{~W}_{3} \mathrm{O}_{12}$.

- For the highest filler content, the Young's modulus of composites increased up to 21 and $32 \%$ in the case of $\mathrm{Al}_{2} \mathrm{~W}_{3} \mathrm{O}_{12}$ and $\mathrm{Y}_{2} \mathrm{~W}_{3} \mathrm{O}_{12}$, respectively.

Based on the results and conclusion arising from this thesis, suggestions for future work are presented as follows: 


\section{Synthesis of $\mathrm{Y}_{2} \mathrm{~W}_{3} \mathrm{O}_{12}$}

- Synthesis of $\mathrm{Y}_{2} \mathrm{~W}_{3} \mathrm{O}_{12}$ by modified reverse strike co-precipitation at constant $\mathrm{pH} 8$, keeping this $\mathrm{pH}$ in the desired value by addition of a solution of $\mathrm{NaOH}$, followed by ethanol washing and microwave drying in order to produce less agglomerated precursors.

- Study of calcination conditions of $\mathrm{Y}_{2} \mathrm{~W}_{3} \mathrm{O}_{12}$ precursor to reduce the formation of necks between particles and avoid the onset of sintering.

- Synthesis of $\mathrm{Y}_{2} \mathrm{~W}_{3} \mathrm{O}_{12}$ by hydrothermal treatment of the precursors obtained by co-precipitation in order to avoid the calcination step.

\section{Synthesis of $\mathrm{Al}_{2} \mathrm{~W}_{3} \mathrm{O}_{12}$}

- Synthesis of $\mathrm{Al}_{2} \mathrm{~W}_{3} \mathrm{O}_{12}$ at $\mathrm{pH}=6$ via co-precipitation by mixing reactants and normal-strike method using surfactants to prevent agglomeration during drying and calcination steps.

- FEG-SEM analysis of AlW-4.2-MW powder, which presented the smallest agglomerate size.

- Improving of calcination conditions to produce less agglomerated powders.

\section{HDPE-based composites filled with $\mathrm{Al}_{2} \mathrm{~W}_{3} \mathrm{O}_{12}$ and $\mathrm{Y}_{2} \mathrm{~W}_{3} \mathrm{O}_{12}$}

- SEM analysis of composites to gain insight into the dispersion state of $\mathrm{Al}_{2} \mathrm{~W}_{3} \mathrm{O}_{12}$ and $\mathrm{Y}_{2} \mathrm{~W}_{3} \mathrm{O}_{12}$ fillers.

- Manufacturing of HDPE-based composites filled with AlW-4.2-MW powder and assessment of CTE, mechanical and thermal properties of the as-prepared composites.

- Surface modification of $\mathrm{Al}_{2} \mathrm{~W}_{3} \mathrm{O}_{12}$ and $\mathrm{Y}_{2} \mathrm{~W}_{3} \mathrm{O}_{12}$ fillers with surfactants or silane coupling agents to improve wettability between fillers and HDPE matrix.

- Chemical modification of HDPE matrix with polyethylene-grafted maleic anhydride (PE-g-MA) to improve the compatibility between matrix and fillers.

- Study of the influence of thermal cycling on CTE, mechanical and thermal properties of HDPE/ $\mathrm{Y}_{2} \mathrm{~W}_{3} \mathrm{O}_{12}$ composites. 
8

\section{References}

[1] SOARES, A. R. et al. $\mathrm{Al}_{2} \mathrm{Mo}_{3} \mathrm{O}_{12} /$ polyethylene composites with reduced coefficient of thermal expansion. Journal of Materials Science, v. 49, n. 22, pp. 7870-7882, 2014.

[2] EVANS, J.; MARY, T.; SLEIGHT, A. Negative thermal expansion in a large molybdate and tungstate family. Journal of Solid State Chemistry, v. 275, n. 5296 , pp. 61-65, 1997.

[3] SLEIGHT, A. W.; BRIXNER, L. H. A new ferroelastic transition in some $\mathrm{A}_{2}\left(\mathrm{MO}_{4}\right)_{3}$ molybdates and tungstates. Journal of Solid State Chemistry, v. 7, n. 2, pp. 172-174, 1973.

[4] JARDIM, P. M.; GARCIA, E. S.; MARINKOVIC, B. A. Young's modulus, hardness and thermal expansion of sintered $\mathrm{Al}_{2} \mathrm{~W}_{3} \mathrm{O}_{12}$ with different porosity fractions. Ceramics International, v. 42, n. 4, pp. 5211-5217, 2016.

[5] FORSTER, P. M.; SLEIGHT, A. W. Negative thermal expansion in $\mathrm{Y}_{2} \mathrm{~W}_{3} \mathrm{O}_{12}$. International Journal of Inorganic Materials, v. 1, n. 2, pp. 123-127, 1999.

[6] WOODCOCK, D. A.; LIGHTFOOT, P.; RITTER, C. Negative thermal expansion in $\mathrm{Y}_{2}\left(\mathrm{WO}_{4}\right)_{3}$. Journal of Solid State Chemistry, v. 149, n. 1, p. 92-98, jan. 2000.

[7] ROMAO, C. P. et al. Negative thermal expansion (Thermomiotic) materials. Comprehensive Inorganic Chemistry II (Second Edition): From Elements to Applications, v. 4, pp. 127-151, 2013.

[8] MILLER, W. et al. Negative thermal expansion: A review. Journal of Materials Science, v. 44, n. 20, pp. 5441-5451, 2009.

[9] BARrerA, G. et al. Negative thermal expansion. J. Phys. Conden. Matt., v. 17, pp. R217-R252, 2005.

[10] MARINKOVIC, B. A. et al. Correlation between $\mathrm{AO}_{6}$ polyhedral distortion and negative thermal expansion in orthorhombic $\mathrm{Y}_{2} \mathrm{Mo}_{3} \mathrm{O}_{12}$ and 
related materials. Chemistry of Materials, v. 21, n. 13, pp. 2886-2894, 2009.

[11] LIND, C. Two decades of negative thermal expansion research: Where do we stand? Materials, v. 5, n. 6, pp. 1125-1154, 2012.

[12] SLEIGHT, A. W. Thermal contraction. Endeavour, v. 19, n. 2, pp. 6468, 1995.

[13] LIND, C. et al. G. R. Zirconium tungstate/polymer nanocomposites: Challenges and opportunities. Physica Status Solidi (B) Basic Research, v. 248, n. 1, pp. 123-129, 2011.

[14] EVANS, J. S. O. et al. A. W. Negative thermal expansion in $\mathrm{ZrW}_{2} \mathrm{O}_{8}$ and $\mathrm{HfW}_{2} \mathrm{O}_{8}$. Chemistry of Materials, v. 8, n. 12, pp. 2809-2823, 1996.

[15] EVANS, J.; MARY, T.; SLEIGHT, A. Negative thermal expansion in a large molybdate and tungstate family. Journal of Solid State Chemistry, v. 275 , n. 5296, pp. 61-65, 1997.

[16] ZHOU, Y. et al. Preparation and properties of carbonyl iron particles (CIPs)/silicone resin composite with negative thermal expansion filler. Journal of Polymer Research, v. 22, n. 7, pp. 138, 2015.

[17] PRISCO, L. P. et al. The effect of microstructure on thermal expansion coefficients in powder-processed $\mathrm{Al}_{2} \mathrm{Mo}_{3} \mathrm{O}_{12}$. Journal of Materials Science, v. 48, n. 7, pp. 2986-2996, 2013.

[18] HIGGINS, B.; GRAEVE, O. A.; EDWARDS, D. D. New methods for preparing submicrometer powders of the tungstate-ion conductor $\mathrm{Sc}_{2}\left(\mathrm{WO}_{4}\right)_{3}$ and its $\mathrm{Al}$ and In analogs. Journal of the American Ceramic Society, v. 96, n. 8, pp. 2402-2410, 2013.

[19] PRISCO, L. P. et al. Assessment of the thermal shock resistance figures of merit of $\mathrm{Al}_{2} \mathrm{~W}_{3} \mathrm{O}_{12}$, a low thermal expansion ceramic. Journal of the American Ceramic Society, v. 7, pp. 1-7, 2016.

[20] RU, Y. et al. Synthesis of yttrium aluminum garnet (YAG) powder by homogeneous precipitation combined with supercritical carbon dioxide or ethanol fluid drying. Journal of the European Ceramic Society, v. 28, n. 15, pp. 2903-2914, 2008.

[21] ZHECHEVA, E. et al. On the preparation of nanosized $\mathrm{Al}_{2}\left(\mathrm{WO}_{4}\right)_{3}$ by a precipitation method. Solid State Sciences, v. 12, n. 12, pp. 2010-2014, 
2010.

[22] KOSEVA, I. et al. Nanosized pure and $\mathrm{Cr}$ doped $\mathrm{Al}_{2-\mathrm{x}} \operatorname{In}\left(\mathrm{WO}_{4}\right)_{3}$ solid solutions. Materials Chemistry and Physics, v. 132, pp. 808-814, 2012.

[23] CHEN, H. I.; CHANG, H. Y. Homogeneous precipitation of cerium dioxide nanoparticles in alcohol/water mixed solvents. Colloids and Surfaces A: Physicochemical and Engineering Aspects, v. 242, n. 1-3, pp. 61-69, 2004.

[24] LOK, M. Co-precipitation sythesis. Solid Catalysis, In: JONG, K. P. (Ed.), Weinheim, Germany.: Wiley-VCH Verlag GmbH \& Co. KGaA, 2009. pp. 135.

[25] WEN, L. et al. Synthesis of yttria nanopowders for transparent yttria ceramics. Optical Materials, v. 29, n. 2-3, pp. 239-245, 2006.

[26] RAMANUJAM, P. et al. A comparative study of the synthesis of nanocrystalline Yttrium Aluminium Garnet using sol-gel and coprecipitation methods. Ceramics International, v. 40, n. 3, pp. 41794186, 2014.

[27] Ganguli, D.; CHATterjee, M. Ceramic Powder Preparation: A Handbook. 1st edition Ed. New York: Springer US, 1997.

[28] LOEHMAN, R. E. Characterization of Ceramics. New York: Momentum Press, LLC, 2010.

[29] RIEDEL, R.; CHEN, I.-W. Powder Characterization. In: RIEDEL, R.; CHEN, I.-W. (Eds.). Ceramics Science and Technology, Synthesis and Processing. Verlag: Wiley-VCH Verlag GmbH \& Co, 2012. pp. 339368.

[30] BOCH, P.; NIEPCE, J.-C. Ceramic materials: processes, properties, and applications. London: ISTE Ltd., 2001.

[31] MALVERN INSTRUMENTS LTD. A basic guide to particle characterization. Inform White Paper, pp. 1 - 26, 2012.

[32] PIERI, L.; BITTELLI, M.; PISA, P. R. Laser diffraction, transmission electron microscopy and image analysis to evaluate a bimodal Gaussian model for particle size distribution in soils. Geoderma, v. 135, pp. 118132, 2006.

[33] BOWEN, P. Particle size distribution measurement from millimeters to 
nanometers and from rods to platelets. Journal of Dispersion Science and Technology, v. 23, pp. 631-662, 2002.

[34] SCIENTIFIC, H. A Guidebook To Particle Size AnalysisDistribution, Irvine, 2016.

[35] KATO, H. et al. Accurate size and size-distribution determination of polystyrene latex nanoparticles in aqueous medium using dynamic light scattering and asymmetrical flow field flow fractionation with multi-angle light scattering. Nanomaterials, v. 2, n. 4, pp. 15-30, 2012.

[36] JIANG, J.; OBERDÖRSTER, G.; BISWAS, P. Characterization of size, surface charge, and agglomeration state of nanoparticle dispersions for toxicological studies. Journal of Nanoparticle Research, v. 11, n. 1, p. 77-89, 2009

[37] SCHÜTH, F.; HESSE, M.; UNGER, K. K. Precipitation and Coprecipitation. In: Handbook of Heterogeneous Catalysis. Wiley-VCH Verlag GmbH \& Co. KGaA., 2008. pp. 100-119

[38] HAN, X. et al. Co-precipitated synthesis of $\mathrm{Al}_{2} \mathrm{O}_{3}-\mathrm{ZrO}_{2}$ composite ceramic nanopowders by precipitant and drying method regulation: A systematic study. Ceramics International, v. 41, n. 1, pp. 505-513, 2014.

[39] LI, J. G. et al. Co-precipitation synthesis and sintering of yttrium aluminum garnet (YAG) powders: The effect of precipitant. Journal of the European Ceramic Society, v. 20, n. 14-15, pp. 2395-2405, 2000.

[40] KALISZEWSKI, M. S.; HEUER, A. H. Alcohol interaction with zirconia powders.pdf. Journal of American Ceramics Society, v. 73, n. 6, pp. 1504-1509, 1990.

[41] MASKARA, A.; SMITH, D. Agglomeration during the drying of fine silica powders, part II: The role of particle solubility. Journal of the American Ceramic Society, pp. 1715-1722, 1997.

[42] WANG, B. et al. Progress in Drying Technology for Nanomaterials. Drying Technology, v. 23, n. 1-2, pp. 7-32, 2005.

[43] KRALCHEVSKY, P. A.; DENKOV, N. D. Capillary forces and structuring in layers of colloid particles. Current Opinion in Colloid and Interface Science, v. 6, n. 4, pp. 383-401, 2001. 
[44] YU, J.; WANG, G.; CHENG, B. Effects of microwave drying on the microstructure and photocatalytic activity of bimodal mesoporous $\mathrm{TiO}_{2}$ powders. Journal of Physics and Chemistry of Solids, v. 71, n. 4, pp. 523-526, 2010.

[45] METZGER, T. et al. Understanding and preventing structural changes during drying of gels. Modern Drying Technology, v. 3-4, pp. 155-229, 2014.

[46] LIAPIS, A. I.; BRUTTINI, R. Handbook of industrial drying. Boca Raton: Taylor \& Francis Group, 2006.

[47] GONG, H.; TANG, D. Y.; HUANG, H.; MA, J. Agglomeration control of $\mathrm{Nd}$ :YAG nanoparticles via freeze drying for transparent $\mathrm{Nd}: \mathrm{YAG}$ ceramics. Journal of the American Ceramic Society, v. 92, n. 4, pp. 812-817, 2009.

[48] WANG, C. L. et al. Formation and morphology of $\mathrm{Zn}_{2} \mathrm{Ti}_{3} \mathrm{O}_{8}$ powders using hydrothermal process without dispersant agent or mineralizer. International Journal of Molecular Sciences, v. 12, n. 2, pp. 935-945, 2011.

[49] CHEN, Z.; LAMB, F. M. Analysis of the vacuum drying rate for red oak in a hot water vacuum drying system. Drying Technology, v. 25, n. 3, pp. 497-500, 2007.

[50] TAKE, W. A. et al. Thermal expansion and contraction of geomembrane liners subjected to solar exposure and back filling. Journal of Geotechnical and Geoenvironmental Engieering, v. 1, n. November, pp. 1387-1397, 2012.

[51] MERAH, N. et al. Effect of temperature on tensile properties of HDPE pipe material. Plastics, Rubber and Composites, v. 35, n. 5, pp. 226230, 2006

[52] YANG, P. et al. Test on effect of temperature on area of thermal expansion of HDPE Geomembrane.pdf. In: Engineering Geology for Society and Territory. Switzerland: Springer International Publishing, 2014. pp. 121-124.

[53] SHI, J. D. et al. Composite materials with adjustable thermal expansion for electronic applications. MRS Proceedings, v. 445, pp. 229-234, 
1996.

[54] SUlliVAN, L. M.; LUKEHART, C. M. Zirconium tungstate $\left(\mathrm{ZrW}_{2} \mathrm{O}_{8}\right) /$ polyimide nanocomposites exhibiting reduced coefficient of thermal expansion. Chemistry of Materials, v. 17, n. 8, pp. 2136-2141, 2005 .

[55] GUO, C.; ZHOU, L.; LV, J. Effects of expandable graphite and modified ammonium polyphosphate on the flame-retardant and mechanical properties of wood flour-polypropylene composites. Polymers and Polymer Composites, v. 21, n. 7, pp. 449-456, 2013.

[56] CHU, X. et al. The cryogenic thermal expansion and mechanical properties of plasma modified $\mathrm{ZrW}_{2} \mathrm{O}_{8}$ reinforced epoxy. Materials Science and Engineering A, v. 528, n. 9, pp. 3367-3374, 2011.

[57] SHARMA, G. R.; LIND, C.; COLEMAN, M. R. Preparation and properties of polyimide nanocomposites with negative thermal expansion nanoparticle filler. Materials Chemistry and Physics, v. 137, n. 2, pp. 448-457, 2012.

[58] AKULICHEV, A. G. et al. Thermomechanical properties of zirconium tungstate/hydrogenated nitrile butadiene rubber (HNBR) composites for low-temperature applications. Journal of Materials Science, v. 51, n. 24, pp. 10714-10726, 2016.

[59] IMANAKA, $\mathrm{N}$. et al. Thermal contraction behavior in $\mathrm{Al}_{2}\left(\mathrm{WO}_{4}\right)_{3}$ single crystal. Journal of Crystal Growth, v. 220, pp. 176-179, 2000.

[60] FORSTER, P. M.; YOKOCHI, A.; SLEIGHT, A. W. Enhanced negative thermal expansion in $\mathrm{Lu}_{2} \mathrm{~W}_{3} \mathrm{O}_{12}$. Journal of Solid State Chemistry, v. 158, n. 140, pp. 157-158, 1998.

[61] SUMITHRA, S.; UMARJ, A. M. Hygroscopicity and bulk thermal expansion in $\mathrm{Y}_{2} \mathrm{~W}_{3} \mathrm{O}_{12}$. Materials Research Bulletin, v. 40, n. 1, pp. 167-176, 2005.

[62] MARINKOVIC, B. A. et al. Negative thermal expansion in $\mathrm{Y}_{2} \mathrm{Mo}_{3} \mathrm{O}_{12}$. Solid State Sciences, v. 7, n. 11, pp. 1377-1383, 2005.

[63] MARINKOVIC, B. A. et al. Correlation between AO6 polyhedral distortion and negative thermal expansion in orthorhombic $\mathrm{Y}_{2} \mathrm{Mo}_{3} \mathrm{O}_{12}$ and related materials. Chemistry of Materials, v. 21, n. 13, pp. 2886-2894, 
2009.

[64] YOON, P. J.; FORNES, T. D.; PAUL, D. R. Thermal expansion behavior of nylon 6 nanocomposites. Polymer, v. 43, n. 25, pp. 6727-6741, 2002.

[65] TURNER, P. S. Thermal-expansion stresses in reinforced plastics. Journal of Research of the National Bureau of Standards, v. 37, n. 4, p. 239, 1946.

[66] SCHAPERY, R. A. Thermal expansion coefficients of composite materials based on energy principles. Journal of Composite Materials, v. 2, pp. 380-404, 1968.

[67] HASHIN, Z.; SHTRIKMAN, S. A variational approach to the theory of the elastic behaviour of multiphase materials. Journal of the Mechanics and Physics of Solids, v. 11, n. 2, pp. 127-140, 1963.

[68] TAKENAKA, K. Negative thermal expansion materials: technological key for control of thermal expansion. Science and Technology of Advanced Materials, v. 13, n. 1, pp. 013001, 2012.

[69] YANASE, I.; MIYAGI, M.; KOBAYASHI, H. Fabrication of zerothermal-expansion $\mathrm{ZrSiO}_{4} / \mathrm{Y}_{2} \mathrm{~W}_{3} \mathrm{O}_{12}$ sintered body. Journal of the European Ceramic Society, v. 29, n. 15, pp. 3129-3134, 2009.

[70] DAS, S; DAS, K, Synthesis and thermal behavior of $\mathrm{Cu} / \mathrm{Y}_{2} \mathrm{~W}_{3} \mathrm{O}_{12}$ composite. Ceramics International, v. 40, n. 5, pp. 6465-6472, 2014.

[71] DAS, S.; DAS, S.; DAS, K. Low temperature synthesis of negative thermal expansion $\mathrm{Y}_{2} \mathrm{~W}_{3} \mathrm{O}_{12}$. Journal of Materials Engineering and Performance, v. 22, n. 11, pp. 3357-3363, 2013.

[72] XU, L.; SHEN, J.; LU, C.; HOU, W. Self-Assembled three-dimensional architectures of $\mathrm{Y}_{2}\left(\mathrm{WO}_{4}\right)_{3}$ : Eu: Controlled synthesis, growth mechanism, and shape-dependent luminiscence properties. Crystal Growth \& Design, v. 9, n.7, pp. 3129-3136, 2009.

[73] HUANG, S. et al. Controllable synthesis and tunable luminescence properties of $\mathrm{Y}_{2}\left(\mathrm{WO}_{4}\right)_{3}: \operatorname{Ln}^{3+}(\mathrm{Ln}=\mathrm{Eu}, \mathrm{Yb} / \mathrm{Er}, \mathrm{Yb} / \mathrm{Tm}$ and $\mathrm{Yb} / \mathrm{Ho}) 3 \mathrm{D}$ hierarchical architectures. Dalton Transactions, v. 41, n. 18, pp. 5634, 2012.

[74] HASSANZADEH-TABRIZI, S. A.; TAHERI-NASSAJ, E. Synthesis of high surface area $\mathrm{Al}_{2} \mathrm{O}_{3}-\mathrm{CeO}_{2}$ composite nanopowder via inverse co- 
precipitation method. Ceramics International, v. 37, n. 4, p. 1251-1257, 2011.

[75] LIU, X.; LU, X.; WANG，R.; ZHOU，H. First-principles molecular dynamics study of stepwise hydrolysis reactions of $\mathrm{Y}^{3+}$ cations. Chemical Geology, v. 334, pp. 37-43, 2012.

[76] RUDOLPH, W. W.; IRMER, G. Hydration and ion pair formation in common aqueous $\mathrm{Y}^{3+}$-salt solutions. Dalton Trans., v. 44, n. 1, pp. 295$305,2015$.

[77] DAVANTES, A.; COSTA, D.; LEFEVRE, G. Infrared study of (poly)tungstate ions in solution and sorbed into layered double hydroxides: vibrational calculations and in situ analysis. Journal of Physical Chemistry C, v. 119, n. 22, pp. 12356-12364, 2015.

[78] FAN, L.; CAO, J.; HU, C. What can electrospray mass spectrometry of paratungstates in an equilibrating mixture tell us? Royal Society of

Chemistry Advances, v. 5, n. 101, pp. 83377-83382, 2015.

[79] FOKEMA, M. D.; CHIU, E.; YING, J. Y. Synthesis and characterization of nanocrystalline yttrium oxide prepared with tetraalkylammonium hydroxides. Langmuir, v. 16, n. 7, pp. 3154-3159, 2000.

[80] SLEIGHT, A. W. Negative Thermal Expansion. MRS Proceedings, v. 755, n. July, p. 17-29, 2003.

[81] KOL'TSOVA, T. X-ray Diffraction Study of $\mathrm{Y}_{2} \mathrm{~W}_{3} \mathrm{O}_{12} \cdot 3 \mathrm{H}_{2} \mathrm{O}$. Inorganic Materials, v. 37, n. 11, pp. 1175-1177, 2001.

[82] KOH, J.-H. et al. Thermal expansion behaviors of yttrium tungstates in the $\mathrm{WO}_{3}-\mathrm{Y}_{2} \mathrm{O}_{3}$ system. Ceramics International, v. 39, n. 7, pp. 84218427, 2013.

[83] NIKOLOV, V. et al. Conditions for preparation of nanosized $\mathrm{Al}_{2}\left(\mathrm{WO}_{4}\right)_{3}$. Journal of Alloys and Compounds, v. 505, n. 2, pp. 443-449, 2010.

[84] PONTÓN, P. I. et al. Co-precipitation synthesis of $\mathrm{Y}_{2} \mathrm{~W}_{3} \mathrm{O}_{12}$ submicronic powder. Ceramics International, v. 43, n.5, pp. 4222-4228, 2016.

[85] LI, J. et al. Co-precipitation synthesis route to yttrium aluminum garnet (YAG) transparent ceramics. Journal of the European Ceramic Society, v. 32, n. 11, pp. 2971-2979, 2012.

[86] VROLIJK, J. W. et al. Coprecipitation of yttrium and aluminium 
hydroxide for preparation of yttrium aluminium garnet. Journal of the European Ceramic Society, v. 6, n. 1, pp. 47-51, 1990.

[87] APTE, P.; BURKE, H.; PICKUP, H. Synthesis of yttrium aluminum garnet by reverse strike precipitation. Journal of Materials Research, v. 7, n. 03, pp. 706-711, 1992.

[88] MARLOT, C. et al. Synthesis of YAG nanopowder by the coprecipitation method: Influence of $\mathrm{pH}$ and study of the reaction mechanisms. Journal of Solid State Chemistry, v. 191, pp. 114-120, 2012.

[89] LI, J.-G. et al. Well sinterable $\mathrm{Y}_{3} \mathrm{Al}_{5} \mathrm{O}_{12}$ powder from carbonate precursor. Journal of Materials Research, v. 15, n. 7, pp. 1514-1523, 2000.

[90] TEL'NOVA, G. B. et al. Effect of carbonate precursor synthesis conditions on the formation of monodisperse Nd:YAG nanopowders. Inorganic Materials, v. 51, n. 2, pp. 142-151, 2015.

[91] EL-MASRY, M. H.; SADEK, O. M.; MEKHEMER, W. K. Purification of raw surface water using electro-coagulation method. Water, Air, and Soil Pollution, v. 158, n. 1, p. 373-385, 2004.

[92] HE, T.; XIANG, L.; ZHU, S. Different nanostructures of boehmite fabricated by hydrothermal process: effects of $\mathrm{pH}$ and anions. CrystEngComm, v. 11, n. 7, p. 1338, 2009.

[93] LEBRUN, G.; DENAULT, J. Effect of annealing on the thermal expansion and residual stresses of bidirectional thermoplastic composite laminates. Composites Part A: Applied Science and Manufacturing, v. 41, n. 1, pp. 101-107, 2010.

[94] MARTIENSSEN, W.; WARLINGMONT, H. Handbook of Condensed Matter and Materials Data. New York, Springer, 2005.

[95] GOERTZEN, W. K.; KESSLER, M. R. Three-phase cyanate ester composites with fumed silica and negative-CTE reinforcements. Journal of Thermal Analysis and Calorimetry, v. 93, n. 1, pp 87-93, 2008.

[96] ROMAO, C. P. Thermoelastic properties of materials with negative coefficients of thermal expansion, Halifax, Nova Scotia: Doctoral thesis, 2015.

[97] ROMAO, C. P. et al. Thermal, vibrational, and thermoelastic properties of 
$\mathrm{Y}_{2} \mathrm{Mo}_{3} \mathrm{O}_{12}$ and their relations to negative thermal expansion. Physical Review B, v. 90, n. 2, pp. 024305, 2014.

[98] VARGA, T. et al. High pressure synchrotron x-ray powder diffraction study of $\mathrm{Sc}_{2} \mathrm{Mo}_{3} \mathrm{O}_{12}$ and $\mathrm{Al}_{2} \mathrm{~W}_{3} \mathrm{O}_{12}$. Journal of Physics: Condensed Matter, v. 17, n. 27, pp. 4271-4283, 2005.

[99] Karmakar VROLIJK, J. W. G. A.; WILlEMS, J. W. M. M.; METSELAAR, R. Coprecipitation of yttrium and aluminium hydroxide for preparation of yttrium aluminium garnet. Journal of the European Ceramic Society, v. 6, n. 1, pp. 47-51, 1990.

[100] WUNDERLICH, B. Thermal analysis of polymer materials. San Diego: Academic Press, 1990. 


\section{Appendix $A^{2}$ : Supplementary material to support Chapter 4}

\section{A.1. \\ Chemical composition of $\mathrm{Y}_{2} \mathrm{~W}_{3} \mathrm{O}_{12}$ precursors}

Three hypothetical formulae of $\mathrm{Y}_{2} \mathrm{~W}_{3} \mathrm{O}_{12}$ amorphous precursors were suggested and assessed. The formulae were built bearing in mind the likely ionic species that could be part of a hydroxynitrate or oxyhydroxynitrate precursor:

\section{A.1.1.}

\section{First hypothetical formula: $\mathrm{Y}_{2}(\mathrm{OH})_{z}\left(\mathrm{NO}_{3}\right)_{x}\left(\mathrm{WO}_{4}\right)_{\mathrm{u}} \cdot n \mathrm{H}_{2} \mathrm{O}$}

This formula was proposed assuming that $\mathrm{Y}^{3+}$ might form a complex with $(\mathrm{OH})^{-},\left(\mathrm{NO}_{3}\right)^{-}$and water molecules, while $\mathrm{W}^{6+}$ exists in the form of $\left(\mathrm{WO}_{4}\right)^{2-}$ monomeric species [84].

The following equation can be written considering the charge neutrality of the proposed compound:

$$
\begin{gathered}
2(+3)+z(-1)+x(-1)+u(-2)=0 \\
x+z+2 u=6
\end{gathered}
$$

However, the subscript of $\mathrm{W}^{6+}$ should be 3 to be in accordance with the final chemical formula of yttrium tungstate $\left(\mathrm{Y}_{2} \mathrm{~W}_{3} \mathrm{O}_{12}\right)$. Thus, replacing $u=3$ in Equation (A1):

$$
x+z+2(3)=6
$$

Therefore,

$$
x+z=0
$$

This is not possible, because $x$ and $z$ must be positive numbers.

${ }^{2}$ This appendix was adapted from P.I. Pontón, L.P. Prisco, A. Dosen, G.S. Faro, M.A.S. de Abreu, B.A. Marinkovic, Co-precipitation synthesis of $\mathrm{Y}_{2} \mathrm{~W}_{3} \mathrm{O}_{12}$ submicronic powder, Ceram. Int. (2017) 43, 5, 4222-4228 (Supplementary Information Material) [84]. 


\section{A.1.2.}

\section{Second hypothetical formula: $\mathrm{Y}_{2} \mathrm{~W}_{3}(\mathrm{OH})_{2}\left(\mathrm{NO}_{3}\right)_{x} \cdot n \mathrm{H}_{2} \mathrm{O}$}

This formula was suggested considering that $\mathrm{Y}^{3+}$ might be part of a complex with $(\mathrm{OH})^{-},\left(\mathrm{NO}_{3}\right)^{-}$and water molecules, while $\mathrm{W}^{6+}$ is present in the precipitate in its cationic form [84].

Taking into account the charge neutrality of the compound and considering that the oxidation state of $\mathrm{W}$ in the precursor is +6 and maintained during all the stages of thermal treatment up to the crystallization of $\mathrm{Y}_{2} \mathrm{~W}_{3} \mathrm{O}_{12}$ phase, the following equation can be written:

$$
\begin{gathered}
2(+3)+3(+6)+z(-1)+x(-1)=0 \\
z=24-x
\end{gathered}
$$

From TG curves of the precursors (see Figure A.1), the mass losses can be calculated in different temperature ranges and are shown in Table A. 1.

(b)
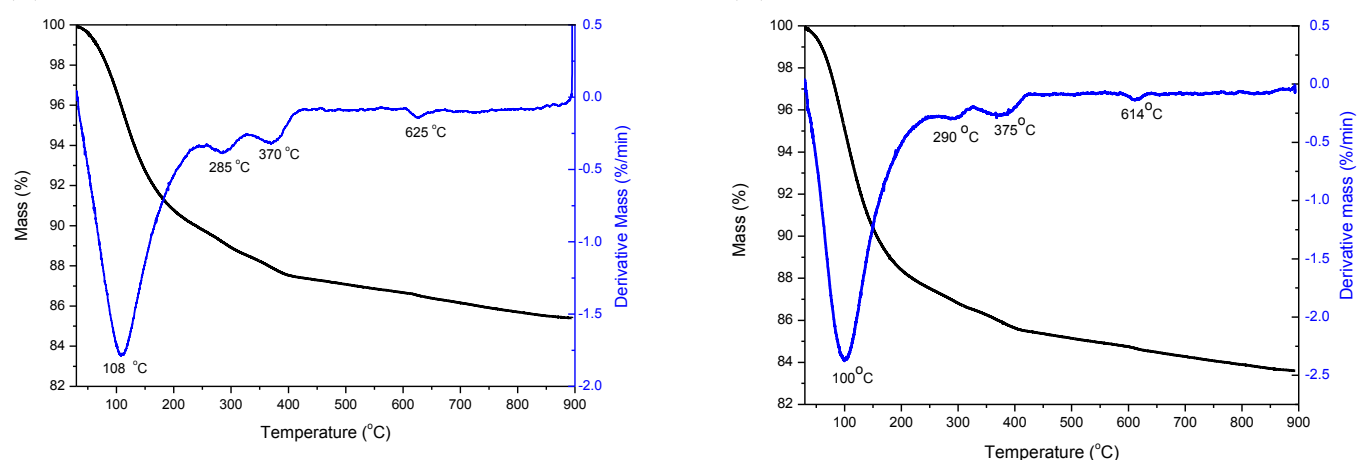

Figure A.1- TG and DTG curves of (a) $\mathrm{pY}_{2} \mathrm{~W}_{3} \mathrm{O}_{12}-\mathrm{A}$ and (b) $\mathrm{pY}_{2} \mathrm{~W}_{3} \mathrm{O}_{12}-\mathrm{B}$ [84].

Table A. 1- Mass losses of $\mathrm{Y}_{2} \mathrm{~W}_{3} \mathrm{O}_{12}$ precursors [84].

\begin{tabular}{ccc}
\cline { 2 - 3 } & \multicolumn{2}{c}{ Mass loss $(\%)$} \\
\hline $\begin{array}{c}\text { Temperature } \\
\text { range }\left({ }^{\circ} \mathbf{C}\right)\end{array}$ & $\mathbf{p Y}_{\mathbf{2}} \mathbf{W}_{\mathbf{3}} \mathbf{O}_{\mathbf{1 2}}-\mathbf{A}$ & $\mathbf{p Y}_{\mathbf{2}} \mathbf{W}_{\mathbf{3}} \mathbf{O}_{\mathbf{1 2}}-\mathbf{B}$ \\
\hline $30-150$ & 7.264 & 9.612 \\
$150-250$ & 2.933 & 2.870 \\
$250-300$ & 0.890 & 0.702 \\
$300-400$ & 1.377 & 1.181 \\
$400-650$ & 1.146 & 1.152 \\
$650-900$ & 0.986 & 0.880 \\
$150-900$ & 7.332 & 6.785 \\
$30-900$ & 14.596 & 16.397 \\
\hline
\end{tabular}


Hence, the total mass losses of $\mathrm{pY}_{2} \mathrm{~W}_{3} \mathrm{O}_{12}-\mathrm{A}$ and $\mathrm{pY}_{2} \mathrm{~W}_{3} \mathrm{O}_{12}-\mathrm{B}$ are 14.596 and $16.397 \%$, respectively. Since the total mass loss of each precursor is attributed to the release of water molecules and the decomposition of nitrate ions and hydroxyl groups in such a way that the number of oxygen atoms should be the same of the chemical formula of $\mathrm{Y}_{2} \mathrm{~W}_{3} \mathrm{O}_{12}$, the remaining mass at the end of thermogravimetric analysis should correspond merely to the molecular weight of crystalline $\mathrm{Y}_{2} \mathrm{~W}_{3} \mathrm{O}_{12}$ compound $\left(m_{Y_{2} W_{3} O_{12}}=921.33 \mathrm{~g} / \mathrm{mol}\right)$. Therefore, for $\mathrm{pY}_{2} \mathrm{~W}_{3} \mathrm{O}_{12}-\mathrm{A}$ :

$$
m_{Y_{2} W_{3} O_{12}}=(1-0.14596) m_{T}=921.33 \mathrm{~g} / \mathrm{mol}
$$

where $m_{T}$ is the total mass of the precursor (molecular weight of the precursor). Solving Equation (A3), $m_{T}=1078.79 \mathrm{~g} / \mathrm{mol}$.

The subscript $x$ can be computed based on the mass percentage of nitrogen $\left(p_{N}\right)$, which can be expressed as a function of $m_{T}$ using the following equation:

$$
p_{N}=\frac{x\left(m_{N}\right)}{m_{T}} x 100
$$

where, $m_{N}$ is the atomic weight of nitrogen and $p_{N}=0.8$ mass $\%$ (see Table 1 in main article). Accordingly, $x=0.62$ and replacing this value in Equation (A2), $z=23.38$

Since the mass loss of absorbed water molecules (dehydration process) normally occurs up to $150{ }^{\circ} \mathrm{C}$, the number of water molecules $(n)$ can be estimated from this value. In the case of $\mathrm{pY}_{2} \mathrm{~W}_{3} \mathrm{O}_{12}$-A this mass loss corresponds to 7.264 mass \% (See Table A. 1). Thus, the following equation can be written:

$$
n m_{\mathrm{H}_{2} \mathrm{O}}=0.07264 m_{T}
$$

where, $m_{\mathrm{H}_{2} \mathrm{O}}$ is the molecular weight of water. Replacing $m_{\mathrm{H}_{2} \mathrm{O}}$ and $m_{T}$ value in Equation (A5), $n=4.35$. Therefore, the chemical formula of $\mathrm{pY}_{2} \mathrm{~W}_{3} \mathrm{O}_{12^{-}}$ A would be: $\mathrm{Y}_{2} \mathrm{~W}_{3}(\mathrm{OH})_{23.38}\left(\mathrm{NO}_{3}\right)_{0.62 \cdot 4.35 \mathrm{H}_{2}} \mathrm{O}$.

In order to verify the validity of this formula, it is possible to calculate the molecular weight of the precursor from the following equation and it should be equal to the previously computed $\mathrm{m}_{\mathrm{T}}$ value:

$$
m_{T}=2 m_{Y}+3 m_{W}+z m_{O H}+x m_{N_{3}}+n m_{H_{2} O}
$$

where $m_{Y}$ and $m_{W}$ are the atomic weights of yttrium and tungstate, respectively, while $m_{\mathrm{OH}}$ and $m_{\mathrm{NO}_{3}}$ are the molecular weights of hydroxyl and nitrate groups. 
However, the molecular weight of the $\mathrm{pY}_{2} \mathrm{~W}_{3} \mathrm{O}_{12}$-A calculated from Equation (A6) is $1243.53 \mathrm{~g} / \mathrm{mol}$, which is much higher than the $m_{T}$ value computed before. Therefore, this formula is wrong. Finally, considering the hydrogen mass percentage obtained from CHN ( $p_{H}=1.4$ mass $\left.\%\right)$ and the computed one from the proposed chemical formula $\left(p_{H}=2.58\right.$ mass $\left.\%\right)$, it is possible to verify again that the second hypothetical formula is not correct.

\section{A.1.3.}

\section{Third hypothetical formula: $\mathrm{Y}_{2} \mathrm{~W}_{3} \mathrm{O}_{\mathrm{y}}(\mathrm{OH})_{\mathrm{z}}\left(\mathrm{NO}_{3}\right)_{\mathrm{x}} \cdot \mathrm{nH}_{2} \mathrm{O}$}

This formula was proposed assuming that $\mathrm{Y}^{3+}$ might form a complex with $(\mathrm{OH})^{-},\left(\mathrm{NO}_{3}\right)^{-}$and water molecules, while $\mathrm{W}^{6+}$ is present in the form of $\left(\mathrm{W}_{3} \mathrm{O}_{\mathrm{y}}\right)^{18-}$ ${ }^{2 y}$ polytungstate species [84].

The next equation can be written from the charge neutrality of the compound:

$$
\begin{gathered}
2(+3)+3(+6)+y(-2)+z(-1)+x(-1)=0 \\
z=24-2 y-x
\end{gathered}
$$

Using the previously computed $m_{T}=1078.79 \mathrm{~g} / \mathrm{mol}$ for $\mathrm{pY}_{2} \mathrm{~W}_{3} \mathrm{O}_{12}-\mathrm{A}$ and the Equations (A4) and (A5) already deduced:

$$
\begin{aligned}
& x=0.62 \\
& n=4.35
\end{aligned}
$$

On the other hand, $m_{T}$ can be calculated from the proposed chemical formula as follows:

$$
m_{T}=2 m_{Y}+3 m_{W}+y m_{o}+z m_{O H}+x m_{N_{3}}+n m_{H_{2} O}
$$

where, $m_{o}$ is the atomic weight of oxygen.

If Equation (A7) is replaced in Equation (A8):

$$
m_{T}=2 m_{Y}+3 m_{W}+y m_{o}+(24-2 y-x) m_{O H}+x m_{N_{3}}+n m_{H_{2} O}
$$

Since $y$ is the only value unknown in Equation (A9), it can be easily calculated as follows:

$$
y=\frac{1137.332-0.90165 m_{T}}{18}
$$




$$
y=9.15
$$

Finally, $z$ value can be computed by replacing $x$ and $y$ values in Eq. (A7):

$$
z=5.08
$$

As a result, the chemical formula of $\mathrm{pY}_{2} \mathrm{~W}_{3} \mathrm{O}_{12}-\mathrm{A}$ is $\mathrm{Y}_{2} \mathrm{~W}_{3} \mathrm{O}_{9.15}(\mathrm{OH})_{5.08}\left(\mathrm{NO}_{3}\right)_{\mathbf{0 . 6 2}} \mathbf{4 . 3 5}_{2} \mathrm{O}$ and it matches with the molecular weight of the precursor $\left(m_{T}=1078.79 \mathrm{~g} / \mathrm{mol}\right)$. Besides, considering the hydrogen mass percentage obtained from $\mathrm{CHN}\left(p_{H}=1.4\right.$ mass $\left.\%\right)$ and the calculated one from the proposed chemical formula $\left(p_{H}=1.3\right.$ mass $\left.\%\right)$ ), it is possible to confirm that the third hypothetical formula is correct. Based on the same approach the chemical formula of $\mathrm{pY}_{2} \mathrm{~W}_{3} \mathrm{O}_{12}-\mathrm{B}$ is $\mathbf{Y}_{\mathbf{2}} \mathbf{W}_{\mathbf{3}} \mathrm{O}_{\mathbf{9 . 4 2}}(\mathbf{O H})_{\mathbf{4 . 5 3}}\left(\mathrm{NO}_{\mathbf{3}}\right)_{\mathbf{0 . 6 2} .5 .88 \mathrm{H}_{2}} \mathrm{O}$.

\section{A.2.}

\section{Speciation diagrams of $\mathrm{Y}^{3+}$ and $\mathrm{W}^{6+}$}

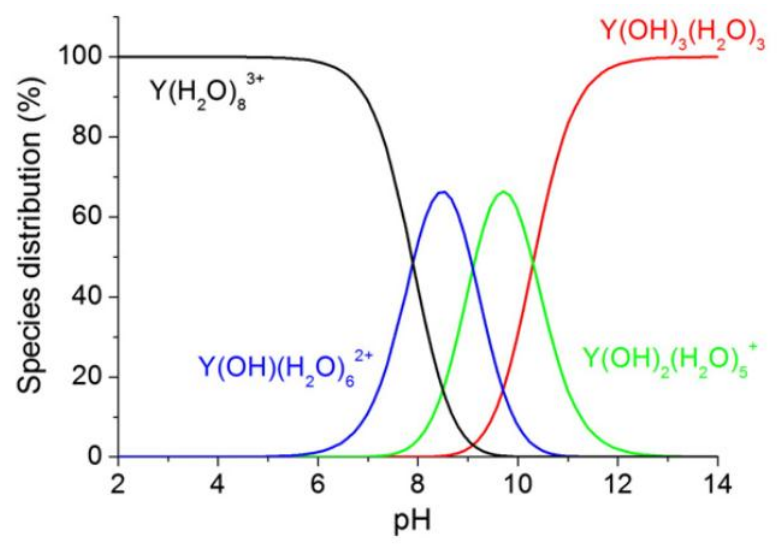

Figure A.2- Speciation diagram of $\mathrm{Y}^{3+}[75]$. 


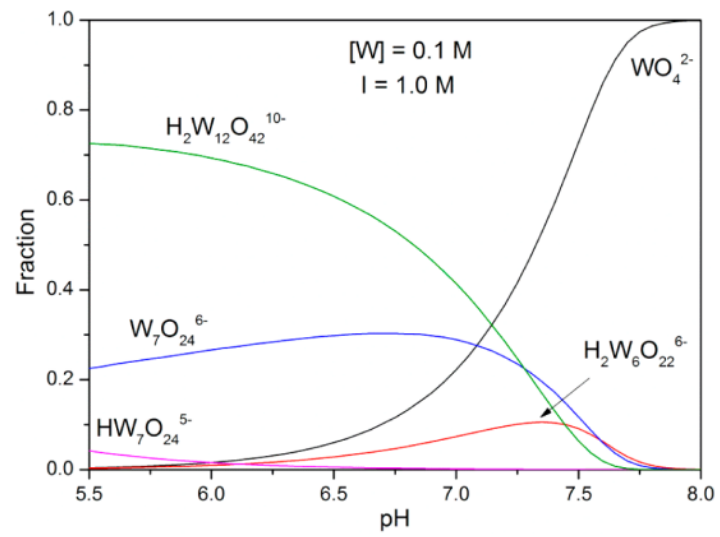

Figure A.3- Speciation diagram of $\mathrm{W}^{6+}$ from a $0.1 \mathrm{M}$ Na2WO4 solution [77].

A.3.

Thermogravimetric analysis of $\mathrm{Y}_{2} \mathrm{~W}_{3} \mathrm{O}_{12}$ as-synthesized powders

(a)

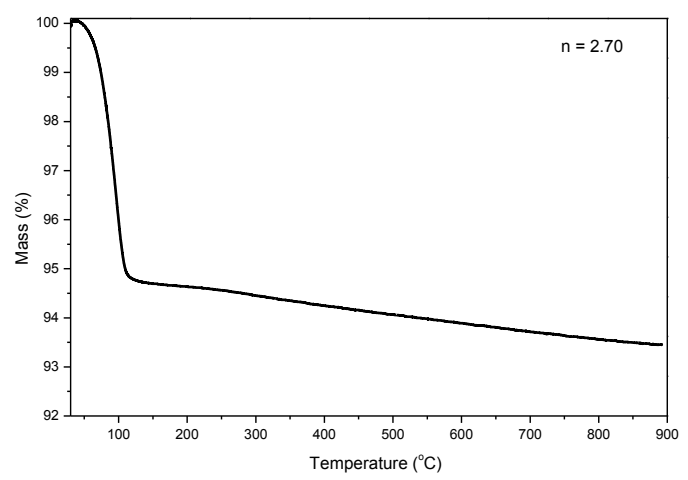

(b)

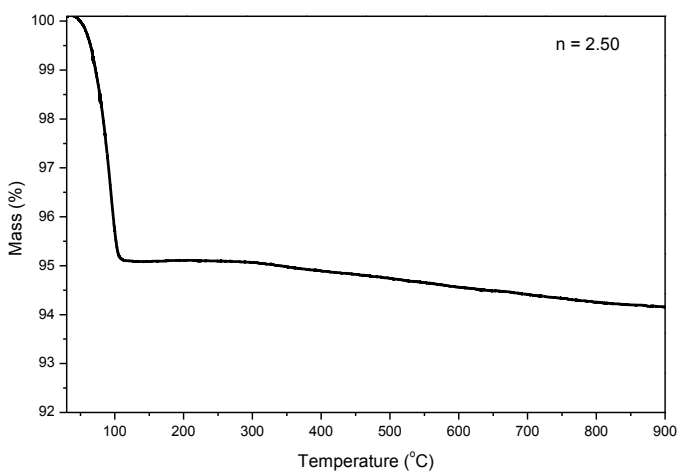

Figure A.4- TG curves of hydrated crystalline samples of (a) $\mathrm{Y}_{2} \mathrm{~W}_{3} \mathrm{O}_{12}-\mathrm{A} \cdot 2.70 \mathrm{H}_{2} \mathrm{O}$ and (b) $\mathrm{Y}_{2} \mathrm{~W}_{3} \mathrm{O}_{12}-\mathrm{B} \cdot 2.50 \mathrm{H}_{2} \mathrm{O}[84]$.

A.4.

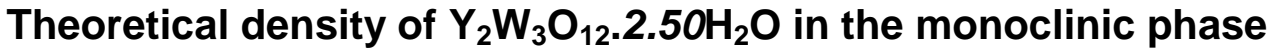

The theoretical density of $\mathrm{Y}_{2} \mathrm{~W}_{3} \mathrm{O}_{12} \cdot 2.50 \mathrm{H}_{2} \mathrm{O}$ in the monoclinic phase can be calculated using the following equation [84]:

$$
\rho=\frac{n M}{V N_{A}}
$$

where:

$n$ is the number of chemical formulae associated to monoclinic unit cell within $\mathrm{P} 2 / \mathrm{m}$ space group $=8$ 
$M=$ molecular weight of $\mathrm{Y}_{2} \mathrm{~W}_{3} \mathrm{O}_{12} \cdot 2 \cdot 50 \mathrm{H}_{2} \mathrm{O}=966.332 \mathrm{~g} / \mathrm{mol}$

$N_{a}=$ Avogadro's number

$V=$ Volume of unit cell $=2579.85 \AA$

Thus, the theoretical density of $\mathrm{Y}_{2} \mathrm{~W}_{3} \mathrm{O}_{12} \cdot 2.50 \mathrm{H}_{2} \mathrm{O}$ in the monoclinic phase is $4.976 \mathrm{gcm}^{-3}$, as follows:

$$
\begin{gathered}
\rho=\frac{8 \frac{\text { sites }}{\text { unit cell }}\left(966.332 \frac{\mathrm{g}}{\mathrm{mol}}\right)}{2579.85 \times 10^{-30} \frac{\mathrm{m}^{3}}{\text { unit cell }} \frac{\left(6.022 \times 10^{23} \text { atoms ou sites }\right)}{1 \mathrm{~mol}} \frac{\left(10^{6}\right) \mathrm{cm}^{3}}{1 \mathrm{~m}^{3}}} \\
\rho=4.976 \frac{\mathrm{g}}{\mathrm{cm}^{3}}
\end{gathered}
$$




\section{Appendix B: Supplementary material to support Chapter 5}

(a)

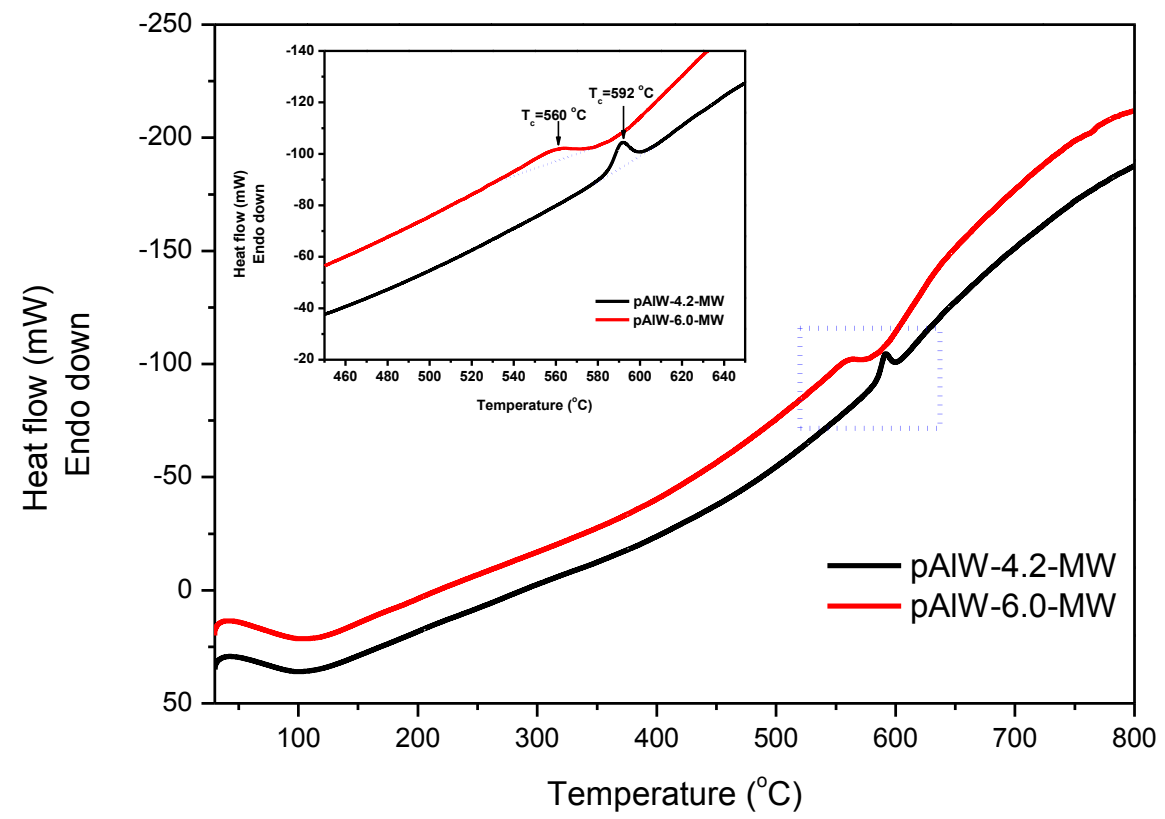

(b)

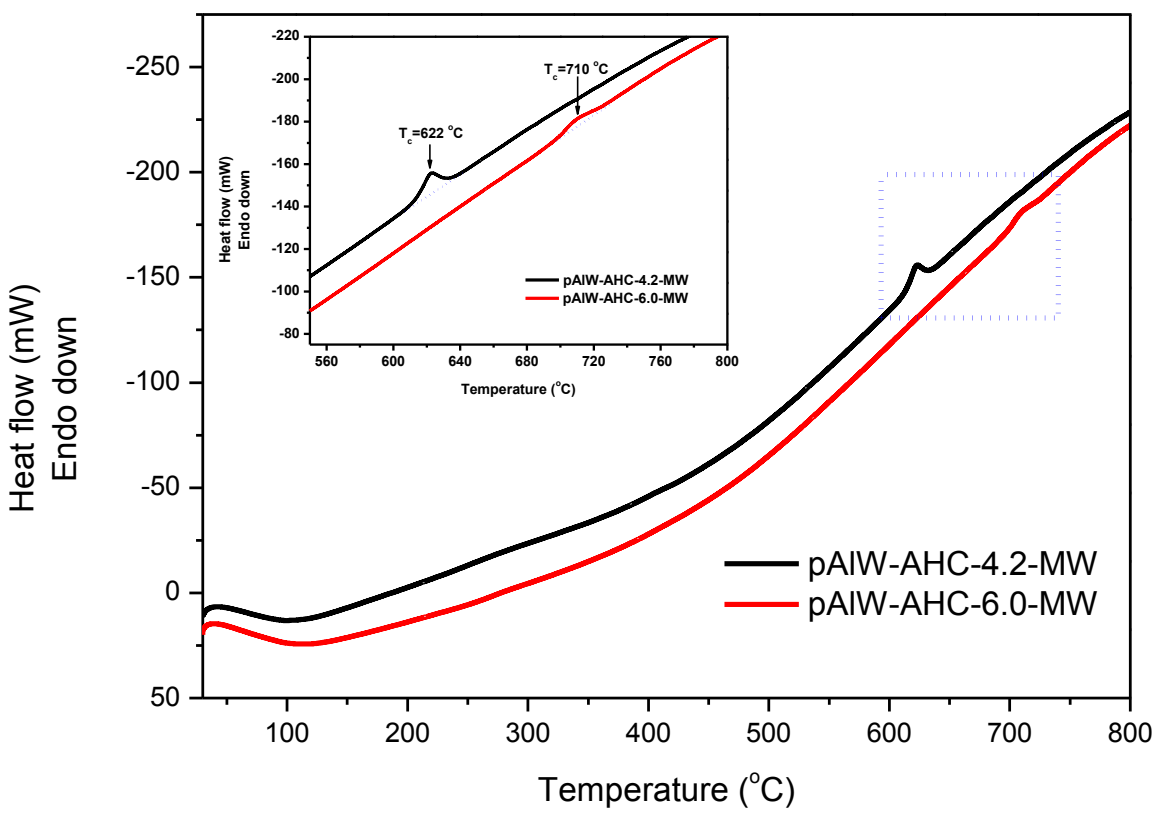

Figure B. 1- DSC curves of $\mathrm{Al}_{2} \mathrm{~W}_{3} \mathrm{O}_{12}$ microwave dried precursors, synthesized at $\mathrm{pH}=4.2$ and $\mathrm{pH}=6.0$ through (a) co-precipitation by mixing reactants and (b) normal strike coprecipitation. Insets show the crystallization peaks marked with arrows. 
Table B.1- CHN results of freshly precipitated $\mathrm{Al}_{2} \mathrm{~W}_{3} \mathrm{O}_{12}$ precursors without drying, synthesized by normal strike co-precipitation.

\begin{tabular}{cccc}
\hline Samples & $\begin{array}{c}\text { Nitrogen } \\
(\text { mass \%) }\end{array}$ & $\begin{array}{c}\text { Carbon } \\
\text { (mass \%) }\end{array}$ & $\begin{array}{c}\text { Hydrogen } \\
\text { (mass \%) }\end{array}$ \\
\hline pAlW-AHC-4-MW & 1.1 & 0.4 & 1.8 \\
pAlW-AHC-6-MW & 2.5 & 0.4 & 2.2 \\
\hline
\end{tabular}




\section{Appendix C: Supplementary material to support Chapter 6}

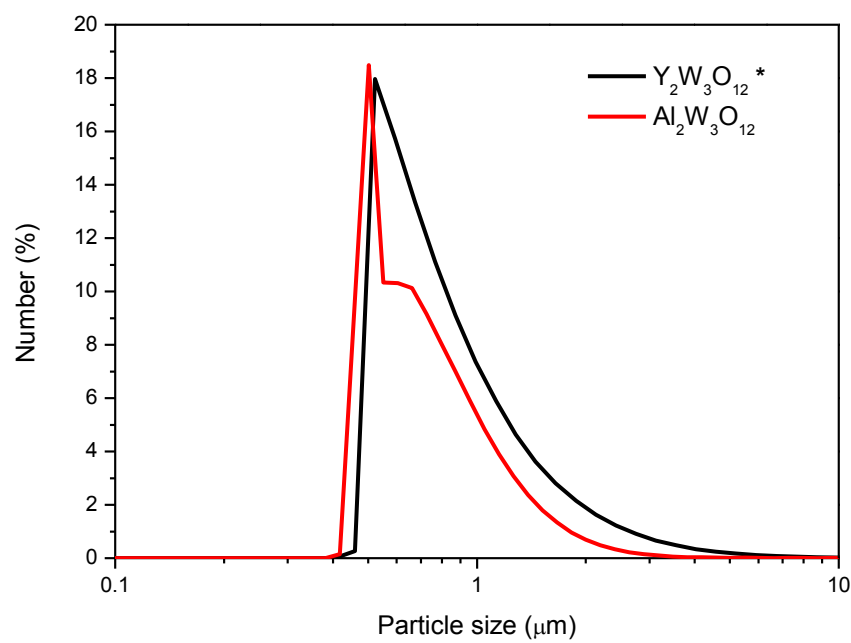

Figure C.1- Particle size distributions in number of $\mathrm{Al}_{2} \mathrm{~W}_{3} \mathrm{O}_{12}$ and $\mathrm{Y}_{2} \mathrm{~W}_{3} \mathrm{O}_{12}$ fillers obtained by laser diffraction. $\mathrm{Al}_{2} \mathrm{~W}_{3} \mathrm{O}_{12}$ was synthesized by normal strike method, $1 \mathrm{~h}$ of aging, calcination at $750{ }^{\circ} \mathrm{C}$ and ball milling during $98 \mathrm{~min} .{ }^{*} \mathrm{Y}_{2} \mathrm{~W}_{3} \mathrm{O}_{12}$ corresponds to sample $\mathrm{Y}_{2} \mathrm{~W}_{3} \mathrm{O}_{12}-\mathrm{B}$ reported by Pontón et al. [84].

Table C. 1- Crystallinity degree $\left(\mathrm{X}_{\mathrm{c}}\right)$ of HDPE and HDPE $/ \mathrm{Y}_{2} \mathrm{~W}_{3} \mathrm{O}_{12}$ composite specimens after being subjected to the second heating run in dilatometer.

\begin{tabular}{cccc}
\hline $\begin{array}{c}\text { Filler content } \\
(\text { vol. \%) }\end{array}$ & $\Delta \mathrm{H}^{*}\left(\mathrm{~J} \cdot \mathrm{g}^{-1}\right)$ & $\mathrm{X}_{\mathrm{c}}(\%)$ & $\begin{array}{c}\Delta \mathrm{X}_{\mathrm{c}}^{* *} \text { between first and } \\
\text { second heating }(\%)\end{array}$ \\
\hline \hline 0.0 & 147.8 & 50.4 & 8.2 \\
0.3 & 150.9 & 52.1 & 7.1 \\
0.6 & 163.2 & 57.2 & 9.2 \\
1.1 & 160.5 & 57.9 & 3.6
\end{tabular}

* Enthalpy change of melting measured by DSC. ${ }^{* *}$ Value computed as the difference between $\mathrm{X}_{\mathrm{c}}$ of specimens before first and after second heating cycle in dilatometer. $X_{c}$ values before first heating cycle are presented in paper in Table 6.8. 
(a)

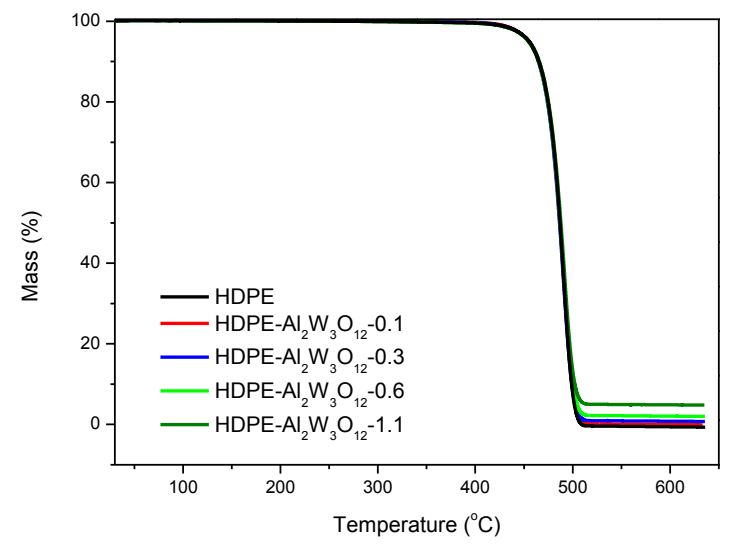

(b)

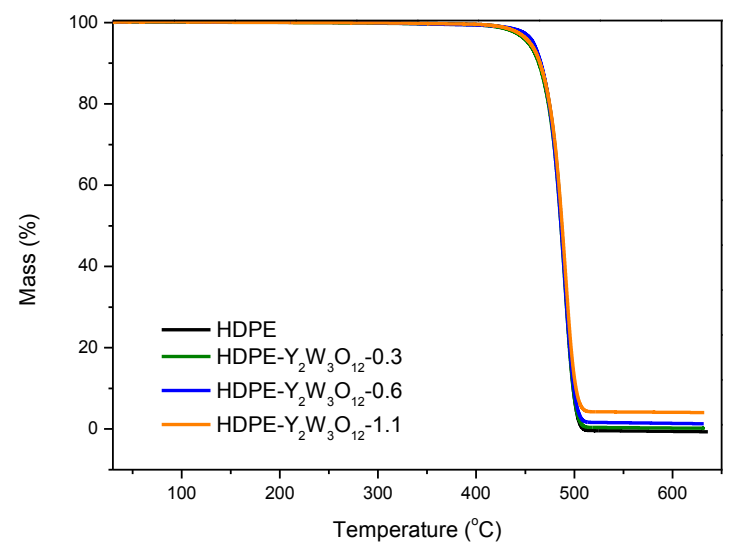

Figure C.2- TG curves of (a) HDPE/ $/ \mathrm{Al}_{2} \mathrm{~W}_{3} \mathrm{O}_{12}$ and (d) $\mathrm{HDPE} / \mathrm{Y}_{2} \mathrm{~W}_{3} \mathrm{O}_{12}$ composites.

(a)

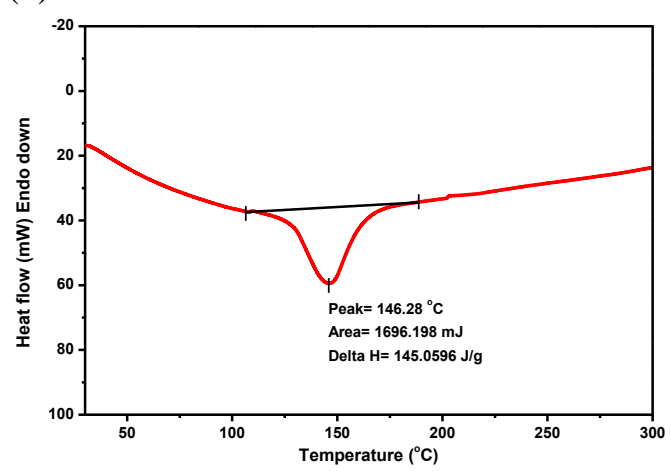

(c)

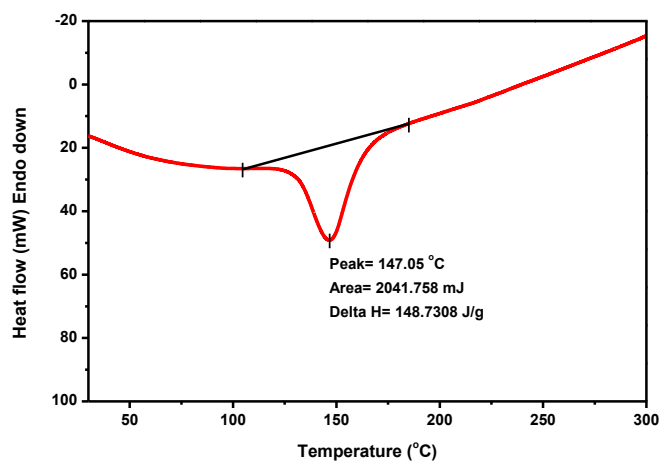

(b)

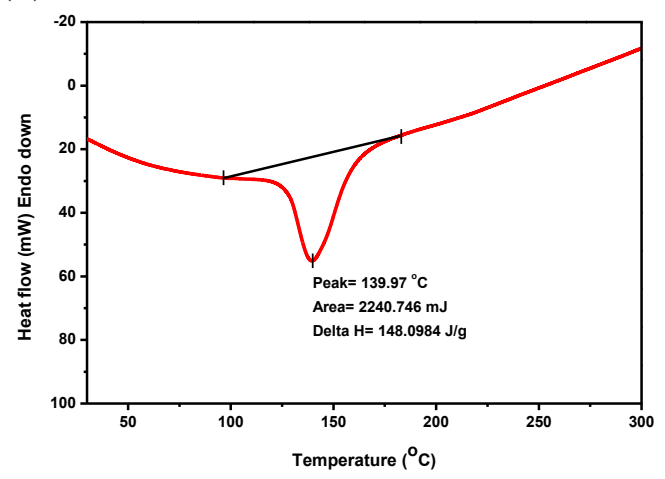

(d)

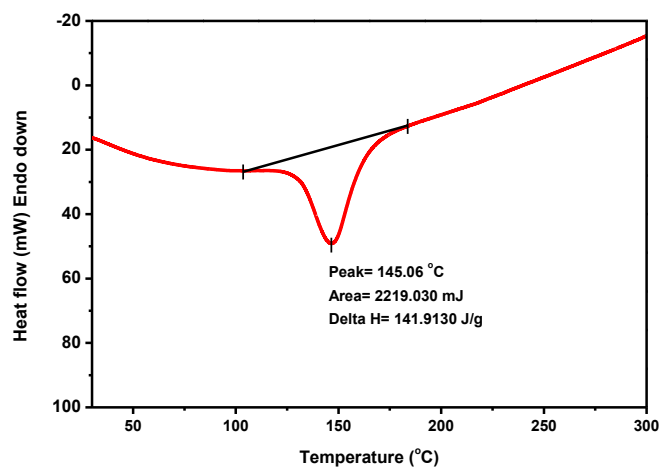

Figure C.3. DSC curves of (a) $\mathrm{HDPE} / \mathrm{Al}_{2} \mathrm{~W}_{3} \mathrm{O}_{12}-0.1$, (b) $\mathrm{HDPE} / \mathrm{Al}_{2} \mathrm{~W}_{3} \mathrm{O}_{12}-0.3$, (c) $\mathrm{HDPE} / \mathrm{Al}_{2} \mathrm{~W}_{3} \mathrm{O}_{12}-0.6$ and (d) $\mathrm{HDPE} / \mathrm{Al}_{2} \mathrm{~W}_{3} \mathrm{O}_{12}-1.1$ composites. 
(a)

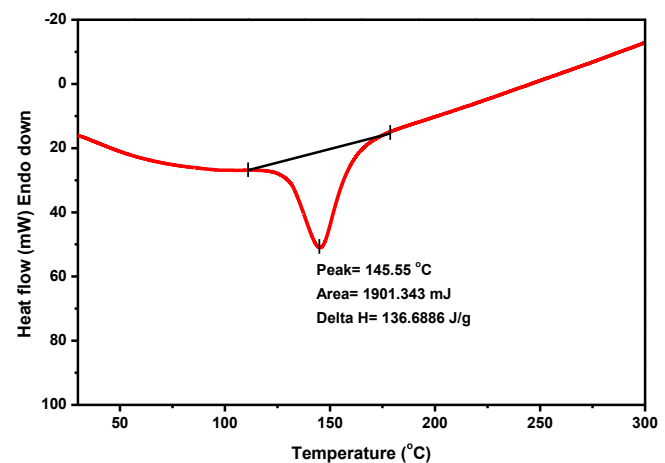

(c)

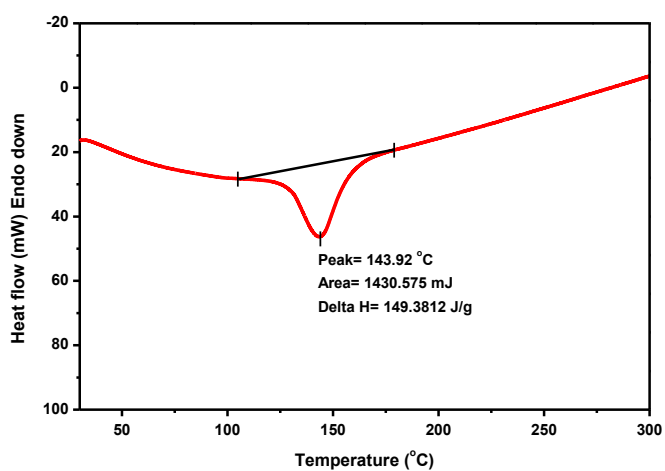

(b)

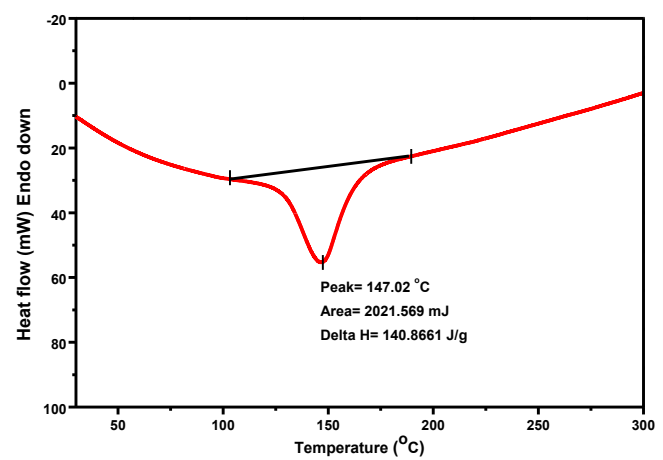

(d)

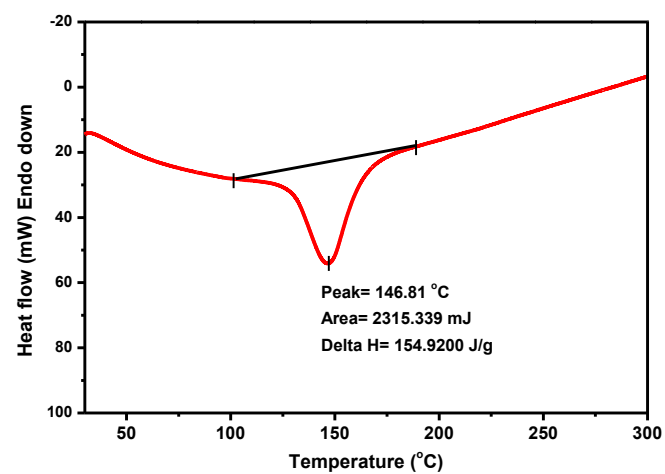

Figure C.4- DSC curves of (a) neat HDPE, (b) $\mathrm{HDPE} / \mathrm{Y}_{2} \mathrm{~W}_{3} \mathrm{O}_{12^{-}}-0.3$, (c) $\mathrm{HDPE} / \mathrm{Y}_{2} \mathrm{~W}_{3} \mathrm{O}_{12^{-}}$ 0.6 and (d) $\mathrm{HDPE} / \mathrm{Y}_{2} \mathrm{~W}_{3} \mathrm{O}_{12}-1.1$ composites.

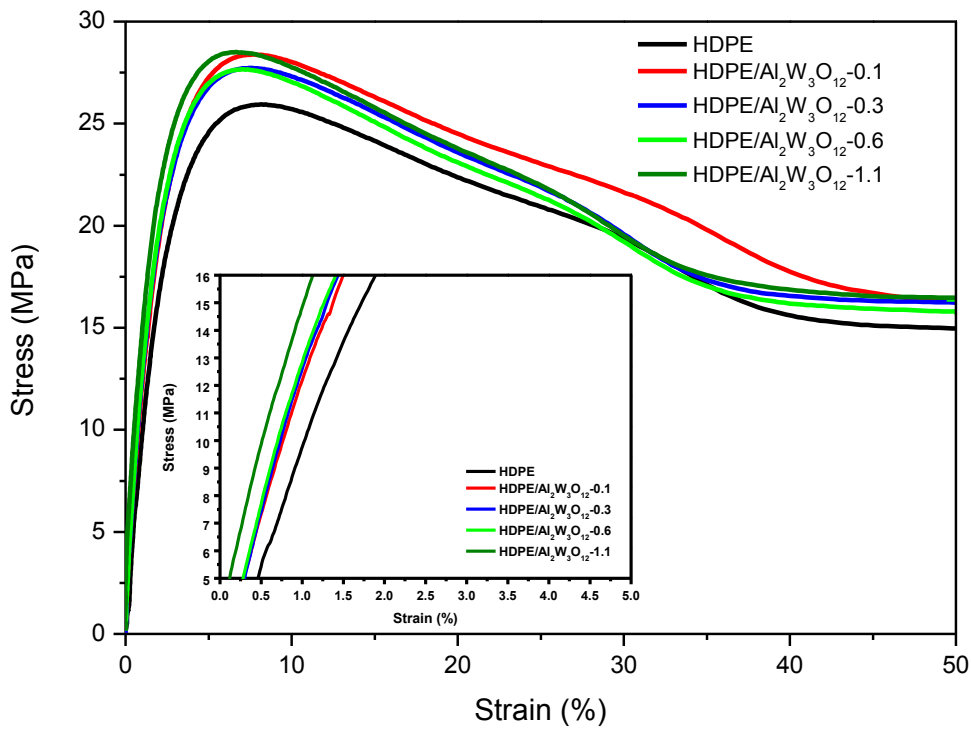

Figure C.5- $A$ region of stress-strain curve of $\mathrm{HDPE} / \mathrm{Al}_{2} \mathrm{~W}_{3} \mathrm{O}_{12}$ composites for different volume percentage of filler (Inset: Magnification view of stress-strain curve in the stress range of 5 to $16 \mathrm{MPa}$ ). 


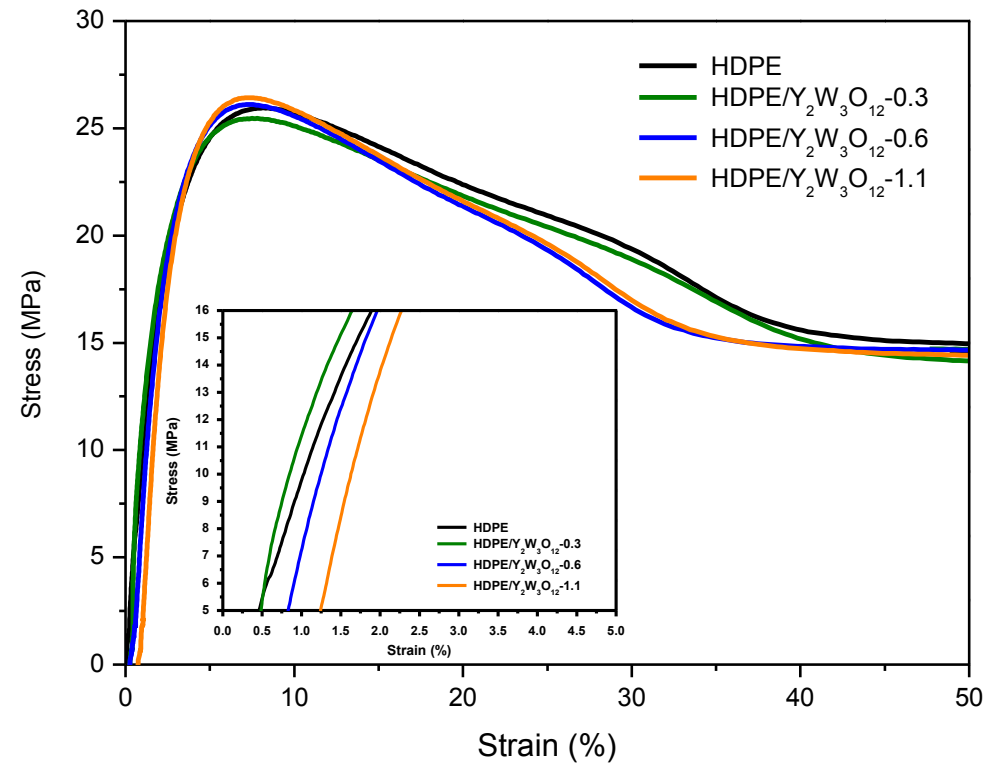

Figure C.6- $A$ region of stress-strain curve for $\mathrm{HDPE} / \mathrm{Y}_{2} \mathrm{~W}_{3} \mathrm{O}_{12}$ composites (Inset: magnification view of stress-strain curve in the stress range of 5 to $16 \mathrm{MPa}$ ). 